\title{
The Antiwilderness Bias in American Property Law
}

\author{
John G. Sprankling†
}

The American wilderness ${ }^{1}$ is dying. At the dawn of the nineteenth century, over 95 percent of the nation was pre-Columbian wilderness: ${ }^{2}$ forests, prairies, wetlands, deserts, and other lands in primeval condition, without any human imprint. Today, on the eve of the twenty-first century, wilderness remnants occupy between 10 and 20 percent of the country. ${ }^{3}$ After two hundred years of development, the United States is almost a postwilderness nation. ${ }^{4}$ As the legendary environmentalist Bob

$\dagger$ Professor of Law, McGeorge School of Law, University of the Pacific. B.A. 1972, University of California, Santa Barbara; J.D. 1976, University of California, Berkeley; J.S.M. 1984, Stanford University. I thank McGeorge School of Law and Dean Gerald Caplan for summer research funding for this Article. I also thank Christopher H. Doyle, Christopher M. Forrester, Julie L. Harlan, and Annie M. Rogaski for their excellent research assistance. Most importantly, I thank my wife Gail Heckemeyer whose encouragement and support made this Article possible.

1 This Article uses three somewhat different definitions of wilderness: (1) "preColumbian wilderness," meaning wilderness of the quality that existed before the European discovery of America (see note 34); (2) "statutory wilderness," meaning wilderness as defined under the Wilderness Act of 1964, 16 USC $\S 1131$ (c) (1994); and (3) "de facto wilderness," a term adapted from judicial usage, meaning any parcel of undeveloped land that appears to be substantially in natural condition with no significant human imprint. See text accompanying notes 217-20. Unless otherwise indicated by the context, wilderness, as used herein, refers to de facto wilderness.

2 See note 34 (explaining computation of 95 percent figure); see also Council on Environmental Quality, Environmental Quality: The Sixteenth Annual Report of the Council on Environmental Quality 32-33 (1985) ("16th CEQ Report") (generally discussing the extent of European settlement in North America in the late 1700s).

3 Using the "statutory wilderness" standard, less than 10 percent of the continental United States is occupied by wilderness. See Dave Foreman and Howie Wolke, The Big Outside: A Descriptive Inventory of the Big Wilderness Areas of the United States 20 (Harmony $2 d$ ed 1993). Under the broader "de facto wilderness" standard, this figure is increased to about 20 percent. See note 220.

- Justice Douglas, for example, mourned the development of "our dwindling wilderness." Life of the Land v Brinegar, 414 US 1052, 1055 (1973) (Douglas dissenting). See also Izaak Walton League of America $v$ St. Clair, 353 F Supp 698, 714 (D Minn 1973) ("As the United States was settled and frontiers vanished, wilderness disappeared except for inaccessible or otherwise then commercially useless areas. As of today but few true wilderness areas remain."); Kisner $v$ Butz, 350 F Supp 310, 326 (N D W Va 1972) ("[W]e continue to live in a world that slowly but certainly shrinks around us, with the surge of people surely and rapidly reaching back into hitherto untouched lands, leaving the mark of civilization upon wilderness areas ...."). 
Marshall lamented, "[t]he universe of the wilderness is disappearing like a snowbank on a south-facing slope on a warm June day. ${ }^{n 5}$

Does modern property law influence the destruction of privately owned wilderness? Although the question has never been explored, the conventional assumption appears to be a qualified "no." Property law is seen as essentially neutral, ${ }^{7}$ neither encouraging nor discouraging wilderness destruction, except in the limited sense of facilitating owner autonomy. ${ }^{8}$ The neutrality paradigm acknowledges that property law grants owners broad discretion to decide whether to destroy or preserve the natural condition of their wilderness lands. Thus, it attributes the disappearance of private wilderness to voluntary choice; an owner's decision to convert native grassland to a corn field, for example, reflects nothing more than the owner's exercise of free will.

This Article explores the relationship between privately owned wilderness land and American property law. Challenging the neutrality paradigm, it demonstrates that a nineteenthcentury antiwilderness bias still influences modern property law. All other things being equal, the property law system tends to resolve disputes by preferring wilderness destruction to wilderness preservation. ${ }^{9}$

5 Quoted in Foreman and Wolke, Big Outside at 1 (cited in note 3).

6 The Council on Environmental Quality, for example, assumes that American property law would enforce an owner's decision to preserve her wilderness land. Council on Environmental Quality, Environmental Quality: The Fifteenth Annual Report of the Council on Environmental Quality 367 (1984) ("15th CEQ Report") ("Because private property rights in the United States are relatively secure and extensive, private owners have the ability to protect their lands from over use.").

7 The neutrality paradigm is reflected in the common landowner expectation of unfettered freedom in land use decisions, absent conduct that interferes with the rights of others. See Joseph L. Sax, Why We Will Not (Should Not) Sell the Public Lands: Changing Conceptions of Private Property, 1983 Utah L Rev 313, 318; Lynton K. Caldwell, Rights of Ownership or Rights of Use?-The Need for a New Conceptual Basis for Land Use Policy, 15 Wm \& Mary L Rev 759, 761-62 (1974).

8 Owner autonomy is widely viewed as the heart of American property law. See, for example, David Farrier, Conserving Biodiversity on Private Land: Incentives for Management or Compensation for Lost Expectations?, 19 Harv Envir L Rev 303, 307-08 (1995); John A. Humbach, Law and a New Land Ethic, 74 Minn L Rev 339, 340 (1989); James P. Karp, A Private Property Duty of Stewardship: Changing Our Land Ethic, 23 Envir L 735, 759 (1993).

9 I suggested in a prior article that the adverse possession doctrine was oriented against the existence of undeveloped land. John G. Sprankling, An Environmental Critique of Adverse Possession, 79 Cornell L Rev 816, 840-53 (1994). In the present Article I develop the thesis that a general antiwilderness bias pervades the American property law system. 
Part I develops the thesis that the abundance of wilderness land in the young United States substantially affected the nineteenth-century evolution of American property law. This "wilderness thesis" argues that an instrumentalist judiciary modified English property law to encourage the agrarian development, and thus destruction, of privately owned American wilderness. Six illustrative doctrines-waste, adverse possession, possession as notice to a bona fide purchaser, good faith improver, trespass, and nuisance-reflect this early antiwilderness retooling.

Part II demonstrates that contemporary property law remains tilted toward wilderness destruction, as exemplified by the modern versions of the same six doctrines. Today, an increasing number of owners confronting the historic decline of American wilderness elect to retain their lands in natural condition. However, the entrenched antiwilderness bias of the property law system-which has already influenced the destruction of millions of wilderness acres-threatens their preservation efforts.

Finally, Part III proposes the prowilderness reform of American property law. Property rules crafted in an age of wilderness abundance are ill-suited to today's age of wilderness scarcity. A neoinstrumentalist judiciary must again retool basic doctrines to redress this historic imbalance. The new equilibrium that results will ensure that the property law system of the twenty-first century facilitates the voluntary preservation of privately owned wilderness.

\section{WILDERNESS AND THE BIRTH OF AMERICAN PROPERTY LAW}

\section{A. The Wilderness Thesis}

American property law was born in the early nineteenth century as judges retooled English property law doctrines to meet the conditions in the new United States. ${ }^{10}$ In part, this transition reflected the broad jurisprudential shift from formalism to instrumentalism, recounted by Willard Hurst ${ }^{11}$ and others, ${ }^{12}$ which affected the entire legal system. While their eigh-

${ }^{10}$ See Grant Gilmore, The Ages of American Law 8 (Yale 1977) ("[I]t is pointless to speak of an 'American law' before the 1800s."). See also text accompanying notes 82-197.

1 See James Willard Hurst, Law and the Conditions of Freedom in the Nineteenth Century United States (Wisconsin 1956).

12 See, for example, Morton J. Horwitz, The Transformation of American Law, 17801860 (Harvard 1977) (analyzing the development of early American law from the instrumentalist perspective); Harry N. Scheiber, Instrumentalism and Property Rights: A Reconsideration of American "Styles of Judicial Reasoning" in the 19th Century, 1975 Wis L Rev 
teenth-century counterparts had typically adhered to English precedents, ${ }^{13}$ nineteenth-century American judges awakened to the reality that common law could further economic development and began to create a uniquely American jurisprudence.

The scant instrumentalist scholarship examining the early evolution of our property law consistently overlooks a central factor in this process: the American wilderness. ${ }^{14}$ Legal scholars

\section{1, 12-18 (describing the rise of instrumentalism in the context of property rights).}

${ }_{13}$ During the seventeenth and eighteenth centuries, colonial American property law evolved from a collection of informal, isolated, and inconsistent doctrinal fragments into a system that approximated English law. The seventeenth century saw the development of indigenous doctrines suited to American conditions. As formalized judicial systems emerged in the eighteenth century, however, the English common law of property slowly eclipsed this incipient American approach. The American success of Blackstone's Commentaries on the Laws of England symbolized the triumph of English law. First published in America in 1771-72, this eminently readable summary of English common law quickly became the most popular legal treatise in the colonies. See Lawrence M. Friedman, $A$ History of American Law 112 (Simon \& Schuster 2d ed 1985). Blackstone's view of property was particularly influential. In defining property as "that sole and despotic dominion which one man claims and exercises over the external things of the world, in total exclusion of the right of any other individual in the universe," he expressed a reverence for private property rights well suited to American opinion, which increasingly embraced property law as a shield against royal power. J.W. Ehrlich, ed, Ehrlich's Blackstone 113 (Nourse 1959).

Although 1776 brought political independence, American law remained dependent on English jurisprudence. Citations to English cases and treatises dominated the American law reports for the remainder of the eighteenth century. For example, a review of Daniel Boorstin's landmark study of early Delaware decisions found that cases decided between 1792 and 1800 showed "few traces of having been moulded by local conditions." Zechariah Chafee, Jr., Delaware Cases, 1792-1800, in David H. Flaherty, ed, Essays in the History of American Law 489, 507 (North Carolina 1969). Chafee noted that Delaware courts cited primarily to English decisions, relying upon their own precedent "much less often." Id at 503-04. Even a casual examination of other state reports from the late eighteenth century confirms that this was true throughout the new nation. Compare Friedman, History of American Law at 109 ("English authorities flooded the country.").

${ }_{14}$ Hurst and his disciples largely ignore the early evolution of the common law of property, aside from minor explorations by Lawrence Friedman and Morton Horwitz. See Friedman, History of American Law at 234-45 (cited in note 13); Horwitz, Transformation of American Law at 31-62 (cited in note 12). Moreover, even Friedman and Horwitz fail to appreciate the impact of American wilderness conditions on this process, partly because neither focuses on agricultural development, by far the most common form of productive land use in the young United States. See Thomas R. Cox, et al, This Well-Wooded Land: Americans and Their Forests from Colonial Times to the Present 103 (Nebraska 1985) (observing that by 1860 , over 153 million acres had been cleared for agriculture in the United States, "over twelve times the amount cleared as a result of industrial, lumbering, mining, and urban development") (emphasis added). Horwitz primarily explores how the property law system changed to facilitate industrial development, notably in the context of mills, dams, and other structures. In so doing, he argues that the "idea of property underwent a fundamental transformation-from a static agrarian conception ... to a dynamic, instrumental, and more abstract view of property ...." Horwitz, Transformation of American Law at 31. Friedman, on the other hand, focuses on legal changes encouraging the free alienation of property, likewise arguing that the "agrarian concep- 
agree that nineteenth-century American courts adopted English common law in general only to the extent consistent with American conditions; but the particular conditions which influenced the reception of English property law have received little academic attention. ${ }^{15}$

I propose a "wilderness thesis": Our common law of property is best explained as an instrumentalist adaptation of English doctrines to American wilderness conditions. ${ }^{16}$ It is axiomatic that geography influences law; ${ }^{17}$ this precept applies particularly to property law, which regulates rights and duties concerning land. Nineteenth-century judges, faced with the task of fashioning a body of property law that would encourage national development, were forced to confront the physical nature of the American landscape-rugged terrain, dense forest, tangled vegetation, arid plains, and lush wetlands. From this perspective, the wilderness was an obstacle to progress.

Eighteenth-century English property law was a poor tool for encouraging the exploitation of virgin land. The vast English

tion" of property was abandoned. Friedman, History of American Law at 235-36, quoting Horwitz, Transformation of American Law at 30.

${ }^{15}$ For example, Richard Powell observes that "legal historians have scarcely scratched the surface of needed inquiries into the beginnings of American land law." Richard R. Powell, 1 Powell on Real Property II 35 at 75 (Matthew Bender 1995). Early American property law mainly resides in musty, poorly organized state reports, a universe which one commentator termed "the wasteland of American legal history." Leonard W. Levy, The Law of the Commonwealth and Chief Justice Shaw 3 (Harper 1967).

16 I acknowledge inspiration from Frederick Jackson Turner's focus on the importance of the frontier on American society in general. Advanced in an 1893 essay, Turner's "frontier thesis" posited that the American character and the "peculiarity of American institutions" in general stemmed from "the fact that [Americans] have been compelled to adapt themselves to the changes of an expanding people-to the changes involved in crossing a continent, in winning a wilderness, and in developing at each area of this progress out of the primitive economic and political conditions of the frontier into the complexity of city life." Frederick Jackson Turner, The Significance of the Frontier in American History, in Ray Allen Billington, ed, The Frontier Thesis: Valid Interpretation of American History? 9, 9-10 (Holt, Rinehart \& Winston 1966). Turner essentially overlooked the influence of the frontier upon law, aside from generally suggesting that in the West social customs evolved into law. Frederick Jackson Turner, The Frontier in American History, in Ray Allen Billington, ed, The Frontier Thesis: Valid Interpretation of American History? 21, 22-24 (Holt, Rinehart \& Winston 1966). I disagree, moreover, with this suggestion in the context of real property law. Based on my research, I conclude that the early evolution of American property law was primarily the product of an instrumentalist judiciary, not the evolution of social customs into legal rules. See Part I.C.

${ }^{17}$ See, for example, Charles de Secondat, Baron de Montesquieu, The Spirit of Laws, reprinted in Robert Maynard Hutchins, ed, 38 Great Books of the Western World 125-34 (Encyclopedia Britannica 1952) (discussing the relationship between law and the "nature of the soil"). Nonetheless, modern legal scholars have by and large neglected the relationship between law and geography. A notable exception to this lacuna is Bernhard Grossfeld, Geography and Law, 82 Mich L Rev 1510 (1984). 
wilderness had vanished long before the discovery of America, ${ }^{18}$ leaving a semipreservationist property law system $^{19}$ attuned to a postwilderness nation. Most of the English countryside resembled a large garden, ${ }^{20}$ with crop land and permanent grass pasture occupying over half of the land surface; $;^{21}$ the forest remnants were uniformly devoted to human use, as woodlot, pasture, or the like. ${ }^{22}$ The property law system focused on preserving the condi-

${ }^{18}$ Six thousand years ago, England was a vast wilderness governed by the forces of nature. Forest occupied about two-thirds of the land surface, while marshes, moors, and mountains dominated the balance. Robin H. Best, Land Use and Living Space 10 (Methuen 1981). See also Stuart Piggott, ed, 1 The Agrarian History of England and Wales 9-23 (Cambridge 1981) (discussing the English landscape before 4000 B.C.). However, as the Domesday Book recounts, most English wilderness had vanished by 1086 A.D. See Henry C. Darby, ed, A New Historical Geography of England 47-62 (Cambridge 1973) (discussing the geographical components of the Domesday Book). Five thousand years of agricultural development, accelerated by waves of Roman and Anglo-Saxon colonization, had transformed the landscape. See Best, Land Use at 11-13. Due to persistent forest cutting, by 1696 only 15 percent of England could still be considered wooded, id at 14 table 4 , and most of these remnants had been placed in human use as woodlot, pasture, or the like. See Oliver Rackham, Trees and Woodland in the British Landscape 55-56 (Dent 2d ed 1976). See also Darby, ed, New Historical Geography at 54 (mapping the English woodlands remaining as of 1086 ).

19 Although not overtly oriented toward preservation, the English common law of property tended to produce this effect. All other things being equal, it tended to resolve land-use disputes by perpetuating existing, low-intensity uses of land at the expense of new, high-intensity uses. This semipreservationist orientation was reflected in an absolutist approach to defining the content of property rights. $O$, the paradigmatic property owner of the era, enjoyed virtually complete autonomy to continue existing activities on his land. Yet the ability of third parties to assert their own absolutist rights against $O$ - under doctrines such as waste and nuisance-tended to deter $O$ from undertaking more intense development. See text accompanying notes $82-92,184-85$, and 192 . This conflict of "absolute" rights resulted in stalemate, and thus perpetuation of the status quo.

20 Despite the preponderance of crop land, pasture, and woodlot, by 1800 undeveloped moors, mountains, and other "rough grazings" still composed about 26 percent of the English land surface. See Best, Land Use at 14 table 4 (cited in note 18). Most of this land, however, had been placed in economic use for sheep grazing, and could no longer be considered wild. See Darby, ed, New Historical Geography at 421 (cited in note 18) (noting that by 1800 , "most of the rough grazing land [ ] was devoted to feeding sheep").

${ }^{21}$ See Best, Land Use at 14 table 4 (cited in note 18); see also Darby, ed, New Historical Geography at 313-27 (cited in note 18) (discussing generally the impacts of the enclosure movement, new crop varieties, and new fertilizers on the extension of English agxiculture in the seventeenth and eighteenth centuries).

${ }_{22}$ See Rackham, Trees and Woodland at 39-57 (cited in note 18). Rackham explains that as early as 1086, every woodland in England belonged to a specific owner and was in economic use, with the possible exception of the Forest of Dean, which he concludes was converted to human use no later than 1250 . By 1250, then, no virgin forest existed in England. Id at 55. By the early seventeenth century, industrial and naval demands for wood had encouraged the devastation of the remaining woodlands, despite royal and parliamentary efforts to mandate conservation and encourage reforestation. Legal efforts to slow the deforestation of sixteenth- and seventeenth-century England are chronicled in John Perlin, A Forest Journey: The Role of Wood in the Development of Civilization 163227 (Norton 1989). 
tion of land already in productive use in a mature agrarian economy, not on expanding an inchoate economy through the settlement of wild land. ${ }^{23}$ Moreover, in an England plagued by a chronic wood shortage, ${ }^{24}$ the system was already oriented toward protection of the nation's dwindling forests. ${ }^{25}$ Stability, not innovation, was the heart of English property law. ${ }^{26}$

As the nineteenth century unfolded, American courts slowly remolded English property law doctrines to meet the challenges of a wilderness nation. The analysis below supports this wilderness thesis at two levels. First, many early American property law opinions ${ }^{27}$ justify the modification of traditional rules as necessary to adapt English law to American wilderness conditions. Justice Story summarized the sentiment of the era in an 1829 Supreme Court decision: "The country was a wilderness,

23 For example, any significant change in the existing character of land, such as converting meadow to crop land, was considered waste, even if the value of the land was thereby increased. See Ehrlich, ed, Ehrlich's Blackstone at 291 (cited in note 13) ("The conversion of land from one species to another is waste. To convert wood, meadow, or pasture into arable ... [is] waste."). See also Jackson v Brownson, 7 Johns 227, 229-37 (NY 1810) (discussing English law of waste); Hastings $v$ Crunckleton, 3 Yeates 261, 261-62 ( $\mathrm{Pa} 1801$ ) (same). Suppose $A$, holding a life estate in ten acres of meadow, cleared the land and planted wheat; even though this would increase the market value of the land, $B$, the remainderman, could still sue $A$ in waste. In theory, $B$ might be able to both terminate $A$ 's life estate and obtain treble damages, although by the eighteenth century, the normal remedy for waste was injunctive relief or actual damages. See Richard $R$. Powell, 5 Powell on Real Property II 637 at 56-8 to 56-9 (Matthew Bender 1994). By equating new land uses with unlawful waste, the English property law system tended to maintain the status quo at the expense of new development. The expansive definition of nuisance similarly tended to restrain development. See text accompanying notes 184-85.

${ }^{24}$ See Perlin, Forest Journey at 191-227 (cited in note 22). A 1662 report on the condition of seven Royal Forests, for example, concluded that they were "for the most part without trees." Id at 214. A woodland tract as small as one hundred acres was considered a major forest. See Cox, et al, Well-Wooded Land at 12 (cited in note 14).

${ }^{25}$ Concern for dwindling woodlands led to the first conservation statutes in England. As early as 1613, King James I decreed that "timber" trees-oak, ash, elm, and other trees suitable for building-could not be used as firewood. See Perlin, Forest Journey at 193 (cited in note 22). This conservationist impetus led to British statutes that restricted tree cutting in the American colonies to preserve trees suitable for masts and other naval stores. See Samuel F. Manning, New England Masts and the King's Broad Arrow 25-33 (Murphy 1979).

${ }^{25}$ As Morton Horwitz describes it, the English view of property-which colonial America inherited-was a "static agrarian conception." See Horwitz, Transformation of American Law at 31 (cited in note 12).

${ }^{27}$ The use of appellate opinions as grist for historical analysis poses obvious risks. See generally G. Edward White, The Appellate Opinion as Historical Source Material, I J Interdiscip Hist 491 (1971) (discussing potential problems with reliance on appellate opinions as source materials). Nevertheless, this Article assumes that statements in appellate decisions are intended as accurate by their authors. 
and the universal policy was, to procure its cultivation and improvement."28

Second, the substance of these nineteenth-century modifications reflects a system logically designed to encourage the development of the American wilderness. For example, the doctrine of waste - the key English limitation on unfettered land use applicable to co-owners-was narrowed for wild land. ${ }^{29}$ Similarly, doctrines governing title-such as adverse possession and the rule that possession provides constructive notice to a subsequent purchaser-were adjusted for wilderness land in a manner that tended to vest title in the industrious user rather than the idle claimant. $^{30}$ Enhancement of the legal protection afforded the mistaken improver of another's land provided yet another incentive to develop wilderness. ${ }^{31}$ Finally, the traditional rules regulating land use by neighboring owners-trespass and nuisance-were altered to promote the use of wilderness land. ${ }^{32}$

In effect, early American courts constructed a new property law system with an inherent antiwilderness bias. All other things being equal, the reformulated common law of property tended to resolve use and title disputes in favor of the wilderness exploiter and against the wilderness nonuser. This judicial thumb unbalanced the scales of justice for the next two centuries.

\section{B. Wilderness in Early America}

The United States was a wilderness nation when the nineteenth century dawned. ${ }^{33}$ Forests, grasslands, wetlands, deserts, and other lands unaffected by human activity-in the same primeval condition which preceded the European discovery of America-covered almost the entire land surface. ${ }^{34}$ The scant

28 Van Ness $v$ Pacard, 27 US (2 Pet) 137, 145 (1829).

29 See text accompanying notes 93-104.

30 See text accompanying notes 113-18 and 130-41.

32 See text accompanying notes 147-57.

32 See text accompanying notes 163-83 and 187-97.

33 The overwhelming wilderness character of the early United States is evidenced by the personal observations of early explorers and travelers. See, for example, notes 37-39 and accompanying text.

${ }^{34}$ In 1492, the conventional date for the European discovery of America, almost the entire land surface of the future United States was wilderness. See Roderick Nash, Wilderness and the American Mind 7 (Yale 3d ed 1982) (observing that "[t]he New World was [ ] wilderness at the time of discovery because Europeans considered it such."). By the late 1700 s, roughly 120,000 square miles of land along the Atlantic Coast, approximately 4 percent of the total land surface of the modern continental United States, had been settled by Europeans. See 16th CEQ Report at 32 (cited in note 2) (noting Europeans had 
nonwilderness lands were clustered along the Atlantic coastal strip.

Colonial development concentrated along the coast due to a British policy restricting settlement west of the Allegheny Mountains. ${ }^{35}$ By 1776, a one-hundred-mile-wide strip, stretching from Maine to Georgia, had been partly cleared and placed in agricultural use. ${ }^{36}$ Even this semideveloped region, however, was heavily forested. Travelers visiting the United States after independence described Virginia as "an immense forest, ... almost without bounds" and New York as "nothing but one vast forest." ${ }^{38}$ As late as 1796 , a visitor was able to comment that, despite extensive journeys in the new nation, he had "scarcely passed, for three miles together, through a track of unwooded or cleared land." ${ }^{39}$

The balance of the United States was a huge tract of sparsely populated, publicly owned, pre-Columbian wilderness extending from the Allegheny Mountains west to the Mississippi River. ${ }^{40}$ A French naturalist who traveled through portions of this

settled a "100-mile-wide strip" from southern Maine to Georgia, a distance of approximately 1200 miles). In addition, by 1800 , Europeans had settled in other areas, notably in portions of what are now Kentucky, Tennessee, Louisiana, Arizona, California, New Mexico, and Texas; these settlements occupied less than 1 percent of the land surface. See id at 33 fig 2-1. If roughly 5 percent of the United States was settled in 1800 , then about 95 percent of the pre-Columbian wilderness remained untouched.

Although this Article focuses on the destruction of wilderness by European settlers, Native Americans undoubtedly affected wilderness conditions. William Cronon, for example, has explored the impact of Native Americans on the ecology of New England:

Selective Indian burning [ ] promoted the mosaic quality of New England ecosystems, creating forests in many different states of ecological succession. In particular, regular fires promoted what ecologists call the "edge effect." By encouraging the growth of extensive regions which resembled the boundary areas between forests and grasslands, Indians created ideal habitats for a host of wildlife species.

William Cronon, Changes in the Land: Indians, Colonists, and the Ecology of New England 51 (Hill \& Wang 1983).

${ }^{35} 16$ th $C E Q$ Report at 32 (cited in note 2).

${ }^{36}$ Id. It is estimated that as much as 90 percent of the Atlantic coastal strip settled by English colonists was originally forested. Cox, et al, Well-Wooded Land at 3 (cited in note 14).

37 John F.D. Smyth, 1 A Tour in the United States of America 36 (Robinson 1784).

${ }^{33}$ This quotation is attributed to Alexis de Tocqueville. George W. Pierson, Tocqueville and Beaumont in America 190 (Oxford 1938). Tocqueville's traveling companion, Gustave Beaumont, similarly concluded "the whole country is but a forest." Id at 193.

${ }^{39}$ C.F. Volney, A View of the Soil and Climate of the United States of America 6 (Conrad 1804) (C.B. Brown, trans).

${ }^{40}$ See 16th CEQ Report at 33 fig 2-1 (cited in note 2). Although both the federal government and certain states originally claimed title to these western lands, by 1802 the states had all relinquished their claims to the federal government. See Paul W. Gates, 
region-including Kentucky, Indiana, Illinois, and Michigan-in the late eighteenth century observed that "the most striking feature of America is the rugged and dreary prospect of an almost universal forest." ${ }^{31}$ Occasional meadows, ${ }^{42}$ wetlands, and small prairies ${ }^{43}$ supplemented the dominant forest.

Eighteenth-century federal policy helped to preserve this wilderness by retarding settlement of the western lands. Despite the insistence of Thomas Jefferson ${ }^{44}$ and others ${ }^{45}$ that vacant public lands should be freely granted to settlers in order to facilitate national expansion, the government initially envisioned these lands as a revenue source; proceeds from land sales could be used to finance current operations and repay the troublesome national debt. ${ }^{46}$ Accordingly, in 1783, the federal government prohibited squatting on the western lands. ${ }^{47}$ Although difficult to enforce, this edict presumably deterred settlement to some extent. ${ }^{48}$ Two years later, using the framework established by the Land Ordinance of 1785, the government embarked on the process of selling these lands. ${ }^{49}$ However, because parcels could be purchased only for cash, the rate of sale-and thus the pace of settlement-was slow. ${ }^{50}$

History of Public Land Law Development 51-57 (US GPO 1968).

41 Volney, View of the Soil at 6 (cited in note 39). The nature and extent of the American wilderness west of the Appalachian Mountains, as chronicled by early explorers, is described in a number of useful sources, including John Bakeless, The Eyes of Discovery: The Pageant of North America as Seen by the First Explorers (Lippincott 1950); Bill Lawrence, The Early American Wilderness: As the Explorers Saw It (Paragon House 1991); Rutherford Platt, Wilderness: The Discovery of a Continent of Wonder (Dodd, Mead 1961); and Carl O. Sauer, Seventeenth Century North America (Turtle Island 1980).

42 Meadows could be found even in largely forested Ohio. See Bakeless, Eyes of Discovery at 304 (cited in note 41).

${ }^{43}$ For a description of the wild prairies east of the Mississippi, see id at 315-16.

4t See Gates, Public Land Law at 62 (cited in note 40) (discussing Jefferson's opposition to the sale of the public lands).

${ }_{45}$ See Benjamin Horace Hibbard, A History of the Public Land Policies 2 (Peter Smith 1924) (noting others with views similar to Jefferson's position).

${ }^{46}$ See Gates, Public Land Law at 61-63 (cited in note 40). See also Jackson v Clark, 26 US (1 Pet) 628, 635 (1828) ("A heavy foreign and domestic debt, part of the price paid for independence, pressed upon the government; and the vacant lands constituted the only certain fund for its discharge.").

47 See Gates, Public Land Law at 67 (cited in note 40).

48 Id at 67-68, 219-21.

49 Land Ordinance of 1785, reprinted in Clarence E. Carter, ed, 2 The Territorial Papers of the United States 12-18 (US GPO 1934).

so See Gates, Public Land Law at 69-71 (cited in note 40). See also Hibbard, Public Land Policies at 41-42 (cited in note 45) (discussing the slow pace of public land sales after 1785). The federal government began inching toward a credit system as early as 1787 , allowing purchasers to make a cash down payment of one-third of the purchase price and pay the balance in three months. Id at 41 . 
The Louisiana Purchase of 1803 doubled the size of the United States ${ }^{51}$ by adding a vast, pristine wilderness situated roughly between the Mississippi River and the Rocky Mountains. ${ }^{52} \mathrm{Al}-$ though it was partially forested, ${ }^{53}$ the bulk of this land consisted of the prairie grasslands of the Great Plains. ${ }^{54}$ The purchase of these boundless prairies added an entirely new type of wilderness to the nation-level, fertile, and treeless, yet teeming with wildlife. ${ }^{55}$ Commissioned by President Jefferson to explore the Louisiana Territory with Meriwether Lewis in 1804, William Clark described a representative Nebraska prairie as "[c]overed with Grass 10 or 12 inches in hight [sic] . . Soil of good quallity [sic] . . . one Continual Plain as fur [sic] as Can be Seen." ${ }^{256}$

The overall nineteenth-century federal policy was to transfer this huge publicly owned American wilderness ${ }^{57}$ to private own-

51 Everett Somerville Brown, The Constitutional History of the Louisiana Purchase 1803-1812 1-2 (Kelley 1920). The Louisiana Purchase directly added 523,446,400 acres to the United States. See Gates, Public Land Law at 77 (cited in note 40).

${ }^{52}$ See 16th CEQ Report at 34 fig 2-2 (cited in note 2). For a general description of the American wilderness west of the Mississippi River, as seen by early explorers, see Bakeless, Eyes of Discovery at 344-406 (cited in note 41).

53 Most of the territory that now comprises the states of Arkansas, Louisiana, and Missouri was forested. See Perlin, Forest Journey at 264-65 (cited in note 22). See also Morrow $v$ White, 12 Ark App 16, 670 SW2d 459, 461 (1984) (noting that at the time of the Louisiana Purchase, Arkansas was a "vast wilderness").

st See Perlin, Forest Journey at 264-65 (cited in note 22). In 1803, the Great Plains remained, by and large, in the same condition in which Francisco Vásquez de Coronado, the earliest European explorer to visit the area, found them in 1541. Upon reaching what is now Kansas, Coronado encountered a land with "no landmarks, no streams, no mountains, no trees, no bushes, not even stones, for the deep, grass-grown prairie soil covered everything. As far as the strangers could see, there was only a flat expanse of grass, studded with buffalo bones, stretching illimitably away until it met the sky in a huge ring that closed the white men in." Bakeless, Eyes of Discovery at 93-94 (cited in note 41).

${ }_{s 5}$ See, for example, Bakeless, Eyes of Discovery at 353-54 (cited in note 41) (recounting the report of an 1835 visitor to the Platte River region, who found "an unbounded prairie, a broad river, with innumerable herds of buffalo grazing upon its banks, and occasionally a solitary tree standing in bold relief").

${ }_{56}$ Gary E. Moulton, ed, 2 The Journals of the Lewis and Clark Expedition 429-30 (Nebraska 1986). These descriptions of the Great Plains reflect a certain monotony. Thus, South Dakota regions were "a rich level plain ... fertile but without timber," "open and fertile plains and meadows ... rarely an instance of a tree to be seen," and "fertile and level plains and meadows, almost entirely destitu[t]e of timber." Gary E. Moulton, ed, 3 The Journals of the Lewis and Clark Expedition 359-61 (Nebraska 1987). The North Dakota landscape was described as "extensive, level and fertile, plains and meadows, in which scarsely [sic] a tree is to be seen" and "open plains and meadows, generally fertile, and always untimbered." Id at 361-62. Even eastern Montana offered only "a few scattering small scrubby pine and dwarf cedar on the summits of some of the highest hills, nine tenths of the country being wholy [sic] destitute of timber of any kind, covered with a short grass, arromatic [sic] herbs and the prickley [sic] pear." Gary E. Moulton, ed, 4 The Journals of the Lewis and Clark Expedition 170 (Nebraska 1987).

57 Territorial acquisitions after the Louisiana Purchase-particularly the 1845 annex- 
ers. ${ }^{58}$ By the beginning of the century, the goal of promoting rapid development had already displaced the desire to enhance revenues as the cornerstone of federal policy toward this land. ${ }^{59}$ The shift from cash transactions to a credit purchase system in 1800 accelerated sales. ${ }^{60}$ Thereafter, a series of gradual steps-including abandonment of the prohibition on squatting, recognition of squatters' preemptive purchase rights, and distribution of land bounties to certain military veterans - encouraged settlement. ${ }^{61}$ Jefferson's dream of free land distribution was ultimately realized with the passage of the Homestead Act of $1862 .{ }^{62}$ The public lands best suited for farming or ranching-given location, topography, water, soils, and other factors-were preferred, and thus transferred first. ${ }^{63}$ Holding title to these wilderness lands, pioneer settlers destroyed forests, denuded prairies, drained wetlands, and plowed deserts as the century proceeded.

\section{The Evolution of an Antiwilderness Property Law System}

1. The instrumentalist attitude toward wilderness.

Early Americans viewed the seemingly endless ${ }^{64}$ wilderness

ation of Texas, the 1846 Oregon Compromise, and the 1848 Treaty of Guadalupe Hidalgo-further increased the extent of this publicly owned wilderness. See 16th CEQ Report at 34 fig 2-2 (cited in note 2). When this expansionist period ended with the 1853 Gadsden Purchase, the territory of the United States included all of the land which now comprises the contiguous forty-eight states. Id.

${ }^{3 s}$ See id at 35. For a detailed discussion of federal land disposal policies during the nineteenth century, see Gates, Public Land Law at 121-494 (cited in note 40).

${ }_{59}$ See 16th CEQ Report at 35 (cited in note 2); see also Cox, et al, Well-Wooded Land at 56-60 (cited in note 14) (discussing colonial attitudes toward the American forests).

${ }^{60}$ See Gates, Public Land Law at 132-33 (cited in note 40).

61 See id at 219-84 (describing the epic struggle for squatters' preemptive purchase rights, the slow abandonment of the prohibition on squatting, and the complex military land bounty system).

6212 Stat 392, codified at 43 USC $\$ \S 161$ et seq (1891), repealed by Pub L No 94-579, 90 Stat 2787 (1976). For the text and legislative history of the Act, see Irving J. Sloan, 1 American Landmark Legislation 3-74 (Ọceana 1976).

${ }_{63}$ See 15th CEQ Report at 364 (cited in note 6) (noting that much of the remaining federal land was "relatively sparse as a pool of biological and genetic diversity," in part because "these were "the lands that nobody wanted").

64 In particular, the American forest appeared limitless:

The forest could hardly have seemed otherwise to an Englishman, whose home country was built to a very different scale, where a wooded expanse of one hundred acres was a major forest.... . How different was America, where the forest environment made possible a conviction ... that the forest was at once the source of subsistence and a wilderness whose conquest was the key to that future of plenty that early 
with repugnance. ${ }^{65}$ It impeded progress, retarded prosperity, and blocked national expansion. ${ }^{66}$ Pioneers attacked the wilderness relentlessly, destroying forests with girdling ${ }^{67}$ and fire. ${ }^{68}$ As the historian Roderick Nash observed, the "reduction of the amount of wilderness defined man's achievement as he advanced toward civilization. .69

Unsurprisingly, the judiciary shared this societal prejudice. Early nineteenth-century opinions characterizing wilderness typically reflect the ideology of exploitative utilitarianism: $:^{70}$ land in its natural condition was considered essentially worthless until converted to human use. ${ }^{71}$ Three decisions of the United States Supreme Court illustrate this perspective. In resolving a title dispute to a large Kentucky tract, for example, Justice Story lamented that the property consisted of "waste and vacant lands"

Americans sought for themselves and their descendants.

Cox, et al, Well-Wooded Land at 12 (cited in note 14).

${ }_{6}$ As a French traveler observed after an early nineteenth-century journey through the new United States: "There is [ ] in America a general feeling of hatred against trees. .. They believe that the absence of woods is the sign of civilization; nothing seems uglier than a forest; on the contrary, they are charmed by a field of wheat." Pierson, Tocqueville and Beaumont at 193 (cited in note 38). See also Nash, Wilderness and the American Mind at 23-43 (cited in note 34) (discussing the early American attitude toward wilderness); Cox, et al, Well-Wooded Land at 54 (cited in note 14) (observing that pioneer settlers shared "a widespread hostility to trees, an attitude that they should be eliminated as soon as possible").

${ }_{66}$ See Nash, Wilderness and the American Mind at 40 (cited in note 34) ("Insofar as the westward expansion of civilization was thought good, wilderness was bad. It was construed as much a barrier to progress, prosperity, and power as it was to godliness."). But the antiwilderness fervor was not universal. As early as the eighteenth century, the vast American wilderness helped inspire the Romantic movement among European intellectuals. Id at 44-66. Transplanted to the United States and nurtured by Henry David Thoreau's epic Walden, the seeds of this movement ultimately blossomed into a late-nineteenth-century effort to preserve the American wilderness. See id at 96-107.

${ }^{67}$ Girdling, a frontier method of killing trees, consisted of "cutting a ring around the [tree] trunk near its base so as to sever the life-sustaining layer that carries food to the roots." Cox, et al, Well-Wooded Land at 9 (cited in note 14). For a discussion of pioneer girdling practices, see id at 9-10, 12 fig 1. See also Pierson, Tocqueville and Beaumont at 241 (cited in note 38 ) (recounting Alexis de Tocqueville's observations of girdling practices).

6 For a discussion of the use of fire to clear forests in early America, see Cox, et al, Well-Wooded Land at 10, 13 fig 1 (cited in note 14).

${ }^{69}$ Nash, Wilderness and the American Mind at 9 (cited in note 34).

${ }^{70}$ For a discussion of exploitative utilitarianism in the property context, see Sprankling, 79 Cornell L Rev at 856-57 (cited in note 9).

"Many decisions, reflecting the prevailing mindset of the era that undeveloped regions were useless, characterized wilderness as "waste" lands. See, for example, Bradstreet $v$ Huntington, 30 US (5 Pet) 402, 448 (1831) (equating wild lands with "waste" lands); Pierson v Post, 3 Cai R 175, 175 (NY 1805) (referring to "certain wild and uninhabited, unpossessed and waste land"). 
in "a mere uncultivated country, in wild and unpenetrable woods, in the sullen and solitary haunts of beasts of prey ...."72 In another opinion, the Court compared an eight-thousand-acre Kentucky parcel to "pathless deserts." Finally, in deciding a third case, the Court characterized Virginia land as "an immense unexplored wilderness, covered with savages equally fierce and hostile."74 State courts mirrored the same antipathy. Chancellor Kent considered New York wilderness an obstacle to be "subdued,"75 while the Tennessee Supreme Court denigrated forests as "incumbrances" to cultivation. ${ }^{76}$

Under this utilitarian ideology, wilderness lands were destined to be exploited for human gain. In Johnson $v$ M'Intosh, for example, Chief Justice Marshall relied upon this proposition while rejecting the assertion that Native Americans possessed the right to convey their tribal lands. He defended the European conquest of America with the explanation that to "leave [Native Americans] in possession of their country, was to leave the country a wilderness," a consequence seemingly so abhorrent as to end debate. ${ }^{77}$ For Marshall and other judges of the era, the progressive conversion of "unbroken forests" into farm land fit for "agriculturalists" was both desirable and inevitable. ${ }^{78}$

This ideology spawned an American judicial attitude that strongly favored the agrarian development of wilderness land. ${ }^{79}$

${ }^{72}$ Green $v$ Liter, 12 US (8 Cranch) 229, 249 (1814).

${ }^{73}$ Davis $v$ Mason, 26 US (1 Pet) 503, 507 (1828).

${ }^{74}$ Massie $v$ Watts, 10 US (6 Cranch) 148, 164 (1810).

75 Goodell $v$ Jackson, 20 Johns 693, 711 (NY 1823).

${ }^{76}$ Townsend $v$ Shipp's Heirs, 3 Tenn (Cooke) 293, 300 (1813).

7721 US ( 8 Wheat) 543, 590 (1823). Justice Marshall's description of the pattern of European settlement was succinct: “As the white population advanced, that of the Indians necessarily receded. The country in the immediate neighbourhood of agriculturalists became unfit for them. The game fled into thicker and more unbroken forests, and the Indians followed. The soil ... being no longer occupied by its ancient inhabitants, was parcelled out ...." Id at 590-91.

${ }^{78}$ Id at 590-91. Thirteen years later, the Supreme Court similarly rejoiced that "property, which within a few years was but of little value, in a wilderness, is now the site of large and flourishing cities ...." Voorhees $v$ Bank of the United States, 35 US (10 Pet) 449,473 (1836).

79 Examples of this judicial mentality are legion. In Hart's Heirs $v$ Baylor, the Kentucky Supreme Court considered whether an occupant who had cleared part of a 350-acre wilderness tract for cultivation was entitled to compensation under the good faith improver doctrine. $3 \mathrm{Ky}$ (Hard) 597, 601 (1808). The court commented that:

To use the land for habitations, cultivation, and erection of such machineries, and manufactories, as are useful and necessary in society, is the proper end, and intent, for which ownership is given. Society is interested in the proper exercise of that ownership. Every class of citizens, depend, ultimately, upon the agriculturalist for sup- 
Certainly, the underlying English common law of property emphasized productive land use to some extent, ${ }^{80}$ however, in postwilderness England, this policy primarily encouraged the continued use of developed land, typically farm land. ${ }^{81}$ The new American orientation-designed to stimulate the creation of productive land through the destruction of wilderness-was fundamentally different.

\section{Land-use disputes between co-owners: waste.}

The American approach to the doctrine of waste presents the most obvious example of antiwilderness retooling. ${ }^{82}$ In England, waste was the principal common law mechanism for resolving land-use disputes between persons holding successive or concurrent interests in the same land. ${ }^{83}$ Absent a superseding agreement, waste governed the rights and duties of joint tenants, tenants in common, life tenants, tenants for years, and the like. ${ }^{84}$ Early-nineteenth-century American courts, however, rejected this

port .... Public policy, therefore, demands that agricultural pursuits and improvements, should be encouraged.

Id at 601.

The United States Supreme Court echoed this sentiment. In Smith v Turner, for example, Justice Grier's concurring opinion noted the nation's "many millions of acres of vacant lands" and lauded "the cherished policy of the general government to ... convert these waste lands into productive farms ... ." 48 US ( 7 How) 282, 461 (1849) (Grier opinion). Similarly, in Holland $v$ Challen, while adjudicating a title dispute to "unoccupied, wild, and uncultivated land," the Court observed that "[i]t is manifestly for the interest of the community that conflicting claims to property thus situated should be settled, so that it may be subjected to use and improvement. ${ }^{n} 110$ US 15, 21 (1884).

so See, for example, Dutton v Tayler, 125 Eng Rep 819 (CP 1701) ("It is pro bono publico that the land shall not be unoccupied."), cited in Dillman $v$ Hoffman, 38 Wis 559 , 574 (1875).

${ }^{81}$ See text accompanying notes $18-26$.

62 See John Henry Merryman's thoughtful analysis of the role of public policy in the early evolution of the American law of waste in A. James Casner, ed, 5 American Law of Property \$ 20.5 at 86-88 (Little, Brown 1952); see also Horwitz, Transformation of American Law at 54-58 (cited in note 12) (discussing waste generally).

$\$ 3$ The common law in both England and the United States imposed virtually no landuse limitations on the holder of fee simple absolute title, absent nuisance-like conduct. See text accompanying notes 184-97. As the Pennsylvania Supreme Court observed in 1886: "It must be conceded, we think, that every man is entitled to the ordinary and natural use and enjoyment of his property. He may cut down the forest trees, clear and

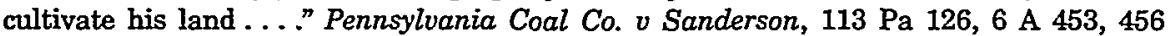
(1886).

See generally Powell, 5 Real Property If 639 at 56-11 (cited in note 23) (discussing the types of property interests subject to the waste doctrine). 
semipreservationist English doctrine as unsuited to wilderness conditions. ${ }^{85}$

In England, waste tended to perpetuate the land-use status quo; it resolved disputes between competing interest holders by preferring existing uses to new uses. Altering the character of land-for example, converting forest to farm land-was deemed waste. ${ }^{86}$ Similarly, subject to intricate exceptions for wood used on the property for fuel and repairs, any cutting of "timber" trees-such as oak, ash, and elm ${ }^{87}$-generally constituted waste. ${ }^{88}$ In part, these precepts reflected a wood-dependent economy $^{89}$ increasingly hobbled by a wood scarcity. ${ }^{90}$ Confronted with the choice between exploiting or conserving the nation's dwindling forests, English law unsurprisingly favored conservation.

Suppose that during this era English farmer $A$ holds a tenancy for years in a tract consisting of ten acres of farm land and five acres of forest, with a reversion in his landlord $B$. Aware of the high price he could obtain for firewood, ${ }^{91} A$ plans to log the forest, sell the wood, and raise crops on the newly cleared land. Suppose further that $B$ objects, on the basis that production of wood for fuel is maximized in the long term by periodic branch cutting, not logging. ${ }^{92}$ As between $A$ and $B$, the English waste doctrine would sustain $B$ 's objection, thereby facilitating $B$ 's conservation effort.

In the United States-a land endowed with apparently inexhaustible wilderness, but little farm land-the English doctrine would have arrested development. Driven by the instrumentalist

${ }_{85}$ See notes 93-104.

${ }^{86}$ See note 23. See also Pynchon v Stearns, 52 Mass (11 Met) 304, 310 (1846) (discussing English rule); Jackson v Brownson, 7 Johns 227, 229-37 (NY 1810) (same); Hastings $v$ Crunckleton, 3 Yeates 261, 261-62 (Pa 1801) (same).

87 See Casner, ed, 5 American Law of Property $\$ 20.2$ at 75 (cited in note 82).

8 A tenant for years, for example, was entitled to cut wood for fuel to be used on the premises ("estovers") and for reasonable repairs. See id $\S \S 20.4-20.5$ at 84, 86-87.

${ }^{89}$ For an analysis of England's wood dependency, see Perlin, Forest Journey at 21145 (cited in note 22). See also Cox, et al, Well-Wooded Land at 26-32 (cited in note 14) (discussing England's heightened dependency on colonial and foreign wood supplies).

${ }^{90}$ See notes 22-23.

91 "Between about 1540 and 1570 the price of firewood [in England] doubled, and by about 1630 it had doubled again, and then tripled. ... The crisis was felt by all social classes. For the common people, perhaps the worst effect was the severe shortage of fuel for heating." Cox, et al, Well-Wooded Land at 26 (cited in note 14).

${ }_{92}$ During the Middle Ages and long thereafter, English forests were operated much like crop lands in order to maximize wood production. See Rackham, Trees and Woodland at 58-83 (cited in note 18). Under this system, branches were periodically harvested from standing trees, using techniques such as coppicing and pollarding. Id at 8-10, 55-56. 
vision, nineteenth-century American courts resoundingly jettisoned the waste doctrine's ban on clearing forest land for cultivation. New York, North Carolina, and Pennsylvania spearheaded this movement, and, by 1810 , every state had expressly rejected the rule. ${ }^{93}$ The Supreme Court of Pennsylvania, for example, noting the "material difference between the local circumstances of this state and of Great Britain," reasoned that "[l]ands in general with us are enhanced by being cleared," and concluded that "[i]t would be an outrage on common sense" to apply the English doctrine. ${ }^{94}$ Instead, these early decisions adopted a "good husbandry" standard, under which clearing forest land for agriculture did not constitute waste provided that a small portion of the forest was retained to provide wood for fencing, firewood, and other farm needs. ${ }^{95}$

Over the ensuing decades, almost all of the states to consider the issue adopted the good husbandry standard, stressing the need to convert the American wilderness into agricultural land. ${ }^{96}$ The Supreme Court of Tennessee explained that "[i]n this country, where so large a proportion of the lands are wild, and yet in forest, it is often of great advantage to the estate to destroy the timber and reduce the land to a state of cultivation." 97 The Supreme Court of Indiana sounded the same instrumentalist theme: "The fact that a large portion of our territory consists of vast forests, requiring, in advance of improvements and the increase of population, that these forests should be turned into cultivated fields, makes the rule of the common law ... wholly inapplicable."

93 See, for example, Jackson, 7 Johns at 228, 233 (noting that lessee "undoubtedly had a right" to clear for agriculture part of parcel of "wild and uncultivated" land covered with "heavy timber"); Ballentine v Poyner, 3 NC (2 Hayw) 110, 111 (1800) (holding that widow exercising dower rights could clear "wood lands" for agriculture); Hastings, 3 Yeates at 262 (same).

94 Hastings, 3 Yeates at 262.

95 Jackson, 7 Johns at 233. See also Ballentine, 3 NC at 111; Hastings, 3 Yeates at 262.

96 See, for example, Proffitt $v$ Henderson, 29 Mo 325, 327 (1860) (noting, in case involving 150-acre forest tract, that the American rule on waste "is somewhat varied from English law, and is more enlarged and better accommodated to the circumstances of a new and growing country"); Crockett $v$ Crockett, 2 Ohio St 180, 184 (1853) (commenting, in case involving "wild lands," that "it is well settled that many things may be done by a tenant for life here, that if done in England would be waste; as, for example, the conversion of ... . woodland into a farm"). See also Pynchon, 52 Mass (11 Met) at 310 (Cultivating meadowland is not waste if it is a reasonable use of the land.).

97 Owen v Hyde, 14 Tenn (6 Yer) 334, 339 (1834).

98 Dawson v Coffman, 28 Ind 220, 223-24 (1867). 
Much American forest land, however, was not suitable for agriculture even when cleared; steep terrain, poor soil, and excess water all impeded cultivation. Did cutting timber on such land constitute waste? The nineteenth-century judicial answer to this question was muted. Some courts flatly authorized logging, reasoning that it was the only possible productive use of such parcels. ${ }^{99}$ Most courts, however, although acknowledging the obvious differences between the American and English landscapes, ${ }^{100}$ merely eroded the traditional rule; melding rationales based on economic necessity and presumed owner intent, these courts permitted logging if the previous owner had engaged in such activity. ${ }^{101}$ One illustrative decision involved a widow's dower claim to eight thousand acres of Virginia "swamp land" that was "incapable of cultivation"; ${ }^{102}$ the land had "no otherwise productive or valuable use other than by working the timber, and making sale thereof when converted into shingles," as her husband had done during his lifetime. ${ }^{103}$ Observing that the law of waste "must be varied and accommodated to our new and comparatively unsettled country," the Virginia Supreme Court upheld the widow's right to cut a reasonable amount of timber. ${ }^{104}$

99 See, for example, Ballentine, $3 \mathrm{NC}$ at 111 (noting that if timber cutting "respects juniper swamp, and other lands similarly circumstanced, where the timber made into staves and shingles, is the only use to be made of the lands, then the devisee or widow shall not be liable to waste for using such timber, according to the ordinary use made of the same in that part of the country"). Compare Bartlett v Pickering, 113 Me 96, 92 A 1008, 1009-10 (1915) (observing, in a case involving "wild, uncultivated land, covered with a forest growth of pine, fir, cedar, and hard woods," that since wild lands in Maine are generally valuable only for "income-producing purposes," it must have been contemplated that the cutting and sale of marketable trees would be allowed).

${ }^{100}$ See note 94 and accompanying text.

101 See, for example, Williard $v$ Williard, $56 \mathrm{~Pa} 119$, 128-29 (1867) (rejecting claim of waste against life tenant engaged in "cutting and rafting timber," where "the pine lands ... are often valuable only for their timber, and are bought solely for this use"). See also Carr v Carr, 20 NC (4 Dev \& Bat) 317, 318 (1838) (Dowress may work trees for turpentine if her husband worked them before her.); Macaulay's Executor $v$ Dismal Swamp Co., 41 Va (2 Rob) 507, 525, 529-30 (1843) (Dowress may cut and sell trees as her husband did.); Lee \& Bradshaw v Rogers, $151 \mathrm{Ga} 838,108 \mathrm{SE} 371,373-74$ (1921) (same).

${ }^{102}$ Macaulay's Executor, $41 \mathrm{Va}(2 \mathrm{Rob})$ at 527.

103 Id at 527.

104 Id at 528. The court analogized to the English "open mines" doctrine, under which the continued working of a preexisting mine was not considered waste: "It is, in truth, a mine upon the surface; not of minerals, incapable of renewal, but of vegetable matter, in a constant course of spontaneous reproduction." Id at 529. 
3. Title disputes between competing claimants.

Development of the nation's wilderness lands could be effected only by productive settlers. Yet ownership of land by nonresident speculators was widespread in the nineteenth century. ${ }^{105}$ Speculators typically left land undisturbed while waiting for its value to increase, thus impeding regional growth. ${ }^{106}$ The exploitation of wilderness land by actual settlers was generally preferred to the perceived neglect which characterized absentee ownership.

Nineteenth-century American courts manipulated English land title doctrines to exalt the user over the idler. ${ }^{107}$ The re-

105 As George Washington observed in 1784, "Such is the rage for speculating in, and forestalling of Lands on the No. West side of the Ohio, that scarce a valuable spot within any tolerable distance of it, is left without a claimant. Men in these times, talk with as much facility of fifty, a hundred, and even 500,000 Acres as a Gentleman formerly would do of 1000 acres." Letter from George Washington to Jacob Read (Nov 3, 1784), in John C. Fitzpatrick, ed, 27 The Writings of George Washington 485, 486 (US GPO 1938). During the ensuing decades, speculators purchased millions of wilderness acres. Gates, Public Land Law at 68-71 (cited in note 40). In one such mammoth transaction, for example, a private investment syndicate purchased eleven million acres of "unsettled and uncultivated" lands in the Mississippi Territory, an area almost as large as the states of Vermont and New Hampshire combined. See Brown $v$ Gilman, 17 US (4 Wheat) 255, 256, 297 (1819).

${ }^{106}$ Gates, Public Land Law at 149 (cited in note 40). Indeed, in some areas, residents tried to discourage absentee owners-and thus induce resale to actual settlers-by removing timber and pasturing cattle on such lands. Id at 150.

${ }^{107}$ The American wilderness similarly influenced the nineteenth-century evolution of the quiet title action. Multiple, overlapping land claims were common in the era. In Kentucky, for example, "Conflicts of title were unfortunately so numerous, that no one knew from whom to buy or take lands with safety ...." Clark $v$ Smith, 38 US (13 Pet) 195, 202 (1839). The traditional English mechanism for adjudicating competing title claims-ejectment-was useless to many disputants. As an element of an ejectment claim, the plaintiff was required to allege that he had actually possessed the land; because many claimants to wilderness land had never taken possession of it, they could not obtain judicial relief. This insecurity of land title hindered the development of wilderness land. As the Supreme Court observed in an 1884 opinion involving "unoccupied, wild, and uncultivated land":

Few persons would be willing to take possession of such land, enclose, cultivate and improve it, in the face of a disputed claim to its ownership.... An action for ejectment for it would not lie, as it has no occupant; and if, as contended by the defendant, no relief can be had in equity because the party claiming ownership is not in possession, the land must continue in its unimproved condition. It is manifestly for the interest of the community that conflicting claims to property thus situated should be settled, so that it may be subjected to use and improvement.

Holland $v$ Challen, 110 US 15, 21 (1884). In order to break the resulting stalemate, many nineteenth-century American courts developed an exception to the English rule by allowing a claimant to "wild lands" to sue in ejectment without alleging prior actual possession. See, for example, Harding $v$ Guice, 80 F 162, 162 (4th Cir 1897) ("wild and uncultivated" 
configured doctrines tended to transfer title to wilderness land to exploitative claimants. For example, suppose $C$, a productive settler, and $D$, an indolent speculator, both claimed title to the same wilderness tract. Under circumstances where English law would favor $D$, American courts increasingly vested title in $C$. As the Kentucky Supreme Court reasoned in 1808, "[t]o use the land for habitations [and] cultivation ... is the proper end ... for which ownership is given." ${ }^{108}$

a. Adverse possession. Adverse possession evolved in England as a method to protect the true owner of land by barring ancient (and presumably frivolous) claims, much like a modern statute of limitations. ${ }^{109}$ In a heavily populated, agricultural country lacking an effective title recording system, long-term possession was optimum evidence of ownership. ${ }^{110}$ Under these circumstances, it was reasonable to expect that the true owner of property would either reside there or, at least, inspect it frequently enough to detect trespassers and bring a timely suit in ejectment. On the other hand, lengthy possession uninterrupted by litigation could be construed as community acknowledgement that the occupant was the true owner. Under this approach, the key elements of adverse possession-actual possession, hostility, exclusivity, continuity, openness and notoriety-afforded constructive notice to the world of the occupant's title claim. ${ }^{111}$

The courts of the new United States initially followed the English model of adverse possession by requiring evidence that the adverse claimant had engaged in activities likely to afford notice to an inspecting owner: residence, cultivation, fencing or other improvement. ${ }^{112}$

lands); Sanders v Devereux, 60 F 311, 313 (8th Cir 1894) ("wild" land); Mitchell v Etter, 22 Ark 178, 180 (1860) ("wild" land); Sloan v Sloan, 25 Fla 53, 5 S 603, 606 (1889) ("wild and unoccupied" lands); Spithill v Jones, 3 Wash 290, 28 P 531, 531 (1891) ("unoccupied" land); Taylor v Rountree, 28 Wis 391, 397 (1871) ("wild, uncultivated" prairie land).

${ }^{103}$ Hart's Heirs v Baylor, 3 Ky (Hard) 597, 601 (1808).

${ }^{109}$ I analyzed the evolution of nineteenth-century American adverse possession doctrine in detail in Sprankling, 79 Cornell L Rev at 841-49 (cited in note 9). Accordingly, I include only a brief discussion here to illustrate the overall judicial approach to wilderness land.

${ }^{10}$ See A. James Casner, ed, 4 American Law of Property $\S 17.5$ at 536-37 (Little, Brown 1952) (describing the English land record system); Best, Land Use at 14-16 (cited in note 18) (describing eighteenth-century land use in England).

111 See Sprankling, 79 Cornell L Rev at 816-23 (cited in note 9).

112 See, for example, Proprietors of the Kennebeck Purchase v Springer, 4 Mass 416, 418-19 (1808) (holding that the acts of cutting grass and marking boundaries were insufficient because they would not afford notice to owner); Grant $v$ Winborne, 3 NC (2 Hayw) 
Nineteenth-century American courts, however, transformed the doctrine in order to promote the development of wilderness land. ${ }^{113}$ They slowly abandoned the requirement of residence, cultivation, or improvement in cases involving such lands; instead, they adopted a new yardstick, which measured the acts required for adverse possession by the nature and character of the land involved. ${ }^{114}$ The paradigm adverse possession suit of the era was a contest between $E$, an absentee owner holding title, and $F$, a settler or other adverse claimant who had put the land to productive use. By lowering the legal threshold for adverse possession of wilderness land, courts tended to transfer title from idle owner $E$ to proven user $F$, whose development track record predicted future exploitation.

The new "wild lands" standard had no logical link with constructive notice. Under this calculus, adverse possession of wilderness land could be premised on infrequent, inconspicuous actions that were unlikely to afford notice to anyone. Thus, for example, berry picking and occasional timber cutting, ${ }^{115}$ seasonal sheep grazing, ${ }^{116}$ and the sporadic use of forest as woodlot $^{117}$ all sufficed to vest title in nineteenth-century claimants. Accordingly, it became much easier to adversely possess wilderness than developed land. As a twentieth-century jurist later explained, adverse possession law evolved "when much of the continental United States was unsurveyed wilderness" such that

56,57 (1798) (noting that acts such as feeding cattle or cutting wood might be done "so secretly as that the neighborhood may not take notice of it," although notice of an adverse claim would be provided if "a settlement is made upon the land, houses erected, lands cleared and cultivated").

${ }^{113}$ Seddon v Harpster, 403 S2d 409, 413 (Fla 1981) (Boyd concurring in part and dissenting in part) (explaining that based on a public policy that as much of the "unsurveyed wilderness ... should be put to use as possible," courts in the nineteenth century "imbued a presumption of ownership on the persons who actually possessed the property").

${ }^{14}$ See, for example, Bell $v$ Denson, 56 Ala 444, 449 (1876) (noting that "possession must be by acts suitable to the character of the land"); Mooney $v$ Cooledge, 30 Ark 640, 655 (1875) (observing that "much depends upon the nature of the situation of the property and the use to which it can be applied"); Worthley $v$ Burbanks, 146 Ind 543, $45 \mathrm{NE} 779$, 781 (1897) (concluding that "much depends on the nature and situation of the property, the uses to which it can be applied"). See also Sprankling, 79 Cornell L Rev at 848-49 (cited in note 9) (analyzing the shift toward measuring the sufficiency of adverse possession acts based on the nature and character of the land involved).

${ }^{115}$ Worthley, $45 \mathrm{NE}$ at 780 (involving claim of adverse possession of "barren sand ridges" and "sloughs").

${ }_{116}$ Webber v Clarke, $74 \mathrm{Cal} 11,15 \mathrm{P} 431,435$ (1887) (involving adverse possession claim to unenclosed rangeland).

${ }^{117}$ Murray v Hudson, 65 Mich 670, 32 NW 889, 891 (1887) (involving adverse possession claim based on use of forest as woodland "in the usual and ordinary way"). 
"the courts adopted a public policy that as much land should be put to use as possible."118

b. Possession and the bona fide purchaser. The lineage of the American title recording system may be traced to the $\mathbf{1 5 3 6}$ Statute of Enrollments, which required the registration of English deeds. ${ }^{119}$ Mere delivery of a deed to the grantee was insuffcient to transfer title; a conveyance became effective only upon registry in the "king's courts of record at Westminster."120 Although the statute and its successors were eventually circumvented by various legal devices, ${ }^{121}$ this farsighted effort ultimately served as a model for the highly successful American system.

One early English exception to the universal enrollment rule, however, was the bona fide purchaser doctrine. Equity courts construed the seemingly absolute language of the registry statutes as protecting only the grantee without actual notice of previously created interests. ${ }^{122}$ In thickly settled England, however, the prior grantee who resided on, cultivated, or visibly improved his land provided effective notice of his entitlement to subsequent claimants; such possession was the judicial equivalent of actual notice. Later courts eventually restricted the doctrine in this context by holding that if a prior grantee under a nonregistered deed held possession of his land, then a subsequent grantee of the same property was charged with constructive notice of the prior grantee's claim and was therefore not shielded by the enrollment system. ${ }^{123}$

118 Seddon, 403 S2d at 413 (Boyd concurring in part and dissenting in part).

11927 Hen 8, ch 16 (1536). See also Casner, ed, 4 American Law of Property $\S 17.5$ at 537-38 (cited in note 110) (discussing the Statute of Enrollments and its impact on the American recording system). The Statute of Enrollments provided:

[N]o manors, lands, tenements or other hereditaments shall pass, alter or change from one to another ... by reason only of any bargain and sale thereof, except the same bargain and sale be made by writing indented, sealed and enrolled in one of the king's courts of record at Westminster ... within six months next after the date of the same writing indented.

J.H. Baker and S.F.C. Milsom, Sources of English Legal History: Private Law to 1750115 (Butterworth 1986).

120 Baker and Milsom, Sources of English Legal History at 115 (cited in note 119).

121 Casner, ed, 4 American Law of Property $\$ 17.5$ at 536-41 (cited in note 110) (discussing the limited significance of the Statute of Enrollments and its successors).

122 Id $\S 17.5$ at 539 .

${ }^{123}$ See, for example, Lessee of Billington $v$ Welsh, 5 Binn 129, 133-35 (Pa 1812) (discussing English cases). 
Even as American legislatures emulated the English pattern in crafting a statutory recording system, ${ }^{124}$ most early American courts paralleled the equity court approach by construing these statutes to protect only bona fide purchasers. ${ }^{125}$ These courts also accepted the English parameters of the exception: a later grantee was denied protection only where he was charged with knowledge of a prior grantee's interest, either through actual notice or through constructive notice stemming from the grantee's possession of the property. ${ }^{126}$ As the Pennsylvania Supreme Court reasoned in 1812, "[t]he undisturbed possession of land[ ] has generally been considered as legal notice, because the fact of possession being notorious, it is sufficient to put the purchaser on his guard ...."127 But the key assumption underlying the English approach-that a prospective buyer would carefully inspect land before purchasing it ${ }^{128}$-often failed under American wilderness conditions. Buyers of remote, inaccessible wilderness tracts frequently did not inspect them in advance, ${ }^{129}$ and thus were charged with constructive notice of the claims of resident settlers. Transplanted to America, then, the bona fide purchaser doctrine tended to protect the titles of wilderness settlers at the expense of absentee speculators, thereby facilitating agricultural development.

Nonetheless, the English insistence that possession measured by occupancy formed the keystone of constructive notice proved troublesome. Under wilderness conditions, settlers holding unrecorded deeds often used one parcel for woodlot, pasture, or hunting, while residing on another tract. ${ }^{130}$ Following the

${ }^{124}$ See George L. Haskins, The Beginnings of the Recording System in Massachusetts, 21 BU L Rev 281, 291-93 (1941).

${ }_{125}$ See, for example, Pritchard v Brown, $4 \mathrm{NH} 397,404-05$ (1828) (following English approach); Billington, 5 Binn at 133-35 (same); Lessee of Cherry $v$ Robinson, 1 Yeates 521, 523 ( $\mathrm{Pa}$ 1795) (same). Echoing the English standard, the court in Colby $v$ Kenniston concluded: "He, who takes a conveyance of land, knowing that another person has a previous conveyance of the same land from the same person by an unrecorded deed, is guilty of a fraud and cannot hold the land." $4 \mathrm{NH} 262,266$ (1827).

126 See, for example, Prescott $v$ Heard, 10 Mass 60, 63 (1813) (holding buyer should have been on notice that seller did not have title to land in light of lengthy residence by third party); Davis $v$ Blunt, 6 Mass 487 (1810) (stating defendant, seeing plaintiff "in the daily occupation" of the land, had notice of plaintiff's title).

${ }_{122}$ Billington, 5 Binn at 132.

${ }_{128}$ See Sprankling, 79 Cornell L Rev at 822 (cited in note 9) (noting that lack of dense forests in England eased task of inspecting land).

129 See Gates, Public Land Law at 69 (cited in note 40) (noting that "[i]n periods of great speculation land was frequently bought" on a "sight unseen" basis).

130 See, for example, Knox $v$ Thompson, $11 \mathrm{Ky}$ (1 Litt) 350, 352-53 (1822) (involving owner of fifty partially cultivated acres); M'Mechan $v$ Griffing, 20 Mass (3 Pick) 149, 150- 
English formula, early American courts held that these transitory activities were legally insufficient to constitute possession. This limitation allowed later absentee buyers-often speculators-to wrest title from prior settlers. ${ }^{131}$

Faced with the paradigm conflict between the earlier settler and the later speculator, instrumentalist courts gradually reformulated the bona fide purchaser doctrine to promote wilderness exploitation. The battleground was the legal definition of "possession." Since possession of land had historically constituted constructive notice, an expansive redefinition of possession would correspondingly enlarge the range of cases in which courts could find such notice. Unsurprisingly, American courts slowly began to acknowledge that sporadic, exploitative activities on wilderness land constituted possession, and thus theoretically imparted constructive notice of a prior unrecorded deed, even absent the traditional benchmarks of residence, cultivation, or improvement. ${ }^{132}$

Under this regime, possession came to be measured by whether the first grantee had engaged in productive activity suited to wilderness land, regardless of whether this activity realistically imparted notice to later buyers. Thus, in a case involving forty acres of Iowa timberland, a prior settler holding an unrecorded deed who had "made such use of it as it was susceptible of in its then condition" by occasionally cutting timber prevailed over a later buyer. ${ }^{133}$ Other courts followed the same standard, generally requiring economic activities "adapted" to the nature and character of the land.

51 (1825) (involving owner who used woodland for pasture and timber, but resided elsewhere).

${ }_{131}$ See, for example, MMechan, 20 Mass (3 Pick) at 150-51 (holding that acts of tenant, including pasturing sheep and cattle, cutting trees and firewood, and mending fence, were insufficient to provide notice); Holmes v Stout, $10 \mathrm{NJ}$ Eq 419, 428-29 (1855) (holding that owner's cutting on twenty-two acres of "unenclosed woodland" was insufficient to provide notice).

${ }_{132}$ See, for example, Banner $v$ Ward, 21 F 820, 821-22 (C C D Minn 1884) (holding that cutting natural hay and seasonal sheep grazing were sufficient to provide constructive notice); Hubbard $v$ Long, 20 Iowa 149, 151 (1866) (concluding that periodic cutting in fifty acres of "timbered land" gave constructive notice). See also Mason v Mullahey, $145 \mathrm{Ill}$ $383,34 \mathrm{NE} 36,37$ (1893) (holding that cutting timber from woodland constituted notice); Nolan $v$ Grant, 51 Iowa 519, 1 NW 709, 710-11 (1879) (stating that plaintiff's cutting timber on lot constituted possession, thereby providing notice); Krider $v$ Lafferty, 1 Whart 303,318 ( $\mathrm{Pa} 1836$ ) (concluding that planting of willows on land was sufficient to constitute notice).

${ }^{133}$ Spitler $v$ Scofield, 43 Iowa 571, 572 (1876). 
This reformulation of the traditional doctrine is illustrated by a cluster of decisions holding that periodic tree cutting in forest areas constituted sufficient "possession" to impart constructive notice to subsequent grantees. ${ }^{134}$ For example, one court held that by annually cutting willows to use in basket making, a landowner protected his title to an eighteen-acre Pennsylvania parcel against a later claimant. ${ }^{135}$

A parallel group of decisions established that the use of unenclosed, natural grassland for seasonal pasturing constituted possession sufficient to preclude the claims of later purchasers. ${ }^{136}$ A United States Supreme Court decision involving 200 acres of West Virginia "wild lands, in an original state of nature," for example, explained that the acts that constituted possession (and thus afforded notice) must depend "to some extent on the nature, locality and use to which the property may be applied."137 Concluding that seasonal cattle grazing was "such possession as the land was susceptible of," the Court held that later buyers "had such notice as put them on inquiry and charged them with knowledge of the facts." ${ }^{138}$ In another decision exemplifying this redefinition, the owner of 320 prairie acres in a "sparsely settled" Minnesota region leased the land to tenants for seasonal sheep grazing and natural hay cutting.; ${ }^{139}$ these activities constituted "possession sufficiently notorious and exclusive, [to provide notice to a later claimant] when the condition and character of the land [was] taken into consideration." ${ }^{140}$

Such ephemeral activities were unlikely to afford notice even to the prospective buyer who actually inspected wilderness land.

134 See, for example, Nolan, $1 \mathrm{NW}$ at 710-11 (Cutting on 20 acres of timberland was sufficient as to entire tract, including 140 acres of prairie.); Hubbard, 20 Iowa at 151 (Cutting on 50 acres of land established possession.); Krider, 1 Whart at 318 (Planting and cutting of willows on 1-acre parcel held sufficient.); Stewart $v$ McSweeney, 14 Wis 468, 471 (1861) (Periodic "chopping" in forest area held sufficient.). Compare Kendall v Lawrence, 39 Mass (22 Pick) 540, 544 (1839) (Cutting of timber on 10 acres of woodland was evidence of constructive notice, albeit "very slight."). But see Holmes, $10 \mathrm{NJ} \mathrm{Eq}$ at 428-29 (Cutting on 22 acres of "unenclosed woodland" held insufficient to provide notice.).

135 Krider, 1 Whart at 318.

${ }_{135}$ See, for example, Simmons Creek Coal Co. v Doran, 142 US 417, 443 (1892) (Grazing cattle on 200 unfenced acres held sufficient.); Banner, $21 \mathrm{~F}$ at 821-22 (Grazing sheep and cutting seasonal hay held sufficient.). But see Coleman $v$ Barklew, 27 NJ L 357, 361 (1859) (Grazing cattle occasionally on 2.5-acre lot held insufficient.).

137 Simmons Creek Coal Co., 142 US at $424,443$.

139 Id at 443.

139 Banner, $21 \mathrm{~F}$ at 821.

140 Id. See also Buck v Holt, 74 Iowa 294, $37 \mathrm{NW} \mathrm{377,380} \mathrm{(1888)} \mathrm{(holding} \mathrm{plowing} \mathrm{of}$ furrow around 160 acres of prairie sufficient, even though later buyer inspecting land claimed he had not seen it). 
Suppose $G$ conveyed a two-thousand-acre forest tract to $H$, who failed to record his deed but occasionally removed timber from the land for use on his nearby farm. If unscrupulous $G$ again offered the land for sale, and prospective buyer $J$ inspected it, the size and topography of the parcel might prevent $J$ from noticing $H$ 's limited cutting. ${ }^{141}$ Even the actual observation of a few stumps would hardly signal the existence of a competing claim of title. In fact, it would be entirely reasonable for $J$ to assume that any such cutting was either authorized by $G$, the putative owner, or the result of an unauthorized trespass.

In this manner, American courts transformed constructive notice based on possession from a meaningful construct into a legal fiction. Much as the definition of "possession" evolved in the adverse possession setting, judges increasingly held in the bona fide purchaser context that owners of wilderness lands had "possession"-thus insulating their title from later claimants-based on sporadic, unnoticeable activities. By favoring the settler with a demonstrated intent to exploit his land over the untested later claimant, the reformulated doctrine allowed, and even encouraged, wilderness development to continue.

c. Good faith improver. Eighteenth-century English law afforded little protection to the mistaken improver of land. ${ }^{142}$ At common law, a person who improved another's property without his consent was a trespasser subject to punishment, not entitled to reward. ${ }^{143}$ Equity courts did, however, recognize one notable exception to this principle: in an ejectment action, the court could require that the successful owner compensate the losing occupant for the reasonable value of any improvements he had made in good faith. ${ }^{144}$ If the improver voluntarily surrendered possession

${ }^{141}$ Compare Klingel $v$ Kehrer, 81 Ill App 3d 431, 401 NE2d 560, 563-64 (1980) (One title claimant asserted he had occasionally cut trees on the disputed woodland parcel; the other claimant testified he had never seen any visible evidence of such cutting.).

142 The English approach to the problem of the mistaken improver of real property is well analyzed in John Henry Merryman, Improving the Lot of the Trespassing Improver, 11 Stan L Rev 456, 460-64 (1959). See also Kelvin H. Dickinson, Mistaken Improvers of Real Estate, 64 NC L Rev 37, 39-40 (1985) (briefly discussing English law).

${ }^{143}$ See Green $v$ Biddle, 21 US (8 Wheat) 1, 74-80 (1823) (discussing English law); Townsend $v$ Shipp's Heirs, 3 Tenn (Cooke) 293, 298 (1813) (stating that trespassers who improved owner's land without consent were not entitled to compensation).

${ }_{144}$ See, for example, Green, 21 US at 81-82; Townsend, 3 Tenn at 298-99. Another exception to this rule, less important in the context of this Article, was that in an action by an owner to recover profits from an occupant wrongfully in possession of land, the losing occupant could set off the reasonable value of his improvements against the profits sought. See Green, 21 US at 82, discussing dictum in Coulter's Case, 77 Eng Rep 98 (KB 
to the true owner, or failed to demand payment in the ejectment proceeding, however, he had no recourse. The law did not countenance an independent lawsuit against the owner for compensation. ${ }^{145}$

The meager scope of the good faith improver doctrine suited the developed English landscape. Because virtually the entire land surface was in productive agricultural use ${ }^{146}$ and the forest remnants were prized as woodlot, mistaken improver disputes typically involved an occupant who built a structure in a town or other populated area. In this setting, the erroneous erection of a building was viewed as interfering with the true owner's autonomy; it deprived the owner of his unfettered right to use his already-productive property as he saw fit.

But in the American wilderness, the semipreservationist orientation of the good faith improver doctrine made no sense. The eastern United States was almost completely covered by forest, while farm land was scarce. Accordingly, most early mistaken improver decisions involved occupants who cleared forest land for agricultural use. ${ }^{147}$ Such clearing normally enhanced land value and was thus deemed an improvement, even under the English standard. For example, when the innocent improver of "a wild and perfect wilderness" tract sought compensation for clearing part of the property, the Kentucky Supreme Court praised his effort in "subduing the forest, fitting the land for cultivation." ${ }^{148}$ The courts were unconcerned that the innocent improver might violate the true owner's autonomy, because any economically rational wilderness owner would welcome land clearing activity.

1599). See also Dickinson, 64 NC L Rev at 39-40 (cited in note 142) (discussing English exceptions to general rule of nonrecovery).

145 See Green, 21 US at 82-84; Dickinson, 64 NC L Rev at 40 (cited in note 142).

145 See note 20 (discussing the extent to which the land surface of England was in economic use).

${ }_{147}$ See, for example, Bell's Heirs v Barnet, $25 \mathrm{Ky}$ (2 JJ Marsh) 516, 518-20 (1829) (involving partial clearing of 300 acres of land); Ewing's Heirs $v$ Handley's Executors, 14 $\mathrm{Ky}$ (4 Litt) 346, 373-74 (1823) (involving partial clearing and cultivation of 250 acres of land); Lessee of G.N. Hunt $v$ McMahan, 5 Ohio 132, 132 (1831) (involving improver seeking compensation for 70 acres of "cleared land"); Administrators of Winthrop v Huntington, 3 Ohio 327, 327 (1828) (involving occupant who "improved the lands, by reducing them to cultivation"); Nelson v Allen, 9 Tenn (1 Yer) 360, 362 (1830) (involving occupant of 640 acres seeking compensation for the "quantity of land, cleared each year"); Pearce $v$ Frantum, $16 \mathrm{La} \mathrm{414,421-22} \mathrm{(1840)} \mathrm{(noting} \mathrm{that} \mathrm{felling} \mathrm{trees} \mathrm{and} \mathrm{fitting} \mathrm{land} \mathrm{for} \mathrm{agricul-}$ ture were compensable improvements).

${ }^{143}$ Ewing's Heirs, $14 \mathrm{Ky}$ at $369,373$. 
The limitations of the English doctrine tended to discourage settlement. ${ }^{149}$ Wilderness land titles were notoriously unreliable $;^{150}$ each prospective settler faced the risk that she might someday encounter an owner with superior title. If the true owner took possession without judicial action (for example, through entry during the occupant's temporary absence), the settler would lose the time and capital she had invested in improving the land. Confronted with such uncertainty, a prudent settler might tend to minimize her efforts. Although conceding in 1827 that enhanced protection for the good faith improver in a nation of "cultivated country" would be "unnecessary and pernicious," Chancellor Kent observed that the "peculiar and pressing circumstances" of "wild and unsettled lands in a new country" supported a more protective rule in the United States. ${ }^{151}$

Accordingly, the American property law system substantially reformulated English law to strengthen protection for the good faith improver. Nineteenth-century courts spearheaded this reform by establishing the right of a good faith improver to maintain an independent action for compensation. ${ }^{152}$ Confronted with such an action by an ousted settler in 1818, for example, the Kentucky Supreme Court noted the "absence of all precedent" permitting affirmative relief, but observed that the good faith possessor should recover under "principles of natural justice."153 Similarly, the Tennessee Supreme Court allowed the disap-

149 See Merryman, 11 Stan L Rev at 466 (cited in note 142) (noting that the application of English law in this context "tended to frustrate a then widely held view of public policy [that] it was important that wild land be settled and improved and that the law encourage this kind of activity").

${ }_{150}$ See, for example, Horwitz, Transformation of American Law at 61 (cited in note 12) (observing that in Kentucky as of 1823 , there were land claims equal to three times the acreage of the entire state); Gates, Public Land Law at 258-68 (cited in note 40) (discussing title confusion created by the use of land bounties as a reward for military service).

${ }_{151}$ James Kent, 2 Commentaries on American Law 274 (Halsted 1827). See also Horwitz, Transformation of American Law at 61-62 (cited in note 12) (mentioning the prodevelopment policy underlying betterment statutes); Dickinson, $64 \mathrm{NC} \mathrm{L} \mathrm{Rev} \mathrm{at} 46$ (cited in note 142) (noting that "the policy of encouraging development of the vast, uncultivated western lands" was a factor favoring expansion of the good faith improver doctrine).

${ }^{152}$ See, for example, Union Hall Association v Morrison, $39 \mathrm{Md} 281,282,293$ (1873) (allowing a bona fide improver of portion of one-hundred-acre tract known as "The Trap" to sue directly, despite "an absence of precedent in the English cases"); Hatcher $v$ Briggs, 6 Or 31, 40-41, 50 (1876) (allowing good faith improver on tract of timbered land to sue directly). See also Bright v Boyd, 4 F Cas 127, 132-33 (C C D Me 1841) (No 1,875) (recognizing rule); McKelway $v$ Armour, $10 \mathrm{NJ} \mathrm{Eq} \mathrm{115,} 118$ (1854) (recognizing rule). But see Putnam v Ritchie, 6 Paige Ch 390, 405 (NY Ch 1837) (refusing to recognize rule).

${ }^{153}$ Barlow v Bell, $8 \mathrm{Ky}$ (1 AK Marsh) 246, 246 (1818). See also Thomas v Thomas' Executor, 55 Ky (16 B Mon) 420, 424-25 (1855) (recognizing rule). 
pointed buyer under a defective purchase agreement to recover the value of his clearing work and other improvements. ${ }^{154} \mathrm{Al}-$ though other courts joined in this effort, the judicial movement was ultimately eclipsed by legislation. ${ }^{155}$ Many states enacted "betterment statutes" that expressly rejected the English doctrine and enlarged the protection afforded the good faith improver. ${ }^{156}$ As the California Supreme Court later explained, these statutes reflected a policy "to encourage settlement in good faith upon vacant lands as a means of developing agricultural interests."157

In sum, the good faith settler whose ownership claims proved unsuccessful-notwithstanding the antiwilderness reconfiguration of title doctrines such as adverse possession and bona fide purchaser-had a safety net: he could still recover compensation from the true owner for, in effect, destroying the natural condition of the land.

154 Herring \& Bird v Pollard's Executors, 23 Tenn (4 Hum) 362, 363 (1843) (noting that the disappointed buyer both "made valuable improvements" and "sold a quantity of [ ] timber" from the disputed property, described merely as a "tract of land"). Later Tennessee decisions recognized this principle as well. See, for example, Mathews $v$ Davis, 25 Tenn (6 Hum) 324, 327 (1845) (recognizing rule in context of verbal sales agreement concerning 100 acres upon which buyer erected farm buildings and related facilities); Rainer $v$ Huddleston, 51 Tenn (4 Heisk) 223, 226-27 (1871) (recognizing rule in case concerning occupant who cleared part of 297 -acre tract).

${ }_{155}$ According to the Reporters' Notes to the Restatement of Restitution (1937), this judicial reform effort would have spread to other states but for its interruption by the enactment of betterment statutes. See Warren A. Seavey and Austin W. Scott, Notes on Certain Important Sections of Restatement of Restitution 29 (ALI 1937) ("It seems likely that Story's view, which would permit restitution (see Bright $v$ Boyd, [4 F Cases 127, 13233 (C C D Me 1841) (No 1,875)]), would have prevailed, but for the prevalence of the socalled betterment statutes.").

156 The wave of nineteenth-century betterment statutes is discussed in Dickinson, 64 NC L Rev at $42-45$ (cited in note 142). The early betterment statutes were quite controversial. In Green, for example, the United States Supreme Court held a Kentucky betterment statute unconstitutional, despite a passionate plea from Henry Clay that a state with "waste and wilderness" territory had the inherent right to enact laws suitable to "reclaim it; to encourage its population; to promote cultivation." 21 US at 43. Dissenting, Justice Johnson complained that the English common law, characterized by "a thousand minute discriminations," was "appropriate to a state of society, and a state of property, having no analogy whatever to the actual state of things in Kentucky." Id at 104 (Johnson dissenting).

157 Billings $v$ Hall, 7 Cal 1, 15-16 (1857). See also McCoy v Grandy, 3 Ohio St 463, 468 (1854) (explaining the Ohio betterment statute as intended to encourage the "settlement of a wide extent of uncultivated land"); Townsend, 3 Tenn (Cooke) at 300 (observing, in connection with an early betterment statute, that "[i]n a waste and woodland country, as this is, the Legislature must have designed to favor those who had opened land, and had contributed to clear the country of the incumbrances of forest timber"). 


\section{Land-use disputes between neighboring owners.}

During the early nineteenth century, the combination of sparse population and seemingly infinite wilderness rendered land-use disputes between neighbors rare. But as wilderness development and population density accelerated, an increasingly large number of such disputes demanded legal resolution. Once again, the typical case pitted the user against the idler. For example, suppose $K$ maintained her four thousand acres of grassland in virtual wilderness condition, while her neighbor $L$ used his own one thousand acres of quasi-developed property for pasturing cattle. If $L$ 's cattle strayed onto $K$ 's land and devastated its vegetation, could $K$ successfully sue?

The English doctrines applicable to feuding neighbors-notably trespass and nuisance-focused on the protection of formalistic property rights inside boundary lines, with little concern for the distinction between use and disuse. English law thus tended to favor the idler over the user. Nineteenth-century American courts, however, softened these doctrines, and began to favor the user over the idler. Under the reformulated trespass doctrine, for example, $K$ 's historic right to be shielded from $L$ 's cattle was subordinated to the national interest in facilitating $L$ 's use of the land for grazing. Other neighboring-owner doctrines, including nuisance, easement by necessity, ${ }^{158}$ and the natural

$15 s$ Eighteenth-century English law uniformly demanded "strict necessity"-the lack of any legal right of access to a public road-as an element of an easement by necessity claim. See, for example, Collins v Prentice, 15 Conn 39, 43-44 (1842) (describing the English requirement of strict necessity); Pernam $v$ Wead, 2 Mass 203, 205 (1806) (same). Early nineteenth-century American decisions generally followed this strict necessity standard. Collins, 15 Conn at 43-44; Pernam, 2 Mass at 205. The logical consequence of this rule was that topography and other physical impediments to public-road access were irrelevant. Unsurprisingly, the history of the easement by necessity doctrine during the nineteenth century largely consists of slow movement toward a new "reasonable necessity" standard, under which wilderness impediments to public-road access-mountains, rivers, swamps, forests, and the like--justify granting one person an easement over the land of another.

By the end of the nineteenth century, courts in a number of states had adopted the reasonable necessity standard in the context of wild, undeveloped land. See, for example, Myers $v$ Dunn, 49 Conn 71, 74 (1881) (recognizing easement where necessity was caused by location of property on "high mountain ridge" which consisted of "woodland and pasture," because it was "not practicable on account of the steepness and rocky character of the land" to obtain access to the adjacent public road); Sanxay $v$ Hunger, 42 Ind 44, 45 (1873) (acknowledging easement due to necessity caused by "precipitous bluffs"); Schmidt $v$ Quinn, 136 Mass 575, 577 (1884) (recognizing easement by necessity to woodlot, using "practicable" standard); Mayo $v$ Thigpen, 107 NC 63, 11 SE 1052, 1052-53 (1890) (finding easement to woodland where necessity was caused by swampy conditions on legal access route); Alley $v$ Carleton, 29 Tex 74, 76, 79 (1867) (recognizing easement by necessity 
flow rule for excess surface water, ${ }^{159}$ reflect a similar reorientation.

a. Trespass. Eighteenth-century English trespass law cherished the owner's virtually absolute right to exclude others from his land. As Blackstone expressed it, "[e]very unwarrantable entry on another's soil" was considered a trespass because "every man's land is, in the eye of the law, inclosed and set apart from his neighbors ... either by a visible and material fense ... or by an ideal invisible boundary." familiar trespass problem. Because crop land and permanent pasture dominated the English landscape, the common law understandably held the stock owner liable for any damage his animals caused to a neighbor's land. For example, an owner was liable if his cattle trampled "down his neighbor's herbage" or "spoil[ed] his corn or his trees." The injured landowner was even allowed to engage in self-help by distraining the meandering stock until their owner paid appropriate damages. ${ }^{162}$ In ef-

despite river access).

159 The development of the "common enemy" doctrine for unwanted surface water-under which an owner could repel such water onto the land of another without liability-also reflects this antiwilderness bias to some extent. Eighteenth-century England followed the "natural flow" rule for excess surface water. See generally Richard A. Powell, 5A Powell on Real Property $\S 65.12[2][\mathrm{b}] \mathrm{n} 21$ at 65-202 (Matthew Bender 1995). Under this rule, an uphill landowner had the right to discharge excess surface water onto the property of his downhill neighbor, according to the natural contours of the land. Strict application of this rule tended to prevent either owner from changing the natural topography, and thus to frustrate land development. See A. James Casner, ed, 6A American Law of Property $\$ 28.63$ at 191 (Little, Brown 1954). Although American courts generally followed the English rule during the first half of the nineteenth century, over the next fifty years a number of jurisdictions rejected it in favor of the prodevelopment "common enemy" doctrine, often in the context of facilitating agricultural use of wild land. See, for example, Taylor $v$ Fickas, 64 Ind 167, 175-76 (1878) (holding that defendant had right under common enemy rule to discharge water onto plaintiff's lakefront land); Dickinson $v$ City of Worcester, 89 Mass (7 Allen) 19, 22 (1863) (holding that defendant had right under common enemy rule to repel water onto plaintiff's meadowland); Goodale $v$ Tuttle, $29 \mathrm{NY}$ 459, 466-67 (1864) (holding that defendant had right to discharge water onto plaintiff's marshland); Lessard $v$ Stram, 62 Wis 112, 22 NW 284, 285-86 (1885) (holding, in a region characterized by "lowlands" and "bluffs," that defendant had a right to turn flood waters onto plaintiff's land under the common enemy standard).

${ }_{160}$ Ehrlich, ed, Ehrlich's Blackstone at 576 (cited in note 13).

161 Id at 577. "A man is answerable for not only his own trespass, but that of his cattle also; for, if by his negligent keeping they stray upon the land of another (and much more if he permits or drives them on) and they there tread down his neighbor's herbage and spoil his corn or his trees, this is a trespass for which the owner must answer in damages." Id. For decisions reflecting the early American view of this English rule, see Rust $v$ Low, 6 Mass 90, 94 (1809); Coxe $v$ Rabbins, 9 NJ L 384, 385 (1828).

162 Ehrlich, ed, Ehrlich's Blackstone at 577 (cited in note 13). 
fect, a landowner's property was surrounded de jure by an invisible fence, regardless of the social utility of his use. The livestock owner could avoid trespass liability only by enclosing his animals within his own physical fence.

A wave of early nineteenth-century state statutes, however, appeared to reject the English "fence-in" rule in favor of a new "free-range" standard, which allowed stock to roam freely over private land without creating trespass liability. ${ }^{163}$ In the context of wilderness land, stock owners maintained that the broad application of these statutes was essential to facilitate development. As a Massachusetts attorney argued in 1809, "[f]or want of proper pasture land, it was absolutely necessary that the cattle should be permitted to go at large in the forests for subsistence; and from the sparseness of the settlements, and the scarcity of inhabitants, it was impossible to watch them." 164 Similarly, a Maine attorney complained in 1828 that the English rule would "arrest or at least impede the settlement of our wild lands, and be highly injurious to infant settlements, where cattle must from the necessity of the case, be permitted to range without fences." ${ }^{\prime 165}$ Nonetheless, the earliest American decisions-largely in New England states-circumvented the seemingly plain mandates of these statutes by construing them narrowly. Concluding that the free-range statutes superseded traditional common law only as between adjoining landowners, these first courts followed the English approach that "[e]very man at his peril is bound to keep his cattle on his own close ${ }^{166}$ in all other situations. ${ }^{167}$

${ }_{163}$ See, for example, Seeley v Peters, $10 \mathrm{Ml}$ (5 Gilm) 130, 141-42, 143 (1848) ("There are numerous [ ] legislative Acts clearly [establishing] that cattle were permitted to run at large . . . ."); Kerwhacker v Cleveland, Columbus, \& Cincinnati R.R. Co., 3 Ohio St 172, 179 (1854) ("[I]t has never been understood by [the people of Ohio] that they were tort feasors, and liable in damages for letting their stock [ ] run at large."); Jones $v$ Witherspoon, $52 \mathrm{NC}$ (7 Jones) 555, 557 (1860) (denying recovery to plaintiff for damages caused by trespass of defendant's livestock on plaintiff's land).

${ }_{164}$ Rust, 6 Mass at 93.

${ }^{165}$ Little $v$ Lathrop, $5 \mathrm{Me} \mathrm{356,} 361$ (1828).

${ }^{166}$ Coxe, $9 \mathrm{NJ} \mathrm{L}$ at 385. Compare Rust, 6 Mass at 91-92 (counsel arguing that freerange act only altered common law "as between owners of adjoining closes").

167 For cases allowing for trespass damages if livestock damage areas other than adjoining land, see Little, 5 Me at 359; Stackpole v Healy, 16 Mass 33, 38 (1819); Rust, 6 Mass at 90, 95-96; Lawrence $v$ Combs, $37 \mathrm{NH}$ 331, 335-36 (1858); Coxe, 9 NJ L at 386-87; Chambers v Matthews, 18 NJ L 368, 369 (1841); Wilder $v$ Wilder, 38 Vt 678, 681 (1866). But see Studwell v Ritch, 14 Conn 292, 295 (1841) (The Connecticut law requiring landowners "to enclose [cattle], by a lawful fence ... grew out of the situation of the country at the time of the first settlement of this state," including the practice of allowing cattle "to roam over the uninclosed lands, and obtain a subsistence wherever they could."); Knight $v$ Abert, $6 \mathrm{~Pa} 472,472$ (1847) (noting that in Pennsylvania an owner of cattle "is 
A cluster of midcentury decisions from states west of the Appalachian Mountains interpreting similar statutes, however, foreshadowed the victory of the free-range rule. Concluding that the English rule had never been in force in their states, these courts reasoned, in part, that local wilderness conditions mandated a uniquely American standard. The Illinois Supreme Court, for example, declared that "[h]owever well adapted the rule of the Common Law may be to a densely populated country like England, it is surely but ill adapted to a new country like ours"1168 where settlers "have located themselves contiguous to prairies for the very purpose of getting the benefit of the range."169 The court reasoned that unless settlers were allowed to exercise their "universally conceded" right of grazing their cattle upon "uninclosed ground," the "luxuriant growth" of extensive prairies "must be suffered to rot and decay where it grows.".170 The twin themes that free grazing was accepted as custom and necessary to encourage the economic use of wilderness areas ultimately emerged from decisions in the midwest, ${ }^{171}$ south, ${ }^{172}$ and west that similarly legitimized livestock trespasses. ${ }^{173}$

not liable to an action for their browsing on his neighbour's unenclosed woodland" because, inter alia, "it is better that all waste lands should be treated as common without stint").

${ }^{169}$ Seeley, $10 \mathrm{Il}$ at 141-42.

16 Id at 142.

170 Id. Courts frequently noted that vegetation valuable for grazing would be wasted under the common law approach. See, for example, Morris v Fraker, 5 Colo 425, 429 (1880) (noting that if "the grasses which grow thereon are not depastured, they will waste and decay").

${ }^{131}$ See, for example, Kerwhacker, 3 Ohio St at 178-79 (following free-range rule); Wagner $v$ Bissell, 3 Iowa 396, 409 (1856) (same).

${ }_{172}$ See, for example, Nashville \& Chattanooga Railroad Co. v Peacock, 25 Ala 229, 232 (1854) (concluding that "the unenclosed lands of this State are to be treated as common pasture for the cattle and stock of every citizen"); Vicksburg \& Jackson Railroad Co. $v$ Patton, 31 Miss 156, 185 (1856) (explaining that because Mississippi is "sparsely populated, with large bodies of woodlands and prairies, which have never been enclosed," these lands were understood by all to be "common of pasture"); Jones, $52 \mathrm{NC}$ at 557 (noting that the common law view, "if it were ever recognized in our waste and thinly populated country, has been long since abrogated by various legislative acts and by constant usage to the contrary"). See also L.R. \& F.S. Railway Co. v Finley, 37 Ark 562, 568 (1881) (noting that the common law rule "has never been recognized in this State" due to the "condition and circumstances of our people" in that, when the country was first settled, "there was [too] much land lying waste and unenclosed"); Poindexter $v$ May, 98 Va 143, 34 SE 971, 972 (1900) (observing that the common law rule has never been in effect, based on colonial statutes as early as 1631); Haigh $v$ Bell, $41 \mathrm{~W}$ Va 19, 23 SE 666, 667 (1895) (acknowledging that state rejected common law rule).

${ }_{173}$ See, for example, Fant $v$ Lyman, 9 Mont 61, 22 P 120, 121 (1889) (noting that even if the defendant drove his sheep onto plaintiffs' land for the "purpose of pasturage," the defendant "had the right to pasture domestic animals on unenclosed lands"). 
Nineteenth-century courts repeatedly found the free-range tradition, whether described as a "universal acceptation," a "general custom," tom,"176 well suited to American conditions, where states were "sparsely populated, with large bodies of woodlands and prairies"177 and had "so much land lying waste and uninclosed."178 As the Ohio Supreme Court expressed it, "to leave uncultivated lands uninclosed was an implied license to cattle and other stock at large to traverse and graze them."179 This movement gained momentum throughout the balance of the century, until the freerange rule ultimately prevailed in most states. ${ }^{180}$

In effect, American courts envisioned privately owned wilderness as common property for purposes of public grazing. ${ }^{181}$ Thus, in an 1889 decision extending the free-range rule to government lands, the Supreme Court observed that for decades the "universal custom" had been that "[e]verybody used the open unenclosed country, which produced nutritious grasses, as a public common on which their horses, cattle, hogs and sheep could run and graze." ${ }^{182}$ The owner of unenclosed wilderness

174 Vicksburg \& Jackson Railroad Co., 31 Miss at 186.

175 Kerwhacker, 3 Ohio St at 179.

376 L.R. \& F.S. Railway Co., 37 Ark at 568.

177 Vicksburg \& Jackson Railroad Co., 31 Miss at 185.

178 L.R. \& F.S. Railway Co., 37 Ark at 568.

179 Kerwhacker, 3 Ohio St at 180.

180 See Robert C. Ellickson, Of Coase and Cattle: Dispute Resolution Among Neighbors in Shasta County, 38 Stan I Rev 623, 660 n 94 (1986) (concluding, based on review of nineteenth-century treatises, that the free-range standard became the majority rule).

${ }^{181}$ As the court explained in Tennessee, Alabama \& Georgia Railway Co. v Andrews:

[I]n the early days of this country it became the general custom to allow cattle, horses, hogs and the like to roam and range at large on the uninclosed lands of the neighborhood in which they were kept, making them quasi commons. This was due to the great value of the uninclosed lands as pasturage for these animals, and to the scarcity and high cost of fencing. Consequently, the common law rule was rejected....

117 Ga App 164, 159 SE2d 460, 462 (1968). See also Valerie W. Scott, The Range Cattle Industry: Its Effect on Western Land Law, 28 Mont L Rev 155, 159-71 (1967) (observing that between "1865 and 1900 the land laws and policies of the United States government did not permit the rancher legally to acquire enough grazing land to operate a profitable beef raising business," and discussing various mechanisms by which ranchers acquired additional grazing rights); Grossfeld, 82 Mich L Rev at 1515-17 (cited in note 17) (discussing the effect of geography on fencing issues).

${ }_{182}$ Buford v Houtz, 133 US 320, 327-28 (1889). The Buford court emphasized the economic importance of allowing settlers to "graze their stock upon the grasses of the prairies" both "upon the public lands of the United States, and upon the unenclosed lands of the private individual." Id at 327. It explained that the English rule was "ill-adapted to 
land in the United States had little choice but to tolerate the damage caused by his neighbor's livestock. ${ }^{183}$

b. Nuisance. In contrast to the resounding transfiguration of trespass, the nineteenth-century judicial reaction to English nuisance law was muted. Blackstone's definition of a private nuisance as "anything done to the hurt or annoyance of the lands, tenements or hereditaments of another" ${ }^{\prime 184}$ reflected the central concern of the rigid English rule: preventing interference with existing productive land uses. Virtually any conduct that injured another's land was considered a nuisance, regardless of accompanying circumstances. ${ }^{185}$ Harm was the sole criterion for

the nature and condition of the country" at the time of settlement, "[o]wing to the scarcity of means for enclosing lands, and the great value of the use of the public domain for pasturage." Id at 328.

183 Another example of the American transformation of English trespass law in the wilderness context is found in decisions involving hunters, where the doctrine of implied license was expanded to legitimate the custom of trespass. As Justice Holmes explained in McKee v Gratz:

The strict rule of the English common law as to entry upon a close must be taken to be mitigated by common understanding with regard to the large expanses of unenclosed and uncultivated land in many parts at least of this country. Over these it is customary to wander, shoot and fish at will until the owner sees fit to prohibit it. A license may be implied from the habits of the country.

260 US 127, 136 (1922). See also Bizzell v Booker, 16 Ark 308, 320 (1855) (concluding that hunting in a privately owned wilderness area did not constitute a trespass, and noting that the rule originated because, inter alia, "[d]rafts upon the forest game, are also often required to supply the wants of the pioneer, under the contingencies and inconveniences of a sparsely inhabited country"); Payne $v$ Gould, 74 Vt 208, 52 A 421, 421 (1902) (citing provision from Vermont constitution that citizens "shall have the liberty in seasonable times to hunt and fowl on the lands they hold, and on other lands not inclosed").

184 Ehrlich, ed, Ehrlich's Blackstone at 581 (cited in note 13).

ix The absolutist nature of the English rule is epitomized by the House of Lords decision in St. Helen's Smelting Co. $v$ Tipping, 11 Eng Rep 1483 (HL 1865) (appeal taken from CA). In that case, the defendant's smelting factory emitted "noxious gases, vapours, and other noxious matter" which injured, inter alia, "hedges, trees, shrubs, fruit, and herbage" on plaintiff Tipping's 1,300-acre estate. Id at 1483. At the trial of the plaintiff's nuisance action, the defendant introduced evidence that "the whole neighbourhood was studded with manufactories and tall chimneys." Id at 1484. Following a jury verdict for the plaintiff, the defendant appealed, arguing that the factory could not be deemed a nuisance because it operated in an industrial area, which was a suitable locality. Arguing before the House of Lords, even the defendant's counsel conceded that "[ $t$ ]he law on this subject is doubtful, and requires to be settled by the authority of this House." Id. The Lord Chancellor noted that the jury had found "the existence of the injury" and that the defendant's "only ground" for a new trial was its assertion that "inasmuch as this copper smelting is carried on in . . . a fit place, it may be carried on with impunity, although the result may be the utter destruction ... of the value of the Plaintiff's property." Id at 1487. Joined by Lords Cranworth and Wensleydale, the Chancellor rejected the proposed 
liability.

Although early American courts typically followed the harmbased rule, ${ }^{186}$ a more flexible approach eventually surfaced under which only an unreasonable land use was deemed a nuisance. The most notable feature of this new standard was its emphasis on locality. Courts increasingly considered the nature of the locality, among other factors, in determining both whether a nuisance existed and, if so, whether it should be enjoined. ${ }^{187}$ All other things being equal, conduct was less likely to be enjoined as a nuisance if it occurred in a wilderness area than in another, more developed, locality.

Many nineteenth-century American courts incorporated the locality analysis into the nuisance standard itself, by considering the nature of the property in determining whether the disputed use was unreasonable. ${ }^{188}$ A slaughterhouse, for example, would

locality standard in the context of nuisances causing property damage:

My Lords, I apprehend that that is not the meaning of the word 'suitable,' or the meaning of the word 'convenient,' which has been used as applicable to the subject. The word 'suitable' unquestionably cannot carry with it this consequence, that a trade may be carried on in a particular locality, the consequence of which trade may be injury and destruction to the neighbouring property.

Id. See also Daniel R. Coquillette, Mosses from an Old Manse: Another Look at Some Historic Property Cases about the Environment, 64 Cornell L Rev 761, 782-92 (1979) (discussing misinterpretations of St. Helen's Smelting Co.).

${ }_{126}$ For example, the analysis of nuisance in one of the most popular early American treatises, Nathan Dane's General Abridgement and Digest of American Law, essentially repeated Blackstone's language. Compare Nathan Dane, 3 General Abridgement and Digest of American Law 39, 44 (Cummings, Hilliard 1824), with Ehrlich, ed, Ehrlich's Blackstone at 581-82 (cited in note 13). Moreover, American decisions occasionally relied directly on Blackstone. See, for example, Burditt $v$ Swenson, 17 Tex 489, 502 (1856) (extensively citing Blackstone on nuisance).

${ }_{187}$ See generally Paul M. Kurtz, Nineteenth Century Anti-Entrepreneurial Nuisance Injunctions-Avoiding the Chancellor, 17 Wm \& Mary L Rev 621 (1976) (discussing the nineteenth-century evolution of American nuisance law); Horwitz, Transformation of American Law at 74-78 (cited in note 12) (same).

${ }_{183}$ See, for example, Whitney $v$ Bartholomew, 21 Conn 213, 218 (1851) (observing that whether an activity constitutes a nuisance "must depend much upon the nature of the business there done, and of its proximity to the residences and property of others. ... And from this it results, that of trades which are lawful, some may be nuisances in cities, which are harmless in the country."); Owen $v$ Phillips, 73 Ind 284, 295-96 (1881) ("We approve, in its fullest extent, the doctrine, that in some localities a business will be considered a nuisance, while it would not be so in others."); Campbell v Seaman, $63 \mathrm{NY}$ 568,577 (1876) ('[W] any certain general rules, but must depend upon the circumstances of each case. A use of property in one locality and under some circumstances may be lawful and reasonable, which, under other circumstances, would be unlawful, unreasonable and a nuisance."); Huckenstine's Appeal, $70 \mathrm{~Pa} 102,106-107$ (1871) (noting that in determining whether 
be deemed a nuisance in a populated city, but not on "vacant ground" in the country. ${ }^{189}$ Because wilderness was seen as having little value, it received the least protection of any land category under this emerging standard. As the North Carolina Supreme Court observed in 1856, if a grist mill were "built in a wilderness [ ] there [would be] no one to be injured either in health or property," and, thus, there would be no nuisance. ${ }^{190}$ This approach inevitably tended to encourage the development of noxious uses on wilderness lands in the interest of evading nuisance liability. Thus, when a gunpowder storehouse was situated in countryside described as "wild and broken as to its general surface, ... traversed by numerous ravines and hills, and altogether possess[ing] a romantic and secluded aspect," the Pennsylvania Supreme Court commented that "it is doubtful if a better location could be made in Allegheny County."191

Other courts, although finding nuisance liability under the traditional harm-based standard, denied effective relief in cases involving wilderness. While nineteenth-century English courts enjoined nuisances with increasing frequency, ${ }^{192}$ American courts often refused injunctive protection for wilderness lands, reasoning that they were essentially valueless. ${ }^{193}$ The owner of an "un-

smoke and gases which injured, inter alia, plaintiff's grape vines and fruit trees constituted a nuisance, "the customs of the people, the characteristics of their business, the common uses of property and the peculiar circumstances of the place" must be considered). Compare Fertilizing Co. $v$ Hyde Park, 97 US 659, 664 (1878) (observing that a fertilizer plant, originally built in a region which was "swampy and nearly uninhabited, giving little promise of further improvement" became an "unendurable nuisance" as settlement in the area increased). See also Joseph A. Joyce and Howard C. Joyce, Treatise on the Law Governing Nuisances $\$ 95$ at 141-42 (Matthew Bender 1906) (generally discussing locality as a factor in determining whether a nuisance exists).

${ }_{189}$ Brady $v$ Weeks, 3 Barb 157, 159 (NY Sup Ct 1848). See also Howard $v$ Lee, 5 NY Super Ct 281, 283 (1849) (commenting that "all trades which render the enjoyment of life and property uncomfortable, must ... be conducted in the outskirts of the city or in the country").

150 Wilder v Strickland, 55 NC (2 Jones Eq) 386, 391 (1856).

191 Dilworth's Appeal, $91 \mathrm{~Pa} 247,251-52$ (1879).

192 See George D. Watrous, Torts 1701-1901, in Two Centuries' Growth of American Law 1701-1901 83, 98-100 (Scribner's Sons 1901).

${ }_{193}$ See, for example, Coe $v$ Winnepisiogee Lake Cotton and Woolen Manufacturing Co., $37 \mathrm{NH} 254,264$ (1858) (holding owner of farm adjoining lake and "woodlands on certain island therein" not entitled to an injunction against project which would lower the lake level, and noting that "the destruction of the plaintiff's grass and timber" was not injury of "that ruinous and irremediable character to constitute a case of pressing necessity for arresting them"); Madison v Ducktown Sulphur Copper \& Iron Co., 113 Tenn 331, 83 SW $658,659,667$ (1904) (refusing to enjoin emission of noxious smoke by copper smelter that damaged "thin mountain lands, of little agricultural value"). See generally John Merryman, The Defense of Unoccupied Property Against Nuisance, 21 Notre Dame L Rev 358 (1946) (discussing a sharp judicial split on the analogous issue of whether a nuisance 
improved woodlot" in Massachusetts, for example, sought an injunction against operation of a "noxious and offensive" woolcleansing factory, alleging that its activities caused "corruption of the water" in the stream flowing through his land. ${ }^{194}$ Emphasizing that the plaintiff had never used the property "for a residence or a pasture," however, the court concluded that he had not suffered the irreparable injury necessary for an injunction. ${ }^{195}$ Similarly, the owner of a parcel of New Jersey land "so wet, marshy and sour as to be worthless for agricultural ... purposes" was unable to enjoin a proposed dam that would have allowed "the wet lands [to be] reclaimed and made arable and productive."196

Absent injunctive relief, nuisance proved a useless doctrine to owners of wilderness land. The alternative remedy of damages was available in theory, but the measure of damages was premised on the extent to which the nuisance had reduced the market value of the property. ${ }^{197}$ Because the market valued wilderness land solely in terms of its potential for future exploitative use, the alteration of its natural condition by a nuisance frequently had no meaningful impact on value.

\section{WILDERNESS AND MODERN PROPERTY LAW}

\section{A. The Wilderness Thesis Revisited}

Modern American property law remains hostile to preservation of privately owned wilderness. If we imagine a continuum between the two extremes of total wilderness destruction and total wilderness preservation, the property-law system still tilts sharply toward destruction. All other things being equal, the system tends to resolve use and title disputes concerming such land by favoring the exploiter over the preserver.

The instrumentalist judges who created an independent American property law confronted a national landscape dominat-

affecting vacant land-typically farmland or developed lots-can be enjoined). Looking back from the perspective of the early twentieth century-while refusing to enjoin operation of a copper smelter that had allegedly "injured and killed the timber and trees for many miles around..., rendering the valley barren"-a Montana court rejoiced that "[w] hat was a wilderness less than half a century ago has, principally through the development of mineral wealth, become a scene of energy and restless activity." Bliss $v$ Anaconda Copper Mining Co., 167 F 342, 345, 369 (C C D Mont 1909).

194 Harris $v$ Mackintosh, 133 Mass 228, 228-29 (1882).

195 Id at 232.

196 McNeal v Assiscunk Creek Meadow Co., 37 NJ Eq 204, 205, 209 (1883).

197 See generally Joyce and Joyce, Law Governing Nuisances $\$ 489$ at 710-11 (cited in note 188) (discussing measure of damages for permanent nuisances). 
ed by wilderness. Over the next two centuries, the property-law system they crafted undoubtedly contributed to the destruction of millions of wilderness acres. ${ }^{198}$ But the era of wilderness abundance ended long ago. Today, despite a fundamentally different national landscape, the property-law system still actively facilitates the despoliation of our scattered wilderness remnants.

\section{B. Wilderness in Modern America}

The environmental history of the United States is dominated by the destruction of the pre-Columbian wilderness. The federal government transferred most of the vast public domain into private ownership during the nineteenth century, ${ }^{199}$ and encouraged private exploitation of the remaining public lands. ${ }^{200}$ As two hundred years of development transformed the national landscape, the pristine American wilderness slowly ebbed away. ${ }^{201}$

Every square mile of the nation has felt the human hand. For example, although virgin forest once covered over half of the country, no more than 5 percent of this forest remains; ${ }^{202}$ only

188 The extent to which the property-law system affected the destruction of American wilderness cannot be quantified with any degree of precision. As discussed in the text accompanying notes 247-319, however, the routine application of the six doctrines analyzed herein in thousands of cases over the last two hundred years tended to either directly allow wilderness destruction or facilitate vesting title to wilderness land in an exploitative owner, which indirectly produced the same result.

1s9 Approximately two-thirds of the publicly owned nineteenth-century American wilderness passed into private ownership. The territory of the original thirteen states occupied roughly 266 million acres. See 16th CEQ Report at 34 (cited in note 2). The balance of the land surface of the continental United States-1.63 billion acres of wilderness-was all within the public domain during portions of the nineteenth century. See id; Arthur B. Daugherty, Major Uses of Land in the United States: 198714 table 14, 20 app table 1 (Dept Agriculture 1987). By 1987, however, only 517 million acres of land within the continental United States were owned by federal, state or local governments. Id at 14 table 14. Thus, approximately 1.113 billion acres were transferred into private ownership between 1800 and the present.

${ }^{200}$ For a historical description of the manner in which the federal government encouraged private exploitation of publicly owned wilderness lands, see Gates, Public Land Law at 563-698 (cited in note 40). See also Randal O'Toole, Reforming the Forest Service 6-8 (Island 1988) (arguing that the U.S. Forest Service still facilitates degradation of public lands by selling timber and grazing rights at below-market prices); Charles F. Wilkinson, Crossing the Next Meridian: Land, Water, and the Future of the West (Island 1992) (generally discussing prodevelopment policies affecting public lands in the western United States).

${ }^{201}$ See notes text accompanying 202-08. The fragmentation of the American wilderness between 1800 and the present is perhaps best summarized by a single statistic: today "there is no place in the contiguous forty-eight states farther than 21 air miles from a constructed road." Foreman and Wolke, Big Outside at 20 (cited in note 3).

${ }^{202}$ Department of the Interior, Biological Rep 28, Endangered Ecosystems of the 
10 percent of the tallgrass prairie that formerly symbolized the Midwest still exists; ${ }^{203}$ most of the nation's wetlands have vanished. ${ }^{204}$ Even the wilderness that remains has been affected by human activity to some extent, through media such as air pollution, logging, introduction of nonnative species, and livestock grazing. ${ }^{205}$

The modern American wilderness consists of lands that-while slightly affected by human activity-still appear to be in primeval condition, and betray no significant sign of human impact. ${ }^{206}$ Two standards are useful in assessing how much wil-

United States: A Preliminary Assessment of Loss and Degradation 37 (1995).

203 Id at 43.

${ }^{204}$ See Council on Environmental Quality, Environmental Quality: The Twenty-Second Annual Report of the Council on Environmental Quality, 304-05 table 64 (1992) ("22d CEQ Report").

${ }_{205}$ "In essence, the American wilderness of the 1990 s, grand though it is, is wilderness with an asterisk." Foreman and Wolke, Big Outside at $11 \mathrm{n} 9$ (cited in note 3). See also John C. Hendee, George H. Stankey, and Robert C. Lucas, Wilderness Management 200 (US Forest Service 1978) ("At the outset we must recognize there are no completely unaltered ecosystems left on this planet. The effects of modern man and his products are pervasive.").

Air pollution, for example, has affected most wilderness areas. Ozone damage has "been detected in forests across the country," including those in Yosemite, Kings Canyon, Great Smoky Mountains, and Shenandoah national parks. Martin Forstenzer, Ozone Damage to Forests: The Effects of Sprawl and Smog, Audubon 16, 16 (July-Aug 1994). The black cherry tree, for example, "has sustained ozone injury throughout its range from Maine to northern Florida." Id. Similarly, the emission of sulfur oxides and nitrogen oxides from fossil fuel combustion, primarily from midwestern power plants, has contributed to increasingly acidic rain, which injures plants and wildlife in the eastern United States. See Andrew Goudie, The Human Impact on the Natural Environment 277-78 (MIT 2d ed 1986).

Nonnative plant and animal species have supplanted native species in many regions. For example, the introduction of European species of grass has contributed to the loss of 99 percent of the native grassland in California. See Department of the Interior, Endangered Ecosystems at 45 (cited in note 202); Alfred W. Crosby, Ecological Imperialism: The Biological Expansion of Europe, 900-1900 152-54, 158-59, 290-91 (Cambridge 1986) (discussing the effect of the introduction of European plant species to California and the Great Plains). See also id at 292-93 (commenting on how European settlement allowed the newly introduced sparrow and starling to flourish at the expense of the indigenous passenger pigeon).

Similarly, 99 percent of the sagebrush steppe that dominates the Intermountain West and Far West regions of the country has been affected by stock grazing. See Department of the Interior, Endangered Ecosystems at 47.

${ }^{206}$ As Aldo Leopold, the foremost modern advocate of wilderness preservation, observed:

Wilderness is the raw material out of which man has hammered the artifact called civilization.

Many of the diverse wildernesses out of which we have hammered America are already gone; hence in any practical program the unit areas to be preserved must vary 
derness remains: "statutory wilderness" and "de facto wilderness." ${ }^{207}$ Depending on which yardstick is utilized, between 10 and 20 percent of the continental United States may today be characterized as wilderness. A substantial portion of this wilderness-perhaps as much as half-is privately owned. ${ }^{208}$

The concept of "statutory wilderness" stems from the Wilderness Act of 1964, which formally protects large tracts of publicly owned "wilderness." ${ }^{\text {"209 }}$ Reversing its prior policy of encouraging unchecked exploitation of public lands, during the twentieth century the federal government gradually moved toward safeguarding its remaining wild lands. ${ }^{210}$ Pursuant to the Wilderness Act, which culminated this effort, ${ }^{211}$ approximately 2 percent of the contiguous United States is designated for permanent preservation as wilderness. ${ }^{212}$ The statutory definition of "wil-

greatly in size and ... wildness.

Aldo Leopold, Wilderness, in Aldo Leopold, A Sand County Almanac: With Other Essays on Conservation from Round River 241, 241-42 (Oxford 1966).

207 See note 1.

${ }_{20.9}$ Using the de facto wilderness standard, as much as half the remaining wilderness in the continental United States may be privately owned. Private rangeland occupies 404 million acres, while private forest land (including forest land used for grazing) spans 393 million acres. See Daugherty, Major Uses of Land at 14 table 14 (cited in note 199). Using the standard assumptions for rangeland and forest land in the calculation of total de facto wilderness, see note 220 , approximately 12 million acres of rangeland and over 100 million acres of forest land are privately owned de facto wilderness. In addition, approximately 50 million acres of marshes, swamps, sand dunes, rock, desert, tundra, and similar "miscellaneous" land constituting de facto wilderness are private property. Id at 3 table 2 , 14. Thus, over 162 million acres of land-at least 9 percent of the continental United States-is occupied by privately owned de facto wilderness. The amount of privately owned statutory wilderness is smaller, though still substantial. See note 214.

${ }^{209} 16$ USC $\S \S 1131$ et seq (1994).

210 The federal government's involvement in wilderness preservation dates from 1872, when President Grant set aside over two million acres as Yellowstone National Park. Nash, Wilderness and the American Mind at 108 (cited in note 34). During the early twentieth century, a federal policy favoring limited wilderness preservation coalesced slowly, in large part due to the efforts of Aldo Leopold and Bob Marshall. For a description of the evolving federal preservation effort, see id at 182-237.

${ }^{211}$ In enacting the Wilderness Act, Congress formally acknowledged the importance of wilderness preservation:

In order to assure that an increasing population, accompanied by expanding settlement and growing mechanization, does not occupy and modify all areas within the United States and its possessions, leaving no lands designated for preservation and protection in their natural condition, it is hereby declared to be the policy of the Congress to secure for the American people... the benefits of an enduring resource of wilderness.

16 USC $\S 1131$ (a). See generally Michael McCloskey, The Wilderness Act of 1964: Its Background and Meaning, 45 Or L Rev 288 (1966).

${ }^{212}$ Within the contiguous forty-eight states, federally designated "Wilderness Areas" 
derness" focuses primarily on the elements of parcel size and apparent wildness: "an area of undeveloped ... land retaining its primeval character and influence ... which . . . generally appears to have been affected primarily by the forces of nature, with the imprint of man's work substantially unnoticeable ... [and] is at least five thousand acres." ${ }^{213}$ Applying this standard, statutory wilderness (including both existing public land and private wilderness that the federal government could purchase ${ }^{214}$ covers approximately 9 percent of the contiguous United States. ${ }^{215}$ Most of the land potentially eligible for preservation under the Wilderness Act, then, lacks formal protection. ${ }^{216}$

occupy 38,510,898 acres. See Patricia Byrnes and Burnita Bell, 30 Years of Wilderness, Wilderness 2, 3-9 (Fall 1994). State wilderness preservation programs-notably in California, Maine, and New York-also protect significant acreage. See generally Hendee, Stankey, and Lucas, Wilderness Management at 130-32 (cited in note 205) (describing state wilderness programs).

${ }_{213}$ The complete definition of "wilderness" in the Wilderness Act is both poetic and redundant:

A wilderness, in contrast with those areas where man and his own works dominate the landscape, is hereby recognized as an area where the earth and its community of life are untrammeled by man, where man himself is a visitor who does not remain. An area of wilderness is further defined to mean in this chapter an area of undeveloped Federal land retaining its primeval character and influence, without permanent improvements or human habitation, which is protected and managed so as to preserve its natural conditions and which (1) generally appears to have been affected primarily by the forces of nature, with the imprint of man's work substantially unnoticeable; (2) has outstanding opportunities for solitude or a primitive and unconfined type of recreation; (3) has at least five thousand acres or is of sufficient size as to make practicable its preservation and use in an unimpaired condition; and (4) may also contain ecological, geological, or other features of scientific, educational, scenic, or historical value.

Wilderness Act of $1964, \S 2(c)$, Pub L No 88-577, 78 Stat 890, 891, codified with some differences in language at 16 USC $\$ 1131(\mathrm{c})$.

234 Privately owned land that would qualify as statutory wilderness-and thus could be included in a federally protected wilderness area only if it were purchased by or donated to the federal government-is extensive but difficult to quantify. One effort to identify the remaining unprotected "big wilderness" areas in the United States (defined as at least one hundred thousand acres in the West, and at least fifty thousand acres in the East), catalogued large blocks of privately owned statutory wilderness in twenty-eight states. See Foreman and Wolke, Big Outside 20, 47-437 (cited in note 3). For example, in Maine alone this study identified over eight hundred thousand acres of privately owned land suitable for purchase as components of federal wilderness areas. Id at 405-10. However, because it did not consider privately owned parcels between five thousand acres (the typical minimum for statutory wilderness) and its "big wilderness" thresholds of one hundred thousand and fifty thousand acres, this study cannot be considered a complete inventory of privately owned statutory wilderness.

215 Id at 20.

216 Other federal lands are protected to some extent, primarily as components of the National Park System, the National Wildlife Refuge System, and the National Wild and 
Moreover, even tracts of land smaller than five thousand acres-normally ineligible for protection under the Wilderness Act-possess wilderness value. ${ }^{217}$ This value is recognized by

Scenic Rivers System. Although not subject to the "considerably stricter preservation standards" mandated by the Wilderness Act, these lands are generally shielded from mining, logging, grazing, and most other exploitative uses. George C. Coggins and Robert L. Glickman, 2 Public Natural Resources Law $\S 14.01,14.02(2)(c), 14.03,15.02(1)$ at 14-3, 14-8, 14-14, 15-3 (Clark Boardman Callaghan 1990). Nevertheless, even the limited uses permitted in these regions are troubling from the preservationist standpoint.

Our splendid National Park System, for example, is still premised on the twin pillars of conservation and recreation: "to conserve the scenery and the natural and historic objects and the wild life therein and to provide for the enjoyment of the same in such manner and by such means as will leave them unimpaired for the enjoyment of future generations." 16 USC $\$ 1$ (1994). Yet, as Roderick Nash suggests, our National Parks are at "the point of being loved to death." Nash, Wilderness and the American Mind at 319, 325-41 (cited in note 34). See generally Joseph Sax, Mountains Without Handrails: Reflections on the National Parks (Michigan 1980) (analyzing the conflict between preservation and tourism in National Parks). At some point, human use is inconsistent with preservation. "Wilderness values are such that even appropriate kinds of recreational use can, in sufficient quantity, destroy the wildness of a place." Nash, Wilderness and the American Mind at 317. See, for example, Wilderness Public Rights Fund v Kleppe, 608 F2d 1250 (9th Cir 1979) (upholding administrative issuance of permits for boating in Grand Canyon National Park); National Wildlife Federation v National Park Service, 669 F Supp 384 (D Wyo 1987) (upholding administrative decision allowing continued use of Fishing Bridge Campground in Yellowstone National Park despite its location in grizzly bear habitat).

Similarly, although the National Wildlife Refuge System exists "for the primary purpose of developing a national program of wildlife and ecological conservation and rehabilitation," United States Fish and Wildlife Service, National Wildlife Refuge System, 50 CFR § 25.11(b) (1994), uses such as "hunting, fishing, public recreation and accommodations" may be allowed. 16 USC $\S 668 \mathrm{dd}(\mathrm{d})(1)(\mathrm{A})$ (1994). See, for example, Humane Society of the United States $v$ Lujan, 768 F Supp 360 (D DC 1991) (upholding administrative decision allowing public deer hunting in the Mason Neck National Wildlife Refuge). See also Richard J. Fink, The National Wildlife Refuges: Theory, Practice, and Prospect, 18 Harv Envir L Rev 1, 63-76 (1994) (discussing difficulties in protecting National Wildlife Refuges from human impacts).

Finally, the National Wild and Scenic Rivers System is required by statute to be "administered in such manner as to protect and enhance the values which caused it to be included in said system without, insofar as is consistent therewith, limiting other uses that do not substantially interfere with public use and enjoyment of these values." 16 USC $\S$ 1281(a) (1994). Even under this standard, however, cattle grazing and jet boating are common within the System. See Peter M.K. Frost, Protecting and Enhancing Wild and Scenic Rivers in the West, 29 Idaho L Rev 313, 327-29 (1992).

${ }^{217}$ Parcel size is not a litmus test for wilderness. Even the definition of "wilderness" in the Wilderness Act itself recognizes that a tract smaller than 5,000 acres can qualify for wilderness status if it "is of sufficient size as to make practicable its preservation and use in an unimpaired condition." 16 USC $\$ 1131$ (c). Indeed, many components of the National Wilderness Preservation System are comparatively small, including Baboquivari Peak, Arizona (2,040 acres); Big Lake, Arkansas (2,144 acres); Platte River, Colorado (743 acres); Cedar Keys, Florida (379 acres); Panther Den, Illinois (685 acres); Monomoy, Massachusetts (2,420 acres); Huron Islands, Michigan (147 acres); Tamarac, Minnesota (2,180 acres); Leaf, Mississippi (994 acres); Pond Pine, North Carolina (1,685 acres); Hell Hole Bay, South Carolina (2,125 acres); and Little Dry Run, Virginia (2,858 acres). See Byrnes 
the alternative "de facto wilderness" standard, which reflects the working definition of "wilderness" used by modern courts to characterize tracts of wild, undeveloped land outside of the Wilderness Act context. ${ }^{218}$ Although not well delineated, this judicial usage tends to focus on apparent wildness with little regard for parcel size. Any parcel of undeveloped land that appears to be substantially in natural condition, with no significant human imprint, may be considered de facto wilderness. ${ }^{219}$ Under this standard, roughly 20 percent of the coterminous United States is wilderness. ${ }^{220}$

and Bell, 30 Years, Wilderness at 3-8 (cited in note 212). State wilderness systems generally demonstrate greater flexibility on parcel size. The Maryland Wildlands Preservation System Act, Md Nat Res Code Ann § 5-12-3 (Supp 1995), for example, uses a threshold size of 500 acres. See Hendee, Stankey, and Lucas, Wilderness Management at 131 (cited in note 205).

${ }^{218}$ See, for example, Larini v Biomass Industries, 918 F2d 1046, 1048, 1050 (2d Cir 1990 ) (referring to 900 acres of privately owned "woods" as "wilderness"); Stanley Works $v$ Commissioner of Internal Revenue, 87 Tax Ct 389, 390 (1986) (characterizing an undeveloped 2,200-acre river front parcel in northwestern Connecticut as "essentially a wilderness area"); Trustees of Vermont Wild Land Foundation v Town of Pittsford, $137 \mathrm{Vt} \mathrm{439,}$ 407 A2d 174, 176 (1979) (referring to 2,100 acres of privately owned wooded land as an undeveloped section of wilderness"). Similarly, a number of courts have explained why certain private lands cannot be considered "wilderness." See, for example, Dumaine Farms $v$ Commissioner of Internal Revenue, 73 Tax Ct 650, 653 (1980) (noting that the farm involved was not "part of an ecologically significant undeveloped area such as a swamp, marsh, forest, or other wilderness tract"); $V$ \& S Planting Co. $v$ Red River Waterway Commission, 472 S2d 331, 335 (La Ct App 1985) ("[T]his was not a wilderness area; it was an old field which was overgrown by thorn bushes and from which all the pecan trees had been cut for logs a few years earlier and was littered and strewn with tree tops."); McMullen v Dowley, 418 A2d 1147, 1153 (Me 1980) (rejecting the claim that a fenced woodlot adjacent to a highway was "in a wilderness state"). Compare McKenna $v$ City of Fort Wayne, 429 NE2d 662, 663, 665-66 (Ind Ct App 1981) (rejecting the assertion that a public park where natural grass was periodically cut could be considered a wilderness: "[o]rdinarily, one does not mow 'wilderness").

${ }_{219}$ This standard, like the statutory wilderness test, is premised on apparent-not absolute-wildness. It is accordingly possible that developed land, once abandoned, could revert to de facto wilderness over a sufficiently long period. See note 331 .

${ }_{220}$ It is difficult to quantify the extent of de facto wilderness, largely due to incomplete data concerning the condition of forest and grazing areas. At one extreme, approximately 562 million acres (about 30 percent of the land surface of the coterminous United States) are occupied by urban areas, crop land, roads, airports, railroads, defense installations, and the like. Daugherty, Major Uses of Land at iii, 2 table 1, 3 table 2, 33 (cited in note 199). Clearly this is not wilderness. At the other extreme, about 187 million acres (about 10 percent of the land surface of the coterminous United States) consists of (a) governmental parks, wildlife refuges, and wilderness areas, and (b) marshes, swamps, sand dunes, rock, deserts, tundra, and similarly "unproductive" land. Id at 3 table 2, 21 app table 1. Most of this land would qualify as de facto wilderness.

The remaining 60 percent of the coterminous United States consists of (a) grazing land (744 million acres, including forest used for grazing), and (b) forest land that is neither used for grazing nor included in a governmental park, refuge, or wilderness area ( 403 million acres). Id at 3,18 . Such grazing land, however, includes "significant areas 
Regardless of which definition is used, however, it is undisputed that the American wilderness is dwindling, as humans continue to erode both its quality and its quantity. ${ }^{221}$ Even the remarkable success of the Wilderness Act in preserving public lands over the last thirty years has merely slowed-not stopped-this chronic decline.

\section{The Rise of the Preservationist Owner}

The preservationist owner is revolutionizing modern wilderness protection. Rejecting the orthodoxy that wilderness preservation is a purely governmental function, the preservationist owner voluntarily elects to maintain the natural condition of her privately owned wilderness land. ${ }^{222}$ She repudiates the nine-

grazed only lightly or sporadically," id at 18 , that would presumably qualify as de facto wilderness. The Council on Environmental Quality reported that only about 3 percent of privately owned rangeland in 1987 and 5 percent of federally owned rangeland in 1990 could be considered in "excellent" condition. 22d CEQ Report at 299 table 56 (cited in note 204). Using this primitive yardstick, I assume conservatively that at least 12 million acres of privately owned rangeland (3 percent of total private acres) and 11 million acres of federally owned rangeland ( 5 percent of total government acres)-a total of 23 million acres-could qualify as de facto wilderness. In addition, approximately one-third of total rangeland was described to be in "good" condition; some of this would also qualify as de facto wilderness. Id.

The $\mathbf{4 0 3}$ million acres of remaining "forest land" includes land "at least 10 percent stocked by trees of any size, including land that formerly had such tree cover and that will be naturally or artificially regenerated." Daugherty, Major Uses of Land at 18. It thus includes large tracts of land that have been subject to recent clearcutting and other timber harvesting activity, and that would not qualify as de facto wilderness. One study demonstrated, for example, that owners holding $\mathbf{4 5}$ percent of total private forest land in Michigan had engaged in "major harvesting" at some time. Department of Agriculture, Resource Bull NC-93, The Private Forest Landowners of Michigan 30 table 25 (1985). Yet, according to the same survey, owners holding 39 percent of the private forest land in the state had never "harvested" timber from their lands, while owners controlling 14 percent had engaged in "minor" harvesting. Id. De facto wilderness would include both forest which has never been logged and forest where the effects of past logging are no longer visible. Estimating conservatively that one-third of this forest land qualifies under this approach, then about 134 million acres of additional forest land is de facto wilderness.

Using these assumptions, at least 344 million acres-about 18.4 percent of the land surface of the coterminous United States-would qualify as de facto wilderness. Given the conservative nature of the assumptions discussed above, the actual figure is probably somewhat higher; thus, a rounded estimate of 20 percent is appropriate.

${ }^{221}$ For example, it has been estimated that publicly owned wilderness is disappearing at the rate of two million acres per year, an area roughly equal in size to Yellowstone National Park. Foreman and Wolke, Big Outside at 19 (cited in note 3). See also Howie Wolke, Wilderness on the Rocks 86-88 (Ludd 1991) (arguing that the Wilderness Act has merely slowed, not stopped, the overall decline of publicly owned wilderness).

${ }_{222}$ Over forty years ago, Aldo Leopold argued for the adoption of a new American "land ethic" that respected the existence of nonhuman species. See generally Aldo Leopold, A Sand County Almanac: With Other Essays on Conservation from Round River 
teenth-century ideology that ownership confers a license to destroy; instead, she envisions ownership as a legal tool to safeguard her wilderness property from degradation. ${ }^{223}$

As the preservation ethic has gained momentum in recent years, private owners have opted to protect millions of acres of American wilderness. For example, The Nature Conservancy, a national environmental organization dedicated to wilderness protection, has acquired property rights in over seven million acres of wild land, an area bigger than Vermont. ${ }^{24}$ Other conservation organizations similarly control large wilderness tracts. ${ }^{225}$ Voluntary wilderness preservation by individual owners, while informal ${ }^{226}$ and difficult to quantify, ${ }^{227}$ is also widespread. An illustrative study conducted by the U.S. Forest Service revealed that title to 10 percent of the private "forest land"228 in Michigan is held by preservationist owners who do

219-20 (Oxford 1966). See also James P. Karp, Aldo Leopold's Land Ethic: Is An Ecological Conscience Evolving in Land Development Law?, 19 Envir L 737 (1989). As Leopold summarized: "A land ethic, then, reflects the existence of an ecological conscience, and this in turn reflects a conviction of individual responsibility for the health of the land." Leopold, Sand County Almanac at 236. The modern preservationist owner-at least partially sharing Leopold's vision-accepts responsibility for the health of her own wilderness land.

${ }^{223}$ Even the Council on Environmental Quality assumes that the American property law system allows private owners to preserve the natural condition of their land. See 15th CEQ Report at 367 (cited in note 6) ("Because private property rights in the United States are relatively secure and extensive, private owners have the ability to protect their lands from over use.").

${ }^{224}$ See Felice Buckvar, Helping Mother Nature: A Job for Volunteers, NY Times Section 14, Westchester Weekly 18, 18 (June 5, 1994); Chris Bolgiano, Private Forests: The Lands Nobody Knows, 96 Am Forests 30, 74 (May/June 1990).

${ }_{225}$ Land trusts, for example, have protected 2.7 million acres, an area twice the size of Delaware. See Land Trust Alliance, 1991-92 National Directory of Conservation Land Trusts v (1991).

${ }^{226}$ Most decisions by private owners to preserve their wilderness land are informal. Suppose $O$, the owner of one thousand acres of sagebrush wilderness, wishes to maintain his land in its undisturbed, natural condition. In the normal course of events, he is unlikely to either memorialize this intention in writing or alter his conduct toward the land in a manner visible to third parties. $O$ might, of course, impose formal preservation restrictions on the land that would bind his successors. See, for example, Swartz v Bianco Family Trust, 874 P2d 430, 432, 435 (Colo Ct App 1993) (noting that owners of onehundred-acre forest tract divided into four lots imposed development restrictions with the "intent to keep the parcel as an area of wilderness"). Alternatively, $O$ might convey a conservation easement in his land to a third party, typically a land trust or other conservation organization. See generally Janet Diehl and Thomas S. Barrett, The Conservation Easement Handbook (Trust for Public Land \& Land Trust Exchange 1988) (discussing the mechanics of conservation easements).

227 For example, the Council on Environmental Quality encountered difficulty in attempting to determine the extent of such private preservation because of "widespread and often small parcel ownership distribution." 15th CEQ Report at 408 (cited in note 6).

${ }^{228}$ For purposes of the survey, "forest land" was described as land "at least 16.7 


\section{not intend to allow timber harvesting. ${ }^{229}$ If the same percentage applies on a national basis, as appears likely, ${ }^{230}$ over thirty-}

percent stocked by forest trees of any size, or formerly having had such tree cover, and not currently developed for nonforest use" and at least one acre in size. Department of Agriculture, Private Forest Landowners of Michigan at 14 (cited in note 220).

223 See Id at 30 table 24 . Although the tone of this study is strongly proharvest, preservationist motivation nonetheless appears. This study indicates that 153,200 owners, controlling 1,832,950 acres of forest land, or about 21 percent of the total 8,798,400 acres of such land, indicated that they would "never" allow timber harvesting on their land in the future. Id. When asked for the primary benefit they derived from their land-in other words, why they would not allow timber harvesting-66,200 owners, controlling 937,100 acres, or about 10.6 percent of total forest land, cited preservationist benefits of "esthetic enjoyment," "nonmotor recreation," or "no important benefit." Id. Owners controlling an additional 222,950 acres (roughly 2 percent of total forest land acreage) cited benefits that might include preservationist motivation such as "farm or domestic use" and "retirement/emergency income." Id.

An additional portion of the study, which examines the reasons why forest land owners had not engaged in harvesting in the past, lends further support to the inference of preservationist motivation. Nonharvesting owners holding 1,177,900 acres, or 13.4 percent of total privately owned Michigan forest land, cited one of the following reasons: "[o]pposed to [timber] harvest," "[r]uin scenery," or "[d]estroy hunting." Id at 30 table 24, 33 table 29.

${ }_{230}$ Numerous studies chronicle the attitudes and characteristics of private forest owners. Gauging the extent of preservationist sentiment from such studies, however, is difficult. These studies are almost uniformly conducted from a nonpreservationist perspective, under which the failure to "harvest" timber is perceived as undesirable waste. Moreover, they typically cover only a small area, which makes extrapolation difficult. Nonetheless, these studies indicate that, depending on the region involved, owners holding between 8 percent and 32 percent of total private forest acreage intend never to allow logging.

For example, a study of Minnesota forest owners demonstrated that owners controlling 898,600 acres of such land (about 18 percent of the total 5,100,350 acres of private forest land in the state) responded that they would never allow timber harvesting on their land. Department of Agriculture, Resource Bull NC-95, The Private Forest Landowners of Minnesota-1982 30 table 21 (1982). When asked why they had not engaged in timber harvesting in the past, once again, owners holding roughly 18 percent of total private forest land (899,750 acres) cited preservationist reasons: "nonmotor recreation" (owners of 322,100 acres); "esthetic enjoyment" (owners of 414,600 acres); and "no important benefit" (owners of 163,050 acres). Id at 31 table 22.

Similarly, a survey of private forest owners in Windham County, Connecticut found that owners controlling 8 percent of privately owned "woodland" $(2,163$ of the total 26,436 woodland acres in the county) intended never to allow timber harvesting, while owners holding 25 percent (6,562 acres) were unsure whether they would allow logging. Thomas Holmes and Joseph Diamond, An Analysis of Non-Industrial Private Woodland Owners' Attitudes Toward Timber Harvesting and Forest Land Use in Windham County, Connecticut, 197911 table 14 (Connecticut 1980). Moreover, owners holding 24.8 percent of total private woodland (6,343 acres) cited a preservationist "primary reason" for owning their land: "aesthetic enjoyment" (owners of 4,180 acres); and "personal recreation" (owners of 2,163 acres). Id at 8 table 10.

See also Samuel M. Brock, et al, A Focus on West Virginia's Retired Forest Landowners 10 (West Virginia 1985) (Circular 135) (reporting that owners holding 18 percent of private West Virginia forest land only use the land for "recreation or esthetic enjoyment"); Ervin G. Schuster, Attitudes \& Activities of Private Forest Landowners in Western Mon- 
three million acres of forest wilderness ${ }^{231}$-an area larger than Arkansas-are shielded by preservationist owners from destruction. It is reasonable to assume that many individual owners controlling wild prairie, desert, rangeland, and wetland parcels also share the preservation ethic. ${ }^{232}$

Private preservation is a vital counterpart to the Wilderness Act. Existing public wilderness areas do not encompass many of the terrestrial and wetland ecosystem categories found in the United States. ${ }^{233}$ In large part, the Wilderness Act protects federal lands which were the least desirable for exploitative use and thus escaped nineteenth-century distribution to private owners. $^{234}$ These "lands that nobody wanted"235 often lack ecological diversity. The preservation of private wilderness land thus offers the best opportunity to protect ecosystems that are

tana 55-56 \& table 19 (Dept of Agriculture 1978) (noting that 16 percent of private forest owners in western Montana "never" intend to "harvest" their lands, while 31 percent offer preservationist reasons for not harvesting in the past); Robert E. Jones and James S. Paxton, The 296 Million Acre Myth, 83 Am Forests 6, 8 (Nov 1977) (observing that in a poll of forest owners in 14 northeastern states, "fewer than 10 percent expressed an interest in wood or fiber production"); Brian J. Turner, James C. Finley, and Neal P. Kingsley, How Reliable Are Woodland Owners' Intentions?, J Forestry 498, 499 table 2 (Aug 1977) (noting that in a survey of Delaware woodland owners, respondents owning 32 percent of the total land in the sample indicated they would never allow logging).

${ }^{231}$ The U.S. Forest Service classifies 346.8 million acres netionally (excluding Alaska) as privately owned "forest land." See US Forest Service, Resource Bull WO-1, The Private Forest-Land Owners of the United States 29 table 1 (1982). I assume here that the estimated acreage controlled by preservationist owners qualifies at least as de facto wilderness in most instances on the reasoning that these owners-those most familiar with the land involved-believe that their property merits preservation in its current condition.

${ }^{232}$ For illustrative case studies of private land preservation efforts in a variety of settings, see 15th CEQ Report at 363-429 (cited in note 6). See also Karp, 19 Envir L at 762 63 (cited in note 222) (discussing the increasing acceptance of Leopold's land ethic by private citizens).

${ }^{233}$ See David W. Crumpacker, et al, A Preliminary Assessment of the Status of Major Terrestrial and Wetland Ecosystems on Federal and Indian Lands in the United States, 2 Conservation Biology 103, 111-14 (1988). Crumpacker observes:

Nine of the 135 major terrestrial and wetland ecosystem types in the United States have no representation in ... U.S. federal and Indian lands. Eleven others have relatively little representation.... An additional 13 types have relatively little federal representation but are generally more common in the United States or less affected by land use conversions. Thus at least 24 percent (33 out of 135) of the major terrestrial and wetland ecosystems in the United States should be given special consideration....

Id at 111. Crumpacker also notes that "[t]wo types of land will tend to offer some degree of long-term protection to ecosystems: 1) public land and 2) private land that is designated for conservation ...." Id at 105.

${ }^{234}$ See Wolke, Wilderness on the Rocks at 85-90 (cited in note 221).

235 15th CEQ Report at 364 (cited in note 6). 
underrepresented - or not represented at all-in public wilderness areas. ${ }^{236}$

In addition, federal budgetary constraints threaten the expansion of public wilderness protection; ${ }^{237}$ private preservation, in contrast, requires no governmental funding. As the Council on Environmental Quality predicted: "the policies of recent decades, of primary reliance upon the public sector to protect and preserve the country's natural resources, will no longer be sufficient to the task. We will have to rely heavily upon private landowners and organizations to play a ... greater role in protecting these resources."238

\section{The Antiwilderness Bias in Contemporary Property Law}

1. Beneath a benign facade.

The rhetorical tone of contemporary opinions concerning wilderness land is typically prowilderness, almost diametrically opposed to the tenor of parallel nineteenth-century decisions. This reversal is epitomized by the Supreme Court's 1967 opinion in Udall v Federal Power Commission, where the Court finally acknowledged "the public interest in preserving... wilderness areas. ${ }^{239}$

In the wake of Udall, courts have extolled the scenic, ${ }^{240}$ rec-

${ }^{235}$ See, for example, Farrier, 19 Harv Envir L Rev at 311 (cited in note 8) ("Although wetlands provide a significant portion of both ecosystem and species biodiversity, it has been estimated that about seventy-five percent of wetlands in the lower forty-eight states are located on private property.").

${ }_{207}$ See 15th CEQ Report at 364 (cited in note 6).

223 Id. Moreover, "the preservation of the public domain lands, while important, will likely not be sufficient to preserve considerable amounts of America's flora and fauna and wealth of biological diversity over time; the contribution of private land ownership to the protection and preservation of natural resources becomes critical." Id at 363-64.

239387 US 428, 450 (1967). Unsurprisingly, Justice Douglas-an avid environmentalist-wrote the majority opinion. Five years later, in Sierra Club v Morton, although praising the undeveloped Mineral King Valley as a "quasi-wilderness area largely uncluttered by the products of civilization," the Court held that the Sierra Club lacked standing to challenge development of a ski resort complex. 405 US 727, 728 (1972). Justice Douglas responded with an impassioned dissent, perhaps the strongest judicial endorsement of wilderness preservation on record. Id at 741-52 (Douglas dissenting).

${ }^{240}$ See, for example, Oregon Natural Resources Council, Inc. v United States Forest Serv, 659 F Supp 1441, 1442 (D Or 1987):

The centerpiece of the area involved in this case is a river gorge of heart-stopping magnificence. It lies at the bottom of a steep slope of old growth virgin timber; brooding, and presiding over this area is majestic Mt. Jefferson, whose name has been given to the nearby wilderness area. Its beauty is as deep as the determination of the plaintiffs, who seek to protect it.... 
reational, ${ }^{241}$ spiritual, ${ }^{242}$ and ecological ${ }^{243}$ values of wilderness land. Judicial disparagement of wilderness is now the exception rather than the rule. ${ }^{244}$

See also State $v$ Fin \& Feather Club, 316 A2d 351, 359 (Me 1974) ("The responsibility ... of this Court is great to protect the vision of Percival P. Baxter who realized the precious and tenuous existence of our State's wilderness. . . The wild beauty of Maine's forests is part of every Maine citizen's heritage."); Just $v$ Marinette County, 56 Wis 2d 7, 201 NW2d 761, 768 (1972) ("Swamps and wetlands . . . now, even to the uninitiated, possess their own beauty in nature.").

${ }^{241}$ See, for example, Sierra Club v United States Department of Transportation, $664 \mathrm{~F}$ Supp 1324, 1331 (N D Cal 1987) (lamenting that "[t]he unspoiled wilderness through which hikers now walk will be interrupted by the freeway, and the cuts and fills will be plainly visible").

${ }_{242}$ See, for example, Cleveland Electric Illuminating Co. v Scapell, 41 Ohio Misc 107, 324 NE2d 610, 614 (Ct CP 1974):

Physical progress must be respectful and sensitive to life and to the rapidly diminishing area still open and available for wilderness parks and recreation.... How do we accommodate the good life, its superabundance of material goods and services with the soul of men which has very significant, almost insatiable [ ] needs which only Nature can satisfy? . . [The plaintiffs] sense a mandate to preserve, to conserve; they envision an exodus of tired, nature starved people streaming into the park to enjoy the wonderful mysteries of nature in an uncluttered surrounding. The court feels that to place the ecological issues in proper perspective we must conceive not in terms of decades or lifetimes but in terms of ages....

See also Davies $v$ Meyer, $541 \mathrm{SW} 2 \mathrm{~d}$ 827, 829 (Tex 1976) ("Certainly inspiration and a spirit or [sic] renewal may be captured by experiences with nature and the wilderness . . ..7).

${ }^{243}$ See, for example, Bob Marshall Alliance $v$ Watt, 685 F Supp 1514, 1515 (D Mont 1986):

Along with the wilderness complex it borders, the Deep Creek Area may well support a large portion of the entire grizzly population of the contiguous 48 states.

...

The unique geological and ecological attributes of the Deep Creek Area account for the area's receiving a perfect wilderness attribute rating in the Forest Service's Roadless Area Review and Evaluation ....

See also Marks $v$ Whitney, 6 Cal 3d 251, 98 Cal Rptr 790, 796 (1971):

There is a growing public recognition that one of the most important public uses of the tidelands ... is the preservation of those lands in their natural state, so that they may serve as ecological units for scientific study, as open space, and as environments which provide food and habitat for birds and marine life....

See also Just, 201 NW2d at 768:

Swamps and wetlands were once considered wasteland, undesirable, and not picturesque. But as the people became more sophisticated, an appreciation was acquired that swamps and wetlands serve a vital role in nature, are part of the balance of nature and are essential to the purity of the water in our lakes and streams. 
Yet despite this reassuring rhetoric, the content of modern property law still embodies the nineteenth-century antiwilderness bias. Modern courts have lost sight of the historical roots of our property law system. Although espousing prowilderness sentiments in good faith, the judiciary blindly applies most of the antiwilderness doctrines of the past. Thus, individual disputes tend to be resolved in favor of wilderness exploitation. More importantly, the historic body of antiwilderness opinions continues to exist, setting public norms for private conduct outside of the litigation arena. ${ }^{245}$ The accumulated precedents of two centuries constitute a virtual common law of wilderness destruction that threatens the existence of privately owned wilderness sanctuaries. ${ }^{246}$

\section{Land-use disputes between co-owners: waste.}

The modern law of waste remains staunchly hostile to wilderness, reflecting its nineteenth-century reconfiguration toward placing such land in productive use. Whether informally consulted as a guide to conduct or judicially applied to resolve a landuse dispute between parties holding successive or concurrent interests in the same parcel, the doctrine tends to favor the exploiter over the preserver. Therefore, although the number of

ple, Weber Basin Water Conservancy District v Gailey, 8 Utah 2d 55, 328 P2d 175, 177 (1958) (noting that Utah was originally "a dry and arid desert region with only sparse vegetation" whose settlers should "take justifiable pride in having their achievements referred to as causing the once unpromising desert wilderness to 'blossom as a rose").

245 For useful summaries of the view that one function of law is the "coordination of human interaction" outside of the dispute resolution context, see Steven D. Smith, Reductionism in Legal Thought, 91 Colum L Rev 68, $72-73$ (1991); Susan Bandes, The Idea of a Case, 42 Stan L Rev 227, 299 (1990) (discussing the "public norm creation" function of law).

${ }^{246}$ Reported decisions involving an avowed preservationist owner of wilderness land are rare because the private preservation movement is a comparatively recent phenomenon. See, for example, Channer v Tomlinson, 1993 Neb App LEXIS 33, *6-7 (involving preservationist owner who sought to establish wildlife habitat program on unfenced land covered with "natural growth," but was barred by the free-range doctrine from recovering for the damage caused by his neighbor's trespassing cattle). The past interaction between the property law system and governmentally owned preserves, however, is ominous. Although they are somewhat insulated from the direct effects of property law by sovereign immunity and related doctrines, public preserves have suffered as a result of the antiwilderness bias. See, for example, United States $v$ Hato Rey Building Co., 660 F Supp 1340 , 1347-48 (D PR 1987) (allowing occupants who cleared vegetation and built structures on forty acres of national forest land to recover compensation as good faith improvers); Pennsylvania Game Commission v Ulrich, 129 Pa Commw 376, 565 A2d 859, 862 (1989) (holding that commonwealth was not a bona fide purchaser of thirty-eight forest acres for inclusion in the state forest system because a prior claimant held possession of the property by "hunting and collecting firewood"). 
cases implicating waste issues has diminished, the doctrine nevertheless imperils voluntary efforts of wilderness owners to preserve natural lands.

First, the waste doctrine encourages the destruction of wilderness lands in pursuit of agricultural expansion. The nineteenth-century "good husbandry" standard, permitting the occupant to clear wilderness land for cultivation, remains virtually intact, ${ }^{247}$ and the practice of converting wilderness into farm land is still widespread. ${ }^{248}$ Thus, suppose $A$ holds a tenancy for years in a tract consisting of one hundred acres of farm land and two hundred acres of wild wetlands, with a reversion in $B ; B$ dies, devising his reversion interest to $C$, an avid environmentalist. $A$ now proposes to clear the two hundred acre tract for agricultural use; this will enhance its market value, but irreparably devastate its wilderness condition. $C$ objects. Prudent agricultural development is the lone criterion considered under the good husbandry standard. Measured against this yardstick, $A$ 's proposed land clearing is an improvement, not an impairment. $C$ 's environmental concerns are irrelevant.

Second, the doctrine facilitates the conversion of wild forest land unsuited for farming into commercial tree plantations, regardless of the wishes of the preservationist interest holder. Courts still cling to the nineteenth-century rule that allows intensive logging on an entire parcel, over the objections of other interest holders, if the previous owner sporadically logged even

247 See, for example, In re Tremblay, 43 Bankr 221, 223 (Bankr D Vt 1984) (following good husbandry standard); Campion v McLeod, 108 Ga App 261, 132 SE2d 848, 848-49 (1963) (same); Bridgers v Bridgers, 56 NC App 617, 289 SE2d 921, 923 (1982) (same); Merriman v Moore, 600 SW2d 720, 722 (Tenn 1980) (same). See also Powell, 5 Real Property II 640[1] at 56-16 to 56-17 (cited in note 23) (discussing the predominance of the good husbandry standard). But see Knowles $v$ Moore, 622 SW2d 803, 804-05 (Mo Ct App 1981) (holding that tenant's conversion of 400 acres of "true prairie" into cropland was waste because "the land was not suitable for tillage and the planting of grain crops").

${ }^{248}$ See, for example, Manville $v$ Gronniger, 182 Kan 572, 322 P2d 789, 791-92 (1958) (involving title claimant who cleared brush from part of 227 acres for cultivation); Knowles, 622 SW2d at 804 (involving tenant who converted 400 acres of "true prairie" covered with native grasses into cultivated cropland); Hitchcock $v$ Ledyard, $48 \mathrm{~J} \mathrm{Okla} \mathrm{Bar}$ Assoc 2525, 2526 (Okla Ct App 1977) (involving title claimant who cleared part of 600acre riverside parcel); Cuka v Jamesville Hutterian Mutual Society, 294 NW2d 419, 421 (SD 1980) (involving title claimant who cleared part of 13-acre wooded tract). Between 1945 and 1980 , for example, approximately 15 million acres of forested wetland areas were placed in agricultural use. See 16th CEQ Report at 97 (cited in note 2). See also J. Greg Jones and Richard P. Thompson, Characteristics, Attitudes, and Objectives of Nonindustrial Private Forest Owners in Eastern Oklahoma 9 (Oklahoma State 1981) (reporting that 18 percent of privately owned forest land in eastern Oklahoma is controlled by owners who intend to clear it for pasture or crop land). 
part of the property. ${ }^{249}$ One Tennessee decision, for example, allowed a life tenant to engage in commercial cutting on 650 acres of "hill hardwood timber land," whose only economic use was as timberland, where the prior owner had cut timber on portions of the land only occasionally over a seventy-year period. ${ }^{250}$ Similarly, even absent any evidence of historical cutting, most jurisdictions reason that timber is essentially a crop and thus apply the good husbandry standard by allowing limited timber cutting whenever such cutting enhances the market value of forest land. ${ }^{251}$ Thus, a Georgia court allowed a life tenant to cut mature pine trees from a 350-acre tract "covered with pine forest" which was "fit for little else than the growth and sale of marketable pine timber." ${ }^{252}$ The court concluded that good husbandry required removal of the mature timber in order to protect "the new crop" of trees, and noted the life tenant's ironic plea that "if the trees are not cut this would constitute a waste of the timberland resources." ${ }^{253}$ Other courts permit the cutting and sale of timber from wilderness land on the rationale that such "thinning" is an approved forestry practice. ${ }^{254}$

Accordingly, suppose $D$ and $E$ are joint tenants, each owning a one-half undivided interest in five hundred acres of forest wilderness never subjected to logging. If $D$ proposes to convert the land into a tree plantation, modern waste law will not counte-

249 See, for example, Robinson $v$ Robinson, 283 Ala 257, 215 S2d 585, 590-91 (1967) (recognizing rule); First National Bank of Mobile $v$ Wefel, $252 \mathrm{Ala} 212,40 \mathrm{~S} 2 \mathrm{~d} 434,437-38$ (1949) (allowing commercial cutting on 10,559 acres where settlor of trust had done so during his lifetime); Durrence $v$ Durrence, 239 Ga 705, 238 SE2d 377, 378 (1977) (allowing cutting of 684 acres by life tenant where testator had done so during his lifetime); Temple $v$ Carter, 3 NC App 515, 165 SE2d 541, 543-44 (1969) (recognizing rule); Pedro v January, 261 Or 582, 494 P2d 868, 875 (1972) (recognizing rule); Merriman, 600 SW2d at 723, 725 (allowing commercial cutting by life tenant on 650 acres of "hill hardwood timber land" based on prior owner's conduct).

${ }^{250}$ Merriman, 600 SW2d at 723.

251 See, for example, Sutton v Bennett, $215 \mathrm{Ga} 379$, 110 SE2d 650, 650 (1959) (allowing a life tenant to cut pine trees on "woodland" for sale as pulpwood because "thinning the pine timber" was "in accordance with approved forestry practices"); Thompson $v$ Thompson, 206 Tenn 202, 332 SW2d 221, 227 (1960) (allowing a life tenant to cut and sell mature cedar and oak trees because this would benefit the property by fostering the growth of younger trees). See also Sauls $v$ Crosby, 258 S2d 326, 327 (Fla Dist Ct App 1972) (recognizing rule); Pedro, 494 P2d at 875 (same); Seattle-First National Bank v Brommers, 89 Wash 2d 190, 570 P2d 1035, 1042 (1977) (same). Compare Threatt $v$ Rushing, 361 S2d 329, 331 (Miss 1978) (finding waste where life tenant cut mature trees that constituted about 10 percent of the total board feet on the parcel because the cutting was not "good husbandry" but a "commercial operation . . . for profit").

${ }_{252}$ Brogdon v McMillan, 116 Ga App 34, 156 SE2d 828, 829 (1967).

253 Id.

${ }^{254}$ See, for example, Sutton, 110 SE2d at 650. 
nance $E$ 's preservationist objection. ${ }^{255} D$ 's activity will cause ecological damage that is subtle but real. ${ }^{256}$ For example, spraying herbicide to remove brush and noncommercial trees, a common tree-farm technique, drastically reduces forest biodiversity. ${ }^{257}$ Moreover, even selective timbering poses a variety of environmental risks ranging from soil erosion to habitat destruction..$^{258}$

The waste doctrine thus tends to encourage wilderness exploitation. In this manner, modern waste law impairs the ability of preservationist interest holders to protect their wilderness lands.

\section{Title disputes between competing claimants.}

The antiwilderness bias pervades basic title doctrines. As their nineteenth-century ancestors exalted the user over the idler in resolving wilderness title disputes, modern courts effectively prefer the exploiter to the preserver. If $F$, an ardent preservationist, and $G$, an industrious logger, both claim title to the same forest parcel today, the law tends to vest title in $G$.

${ }^{255} E$ could, of course, easily force partition of the property in most states. See generally Richard R. Powell, 4A Powell on Real Property III 607, 618[2] at 50-43 to 50-61, 5120 to 51-21 (Matthew Bender 1995) (describing the right to partition between concurrent owners). Yet partition may prove an unsatisfactory remedy. A court might force the sale of the land to third parties, probably nonpreservationist owners, rather than physically dividing the property between $D$ and $E$. Moreover, even assuming that partition in kind is possible, $E$ may not be able to obtain a partition judgment quickly enough to forestall $D$ 's conduct. See, for example, St. Regis Paper Co. v Kerlin, 476 S2d 64, 65 (Ala 1985) (noting that while appeal was pending in title dispute, the plaintiff's lessee "cut down all of the trees on the property").

256 The transformation of wild forest to tree plantation converts a complex natural ecosystem supporting many plant and animal species into a commercial enterprise typically managed to encourage the production of one tree species. This transformation has a broad range of environmental effects. See Mitch Lansky, Beyond the Beauty Strip: Saving What's Left of Our Forests 109-14 (Tilbury House 1992) (discussing environmental effects of tree plantations); see also Goudie, Human Impact at 130-36 (cited in note 205) (analyzing soil erosion caused by deforestation).

${ }^{257}$ Department of Agriculture, Agricultural Handbook No 534, Predators of the Gypsy Moth 68 (US GPO 1978) (noting that use of such herbicide sprays in forests "often drastically reduce[s] both vertebrate species diversity and the total number of birds and small mammals in the area").

${ }^{258}$ See Goudie, Human Impact at 130-36 (cited in note 205) (discussing the effect of deforestation on soil erosion); Lansky, Beyond the Beauty Strip at 245-47 (cited in note 256) (summarizing impact of logging on wildlife habitat); George A. Gould, Agriculture, Nonpoint Source Pollution, and Federal Law, 23 UC Davis L Rev 461, 466-68 (1990) (discussing manner in which sediments eroded by logging activity may affect aquatic life). 
a. Adverse possession. Just as in the nineteenth century, it is easier to adversely possess wilderness land than nonwilderness land. Almost all jurisdictions still use a reduced adverse-possession threshold for wilderness. ${ }^{259}$ This standard is based not on what reasonable notice requires, but rather on what economic use the existing condition of the land allows. As a result, adverse possession of wilderness may be founded on occasional activities that leave behind no visible traces. ${ }^{260}$ Applying this standard, twentieth-century courts have transferred title to adverse possessors based on such limited activities as harvesting natural hay, ${ }^{261}$ seasonal stock grazing, ${ }^{262}$ and cutting small amounts of timber. ${ }^{263}$ In a modern New York case, for example, the owner of 260 acres of wild forest land lost title to an adverse claimant whose only activities were tree cutting, occasional hunting, and paying taxes on the land. ${ }^{264}$

Modern adverse possession law threatens environmental damage. It encourages the adverse claimant to place wilderness land in at least minimal economic use-such as grazing or logging-in order to acquire title. It also encourages the true owner to do the same-so as to negate the exclusive possession element of adverse possession, and thus retain title-by undertaking similar exploitative activities suited to the primitive condition of the property. ${ }^{265}$ Such timber cutting or grazing may in turn

${ }^{259}$ In some states, the rule is explicit: an adverse claimant to lands that are "wild," "outlying and uncultivated," not suited for "any useful permanent improvement," or "undeveloped" need only perform the activities suited to the land in its natural condition. See Sprankling, 79 Cornell L Rev at 828-29 (cited in note 9). In most states, though, the rule is implicit: the adverse claimant must use the land in the same manner a reasonable owner would, taking into account its nature, character and location. Id at 829.

${ }_{200}$ See, for example, Klingel v Kehrer, 81 III App 3d 431, 401 NE2d 560, 563, 566 (1980) (allowing adverse possession of small tract of undeveloped riverside land based on nut gathering and occasional cutting of pecan trees, even though record owner testified that he had never seen any evidence of such cutting).

${ }_{251}$ Weiss $v$ Meyer, 208 Neb 429, 303 NW2d 765, 769-70 (1981) (allowing adverse possession of grassland strip based on harvesting of natural hay); Thompson $v$ Hayslip, 74 Ohio App 3d 829, 600 NE2d 756, 760 (1991) (allowing adverse possession based on hay cutting).

${ }_{252}$ See, for example, Quarles v Arcega, 114 NM 502, 841 P2d 550, 561 (NM Ct App 1992) (allowing adverse possession of sixty-three acres of rangeland based on seasonal grazing); Cooper v Carter Oil Co., 7 Utah 2d 9, 316 P2d 320, 323-24 (1957) (allowing adverse possession of rangeland based on three weeks of grazing each season).

${ }^{263}$ See, for example, Sheppard v T.R. Miller Mill Co., 332 S2d 374, 375-76 (Ala 1976) (permitting adverse possession of forty acres of swamp and timberland in part because of limited tree cutting); Sleboda $v$ Heirs at Law of Harris, 508 A2d 652, 657-58 (RI 1986) (allowing adverse possession of fifteen acres of woods based on gathering firewood and cutting trees on visits).

${ }_{2 s}$ Goff $v$ Shultis, 26 NY2d 240, 309 NYS2d 329, 334 (1970).

${ }_{265}$ See, for example, Raftopoulos v Monger, 656 P2d 1308, 1311-12 (Colo 1983) (en 
cause soil erosion, sediment pollution in streams, and injury to undergrowth, ${ }^{266}$ ultimately degrading wilderness quality.

More importantly, adverse possession tends to transfer wilderness land from the preservationist owner to the exploitative claimant. ${ }^{267}$ Once vested with title, the successful adverse claimant is free to clear the property, thereby destroying its wilderness value. ${ }^{268}$

b. Possession and the bona fide purchaser. The modern bona fide-purchaser standard still pivots on the nature and character of the land. Admittedly, courts frequently recite that constructive notice requires possession that is actual, open, notorious, and so forth-language that echoes the adverse possession standard. ${ }^{269}$ Despite this rhetoric, however, most authorities acknowledge that the required possession is defined by economic activities suited to the nature and condition of the land; ${ }^{270}$ thus,

banc) (holding owner's use of 120-acre parcel of rangeland for grazing three to fifteen days each year precluded adverse possession); Hutson $v$ Rush Creek Land \& Livestock Co., 206 Neb 658, 294 NW2d 374, 376 (1980) (holding owner's use of wild land for hunting precluded adverse possession); Rickel v Manning, 369 SW2d 655, 657-59 (Tex Civ App 1963) (holding owner's cutting of timber from 20 acres of "rough, mountainous terrain" two or three times each year precluded adverse possession). See also Sprankling, 79 Cornell $\mathrm{L}$ Rev at 837-38 nn 91-95, 852-53 nn 171-73 (cited in note 9).

${ }^{266}$ See Richard Whitman, Clean Water or Multiple Use? Best Management Practices for Water Quality Control in the National Forests, 16 Ecol L Q 909, 917-19 (1989) (noting that timbering methods generally involve the use of heavy equipment to transport logs, resulting in damage to undergrowth, soil erosion and sedimentary pollution in watercourses); 16th CEQ Report at 49 (cited in note 2) (describing similar environmental effects of grazing). See also Lansky, Beyond the Beauty Strip at 109-14 (cited in note 256) (describing effects of timber harvesting); Goudie, Human Impact at 130-36 (cited in note 205) (describing timber harvesting's effect on soil).

${ }^{267}$ See text accompanying notes 114-18.

268 Undoubtedly, many owners value wilderness land simply as a unit of commerce. See, for example, Department of Agriculture, Private Forest Landowners of Minnesota at 30 table 21 (cited in note 230) (reporting results of study of Minnesota forest owners in which owners holding 2,160,150 acres, or 42 percent, of privately owned forest land indicated an intention to harvest timber on the land within 10 years).

${ }^{269}$ As the Wisconsin Supreme Court observed: "the requirements as to the type of possession that will constitute [ ] notice [to a later claimant] are practically identical with the requirements of the type of possession necessary to constitute adverse possession." Miller $v$ Green, 264 Wis 159, 58 NW2d 704, 707 (1953).

${ }^{270}$ See, for example, Baldwin County Federal Savings Bank $v$ Central Bank of the South, $585 \mathrm{~S} 2 \mathrm{~d} 1279,1282$ (Ala 1991) (observing, in case involving undeveloped land, that to establish possession the owner "need only make use of the property in a manner that is consistent with its nature"). This principle is also reflected in standard treatises. See, for example, David A. Thomas, ed, 11 Thompson on Real Property \$ 92.15(c)(1) at 179 (Michie 1994) (commenting that the acts necessary to constitute possession sufficient to afford constructive notice to later purchasers require consideration of the "particular facts and circumstances," including "the physical characteristics and location of the property"); 92 
relatively unobtrusive activities, such as occasional pasturing or timber cutting, could constitute possession of wilderness land sufficient to provide constructive notice. ${ }^{271}$ In one modern decision, the buyer of forty thousand acres of Arizona rangeland was denied bona fide-purchaser protection due to the presence of grazing cattle on part of the land; his title was deemed subject to the unrecorded interest of the cattle owner. ${ }^{272}$ Like its nineteenth-century ancestor, then, the modern bona fide-purchaser doctrine ensures productive land use, regardless of whether such use realistically affords notice to later claimants. ${ }^{273}$

The modern formulation of the rule may damage wilderness land in two ways. First, the holder of a nonrecordable interest in such property might despoil it to insulate his title against thirdparty attack. Suppose owner $H$ enters into an installment land contract to sell a one-hundred-acre forest tract to $J$, giving $J$ the immediate right of possession but deferring the transfer of title until $J$ tenders all required payments. Normally, a vendee such as $J$ would wish to protect his equitable interest in the land by

CJS Vendor and Purchaser \$ 348 at 279 (1955) (observing that the sufficiency of possessory acts "depend[s] on the circumstances of the particular case, including the nature of the land, and the uses to which it is adapted"); $77 \mathrm{Am}$ Jur 2d Vendor and Purchaser $\$ 675$ at 782 (1975) (noting that sufficient possession may be "shown by any use of the land that indicates an intention to appropriate it for the benefit of the possessor; such use may be any to which the land is adapted"). Compare Casner, ed, 4 American Law of Property \$ 17.15 at 583-84 (cited in note 110) (commenting that in a number of jurisdictions human occupancy is not necessary for possession).

${ }_{271}$ See, for example, Casner, ed, 4 American Law of Property $\$ 17.15$ at 584 (cited in note 110) (suggesting that use of land for pasture or cutting of timber would suffice). But see Ortiz $v$ Jacquez, 77 NM 155, 420 P2d 305, 308 (1966) (holding that grazing sheep four weeks each year on approximately five hundred acres of unfenced rangeland did not afford notice). A higher standard applies, however, when the property involved is farmland. See, for example, Flaspohler v Hoffman, 652 SW2d 703, 709 (Mo Ct App 1983) (holding that cultivation of wheat on portion of large farmland tract was insufficient possession to afford constructive notice).

${ }_{272}$ Phoenix Title \& Trust Co. v Smith, 101 Ariz 101, 416 P2d 425, 432 (1966) ("Plaintiffs had constructive notice.... Defendants were using the lands for grazing purposes at the time plaintiffs made their purchase."). See also Horn $v$ Lawyers Title Insurance Corp, 89 NM 709, 557 P2d 206, 207 (1976) (buyer of 116,000-acre New Mexico tract denied bona fide-purchaser protection because his agent, who inspected the land by airplane before the purchase, failed to notice the grazing, seasonal cultivation, and weekend visiting activities of prior claimant to part of the land).

273 Recent decisions applying the bona fide-purchaser doctrine to wilderness land are scant, both because the frequency of recording has increased and the amount of wilderness has decreased. Moreover, the increased use of "no trespassing" signs has also minimized reliance on intermittent acts as constructive notice. See, for example, Natural Resources, Inc. $v$ Wineberg, $349 \mathrm{~F} 2 \mathrm{~d} 685,690$ (9th Cir 1965) (involving buyer of 880 acres of timberland under unrecorded deed, whose printed signs on the property, together with a "no trespass" warning, were held to afford constructive notice to a later buyer). 
recording the contract. ${ }^{274}$ Like many vendors, however, $H$ might prefer to avoid recordation in order to minimize title difficulties in the event $J$ defaults. ${ }^{275}$ Accordingly, $H$ could either expressly bar recordation through a negotiated clause or effectively prevent recordation by, for example, ensuring that his signature on the contract was not acknowledged before a notary public. ${ }^{276}$ Under these circumstances, $J$ might be motivated to cut timber or even clear the land, in order to generate constructive notice and thus shield his interest against later claims. ${ }^{277}$ Vendees under oral contracts, lessees under unacknowledged leases, and holders of other similar unrecordable interests would be similarly motivated.

Second, the doctrine tends to vest title in the exploiter rather than the preserver. A recent Pennsylvania decision resolving a title dispute over thirty-eight acres of forested mountain land illustrates the point. ${ }^{278}$ The defendant, whose chain of title was founded on an unrecorded deed, periodically used the property for "hunting and collecting firewood." The plaintiff, the Commonwealth of Pennsylvania, subsequently purchased the land from the record owner as an addition to its state forest system and, after learning about the defendant's interest, brought a quiet title action claiming protection as a bona fide purchaser. In accordance with the majority standard, however, the relatively minor

274 See Harry D. Miller and Marvin B. Starr, 1 Current Law of California Real Estate $\S 2: 48$ at 694 (Bancroft-Whitney $2 d$ ed 1989) (noting that although in the normal sales transaction-outside of the wilderness context-the vendee's possession "probably gives notice of his interest in the property to third parties, the contract should be recorded to avoid potential conflict with subsequent purchasers or encumbrancers who claim they did not have adequate notice").

275 If the defaulting vendee's equitable interest is not reflected in a recorded instrument, the vendor has clear record title; she can freely sell, encumber, or otherwise transfer rights and interests in the land to third parties who will qualify for protection as bona fide purchasers or encumbrancers. If, on the other hand, the defaulting vendee's equitable interest is recorded in some manner, the vendor will be required to clear her title to the land, either through litigation or a voluntary settlement with the vendee.

${ }^{276}$ See Miller and Starr, 1 California Real Estate § 2:48 at 695-96 (cited in note 274) (discussing ability of vendor to prevent recordation of installment land contract).

${ }^{277}$ See, for example, In re Probasco, 839 F2d 1352, 1353, 1355-56 (9th Cir 1988) (claimant to seventy-six acres of "undeveloped land" provided constructive notice by constructing roads and fencing property); Story $v$ Grayson, 208 Ark 1029, 185 SW2d 287, 288 (1945) (acknowledging that clearing and cultivating land would provide constructive notice); Hoggarth $v$ Somsen, 496 NW2d 35, 41 (ND 1993) (ordering new trial to consider whether cultivation afforded constructive notice); Miller, $58 \mathrm{NW} 2 \mathrm{~d}$ at 707 (claimant to sixty-three-acre parcel provided constructive notice by plowing two acres).

${ }_{278}$ Pennsylvania Game Commission v Ulrich, $129 \mathrm{~Pa}$ Commw 376, 565 A2d 859 (1989).

279 Id at 862. 
activities of the defendant were held sufficient, given the nature and character of the land, to constitute constructive notice of his claim. The defendant's track record of economic use prevailed over the Commonwealth's preservationist motivation. Now holding unchallenged fee simple absolute title, the defendant is free to devastate the property.

c. Good faith improver. Today almost all states ignore the English common law restrictions on the good faith-improver doctrine. ${ }^{280}$ Betterment statutes in most states enlarge the rights of the good faith improver, ${ }^{281}$ one common provision gives the true owner the option of either selling the property to the improver or paying for the value of the improvements. ${ }^{282}$ Moreover, the twentieth century has seen the revival of the judicial movement toward allowing the mistaken improver to maintain an independent cause of action, regardless of whether a betterment statute is in place. ${ }^{283}$ Courts in about one-third of the states have now followed this course. ${ }^{284}$

Because modern American courts still consider the mistaken destruction of wilderness to be a compensable "improvement", the expanded good faith-improver doctrine rewards despoliation. One strand of decisions compensates the good faith improver who clears wilderness land for cultivation. ${ }^{285}$ An illustrative Ten-

2*5 Alaska, Arizona, Montana, New Jersey, New York, Oregon and Tennessee have all codified the English rule. Statutes in most states, however, provide enhanced protection for the good faith improver. See Dickinson, 64 NC L Rev at $42-43$ \& nn 29-30 (cited in note 142).

${ }^{2 \times 1}$ Id at $42 \mathrm{n} 28$ (citing betterment statutes in forty-two jurisdictions).

$2 \times 2$ Id at $44 \& \mathrm{n} 45$.

${ }_{2 \times 3}$ See, for example, George E. Palmer, 2 The Law of Restitution $\S 10.9$ at $444-45$ (Little, Brown 1978) ("In recent years a substantial body of authority has developed which supports affirmative relief in favor of the mistaken improver, without regard to whether the state has a betterment statute.").

234 See, for example, Pull v Barnes, 142 Colo 272, 350 P2d 828, 829-30 (1960); Voss $v$ Forgue, 84 S2d 563, 564 (Fla 1956); Smith v Long, 76 Idaho 265, 281 P2d 483, 485 (1955); Duncan v Akers, 147 Ind App 511, 262 NE2d 402, 407 (1970); Toalson v Madison, 307 SW2d 32, 34-35 (Mo Ct App 1957); Beacon Homes, Inc. $v$ Holt, 266 NC 467, 146 SE2d 434, 439 (1966); Jensen v Probert, 174 Or 143, 148 P2d 248, 252-53 (1944); Citizens \& Southern Natl Bank v Modern Homes Constr. Co., 248 SC 130, 149 SE2d 326, 328 (1966); Sequatchie Coal Co. $v$ Sunshine Coal \& Coke Co., 25 Tenn App 604, 166 SW2d 402, 404 (1942); Salazar v Garcia, 232 SW2d 685, 689 (Tex Civ App 1950); Somerville v Jacobs, $153 \mathrm{~W}$ Va 613,170 SE2d 805, 813 (1969).

$2 \times$ See, for example, Posey $v$ Owens, 504 S2d 299, 301 (Ala Civ App 1986) (claimed improver cleared a 20-acre parcel with bulldozer); Crouch v Crouch, 244 Ark 823, 431 SW2d 261, 265 (1968) (clearing 160 acres in wooded area for golf course); McIntosh $v$ Borchers, 201 Neb 35, 266 NW2d 200, 202-03 (1978) (Improvements on 160-acre farm included "removing trees and brush, leveling land."); Uhlhorn v Keltner, 723 SW2d 131, 
nessee case involved the mistaken occupant of a 360-acre "marshy swamp," described as "totally unsuited for cultivation" but "a hunter's and fisherman's paradise." ${ }^{\text {"286 }}$ Before learning of his error, the occupant spent over $\$ 180,000$ to drain and "clear[ ] the land of timber and undergrowth" so as to permit farming. ${ }^{287}$ The reviewing court had "no doubt" that this action was a "permanent improvement" that merited compensation. ${ }^{288} \mathrm{~A}$ parallel group of decisions reimburses the mistaken improver who builds a cabin or other structure in a wilderness region. ${ }^{289}$ In one remarkable decision, mistaken occupants on forty acres of national forest land, who cleared vegetation and built structures, were allowed to recover as good faith improvers. ${ }^{290}$

The modern good faith-improver doctrine facilitates needless injury to wilderness areas. Suppose $K$ elects to preserve her fivehundred-acre forest tract in natural condition. $L$, under the mistaken belief that he owns the property, plans to clear the land, sell the timber, and establish a farm. If $L$ is aware of the good faith-improver doctrine, its potential cushion may tend to deflect reexamination of his title. Conversely, if wilderness destruction were not compensable, putative owners like $L$ would presumably be more careful. Existing law, however, protects the negligent

134, 137 (Tenn Ct App 1986) (Claimed improver on 360-acre parcel of "marshy swamp ... cleared the land of timber and undergrowth."). See also Pamlico County $v$ Davis, 249 NC 648, 107 SE2d 306, 309 (1959) (clearing an abandoned farm tract described as "an old piece of waste-land laid out, and grown up"). But see Knoll v Delta Development Co., 218 S2d 109, 110, 114 (La Ct App 1969) (In rejecting the claim of a supposed improver who cleared 24.5 acres of "unimproved, wooded land," the court reasoned that although the cleared land "has a higher market value now than it had before these clearing operations were conducted," it "was not necessary to conduct these operations for the preservation of the land, [and] the owners did not wish that the land be cleared.").

${ }^{286}$ Uhlhorn, 723 SW2d at 134.

287 Id at $134-35$.

${ }^{289}$ Id at 137. See also State v Taylor, 368 SE2d 601, 602 (NC 1988) (reversing on sovereign immunity grounds trial court's $\$ 300,000$ award for "improvements" to unsuccessful title claimant who erroneously cleared 157 acres of state-owned North Carolina forest land for cultivation).

289 For examples of mistaken improvements found reimbursable by the courts, see Raab v Casper, 51 Cal App 3d 866, 124 Cal Rptr 590, 592 (1975) (cabin on 20-acre "foothill" tract bearing pine and manzanita trees); Agliato $v$ Norton, 632 A2d 144, 145 (Me 1993) (cabin on parcel of lakefront property); Hogerheide $v$ Hickey, 2 Mich App 580, 141 NW2d 357, 359-60 (1966) (home on lot near lake); Snadon v Gayer, 566 SW2d 483, 494-95 (Mo Ct App 1978) (home on 10-acre tract "covered with second growth mostly and ... a swampy area"). Compare Worley $v$ Ehret, 36 Ill App 3d 48, 343 NE2d 237, 239 (1976) (clubhouse and other structures on part of 70-acre tract of land that was not "tillable"); Madrid v Spears, 250 F2d 51, 55 (10th Cir 1957) (unspecified improvements on 320 acres of land "in its raw state").

${ }_{200}$ United States v Hato Rey Building Co., 660 F Supp 1340, 1348-49 (D PR 1987). 
despoiler. Thus, if $L$ destroys the forest in good faith, and thereby increases the market value of $K$ 's land, two results follow. First, $K$ is barred from collecting damages for the degradation that $L$ caused; as a result, her financial ability to restore the land is impaired ${ }^{291}$ Second, adding insult to injury, $K$ is forced to pay $L$ for $L$ 's negligent destruction of the land $K$ wished to preserve; depending on $K$ s financial condition, this expense may imperil her ability to preserve the rest of her property.

\section{Land-use disputes between neighbors.}

a. Trespass. The nineteenth-century "free-range" standard, which permits livestock to trespass on unfenced land, still affects most privately owned wild grassland and rangeland. ${ }^{292}$ Modern free-range jurisdictions often blunt the impact of the rule somewhat by allowing individual counties to enact "herd laws" that reinstate the common law-liability rule; this practice generally results in a statewide patchwork of divergent standards, with the free-range rule predominating in rural areas. ${ }^{293}$

201 This analysis assumes, of course, that the property owner would be entitled to compensatory damages for trespass. Yet because natural vegetation has little or no cognizable market value, in many instances no damages would be awarded in the first instance. See, for example, Boswell v Roy O. Martin Lumber Co., 355 S2d 33, 38 (La Ct App 1978) (Cutting of timber on fifty acres of "unimproved swampy land," "used for no purpose other than for squirrel hunting," did not diminish the land's value.); Foster v Beard, 221 S2d 319, 322 (La Ct App 1969) ('Plaintiffs' desire that the character of the property not be ... changed from woodland to open, agxicultural land constitutes no basis for the allowance of damages.").

202 Most remaining "grassland pasture and range," including land of wilderness quality, is located in the western United States. See Daugherty, Major Uses of Land at 10 table 9 (cited in note 199) (noting that the Mountain and Pacific areas contain 354.3 million acres of such land, which constitutes 60 percent of the total 588.8 million acres in the continental United States). Most western states follow the free-range rule in one form or another, as do a few states in other regions. See State $v$ Gallagher, 169 Ariz 202, 818 P2d 187, 189 (Ct App 1991); Williams v River Lakes Ranch Development Corp, 41 Cal App 3d 496, 116 Cal Rptr 200, 205 (1974); State v Moldovan, 842 P2d 220, 225-26 (Colo 1992); Easley $v$ Lee, 111 Idaho 115, 721 P2d 215, 217-18 (1986); Martin v Finley, 227 Mont 242, 738 P2d 497, 499 (1987); Fuchser $v$ Jacobson, 205 Neb 786, 290 NW2d 449, 451-52 (1980); Hollingsworth $v$ King, 810 SW2d 772, 775-76 (Tex Ct App 1991); Holly Hill Farm Corp v Rowe, 241 Va 425, 404 SE2d 48, 48 (1991); Kenney $v$ Walla Walla County, 45 Wash App 861, 728 P2d 1066, 1068 (1986); R.O. Corp v John H. Bell Iron Mountain Ranch Co., 781 P2d 910, 912 (Wyo 1989). Compare Bryant v McCann, 297 S2d 262, 265 (La Ct App 1974) (noting that portions of Louisiana are "open range" areas).

${ }^{203}$ Even highly populated California reflects a hodgepodge of standards. The freerange rule continues to apply in all of Lassen, Modoc, and Siskiyou counties, as well as in portions of Shasta and Trinity counties. See Cal Food \& Agric Code $\S \S 17123,17125-26$ (West 1986). Moreover, the board of supervisors of each county may declare by ordinance that all or part of its county is "devoted chiefly to grazing," and thus is subject to the freerange rule. Cal Food \& Agric Code $\S 17124$ (West 1986). For a useful study of the impact 
Moreover, although willful livestock trespassing is now routinely prohibited, the rule is weakly enforced. ${ }^{294}$ Most courts, acknowledging that unfenced livestock are likely to trespass, ${ }^{295}$ have proven reluctant to find willful conduct absent extreme circumstances. In one case, a New Mexico man pastured cattle on his own unfenced land, which apparently did not offer enough fodder; inevitably, the hungry cattle wandered onto his neighbor's 320 acre parcel of "unfenced grazing land" and caused substantial damage. ${ }^{296}$ The state supreme court suggested that even if the cattle owner was aware that his land "did not have sufficient grass ... to pasture his animals," and that they would inevitably stray onto plaintiff's land in order to survive, this would not constitute willful trespass. ${ }^{297}$ Similarly, in another case, a cattle owner who allowed his stock to continue trespassing on 1,280 acres of Wyoming grassland, even after the property owner complained, was found not liable for willful trespass. ${ }^{298}$

In effect, then, the free-range rule remains dominant in the regions most vulnerable to environmental damage from grazing-remote grassland and rangeland wilderness. This standard permits grazing that imperils the ecological integrity of such land in several respects, including regional elimination of plant species, ${ }^{299}$ accelerated erosion, ${ }^{300}$ and increased soil aridity. ${ }^{301}$

that these free-range provisions have had in Shasta County, California, see Ellickson, 38 Stan L Rev 623 (cited in note 180).

${ }^{294}$ See, for example, Montgomery $v$ Gehring, 145 Mont 278, 400 P2d 403, 406 (1965) (Owner of livestock "is under no duty to restrain them from entering another's unenclosed land ... through following their natural instincts," absent "wilful or intentional herding or driving of livestock onto another's unfenced land or placing them so near that trespass is bound to occur.").

${ }_{295}$ See, for example, Holland Livestock Ranch $v$ United States, 714 F2d 90, 92 (9th Cir 1983) (noting that unenclosed cattle are likely to trespass because "cows do not read plat books and are, accordingly, wholly indifferent to the law of trespass"); R.O. Corp, 781 P2d at 911 ("You can't tell a cow where to go and where not to go.").

296 Kinsolving $v$ Reed, 74 NM 284, 393 P2d 20, 20 (1964).

297 Id.

298 R.O. Corp., $781 \mathrm{P} 2 \mathrm{~d}$ at 911-12.

${ }^{299}$ See, for example, David T. Cox, Note, Deterioration of Southern Arizona's Grasslands: Effects of New Federal Legislation Concerning Public Grazing Lands, 20 Ariz L Rev $697,703-10$ (1978) (describing the manner in which overgrazing transformed the character of vegetation in southern Arizona from native grasses to shrublike vegetation); Goudie, Human Impact at 34-36 (cited in note 205) (discussing how overgrazing has altered the natural mix of grassland plants in portions of the western United States); 16th CEQ Report at 52 (cited in note 2) (noting that one historical impact of overgrazing public lands was a serious reduction of vegetation).

${ }^{300}$ See, for example, White Mountain Apache Tribe of Arizona $v$ United States, $11 \mathrm{Cl}$ Ct 614, 654 (1987) ("[O]vergrazing can change the character of the range, making it more susceptible to the erosive forces of nature, such as wind and rain."); 16th CEQ Report at 
Suppose $M$, the owner of one thousand acres of prairie grassland, elects to preserve the natural condition of her land. $N$, the owner of an adjacent five-hundred-acre unfenced tract, pastures cattle on his land, aware that the cattle will inevitably stray onto $M$ s land and damage it to some extent. In states recognizing the freerange rule, $M$ has no legal remedy; in effect, $N$ is empowered to destroy $M$ s land over her objection. ${ }^{302}$ In similar fashion, a preservationist Nebraska owner, who sought to establish a wildlife habitat program on his unfenced land covered with "natural growth," discovered that he had no recourse against the destruction caused by his neighbor's trespassing cattle. ${ }^{303}$

b. Nuisance. Nuisance law still embodies the nineteenthcentury locality focus that disparages wilderness preservation. The character of the locality remains a central criterion in determining whether a nuisance exists. ${ }^{304}$ Modern nuisance doctrine uses a hierarchy of protected land types in evaluating the significance of locality; wilderness land is the least protected category.

52 (cited in note 2) (noting impact of overgrazing on soil erosion in grassland areas); Joseph M. Feller, What is Wrong with the BLM's Management of Livestock Grazing on the Public Lands?, 30 Idaho L Rev 555, 561 (1994) (commenting that overgrazing "may decrease the ground cover necessary to prevent excessive erosion of soils by wind and rain").

${ }^{301}$ See White Mountain Apache Tribe, $11 \mathrm{Cl} \mathrm{Ct}$ at 654 (discussing expert testimony that the effects of overgrazing in rangeland areas included "increasing the aridity of the soil, and decreasing rainwater penetration of the soil"). See also Feller, 30 Idaho L Rev at 561 (cited in note 300 ) (commenting that overgrazing "decreases the ability of the land to absorb and hold water, thus causing accelerated surface runoff, increased flooding, and transformation of perennial streams into intermittent ones").

${ }^{302}$ Alternatively, $M$ might be able to protect her lands through fencing. Thus, one can view the free-range rule as allocating the burden to fence away from the livestock owner and onto other landowners. See Ronald H. Coase, The Problem of Social Cost, $3 \mathrm{~J} \mathrm{~L} \mathrm{\&}$ Econ 1, 2-3 (1960). Because $M$ derives no economic return from preservation, however, she may not be able to absorb the cost of establishing and maintaining an effective fence line. In the hypothetical described above, she would be forced to build and maintain over five miles of fence.

${ }^{303}$ Channer $v$ Tomlinson, 1993 Neb App LEXIS 33, *6-8.

304 As the Michigan Supreme Court has explained:

Nothing in the law of nuisance is better settled than this rule; that the locality and surroundings of the challenged operation or thing become an important factor in arriving at proper judicial decision of existence or non-existence of an actionable nuisance. That which would be actionable or abatable in one place or locality might not be such in another.

Obrecht v National Gypsum Co., 361 Mich 399, 105 NW2d 143, 151 (1960). See also Racine v Glendale Shooting Club, Inc., 755 SW2d 369, 372 (Mo Ct App 1988) (noting that "locality" and "character of neighborhood" are elements in nuisance determination). 
The Restatement (Second) of Torts recites the general rule that a private nuisance will be found whenever a defendant intentionally and unreasonably invades another's interest in the private use and enjoyment of his land. ${ }^{305}$ The key variable in this formula is unreasonableness, which is determined by balancing the gravity of the harm suffered by the plaintiff against the utility of the defendant's conduct. ${ }^{306}$ The suitability of each party's conduct to the "character of the locality" is an important factor in assessing both gravity and utility. ${ }^{307}$ Accordingly, the Restatement provides that an intentional invasion is unreasonable if it produces significant harm, the plaintiff's use is "well suited to the character of the locality," and the defendant's conduct is "unsuited to the character of the locality." 308

Human population density is the cornerstone of the locality hierarchy. A use that is a nuisance in an urban setting often will not be a nuisance in a sparsely populated countryside. ${ }^{309}$ In a recent Illinois decision, for example, homeowners in a rural farming region, described by the court as "quiet, peaceful, and beautiful, with much wildlife," sued to enjoin the operation of a sand and gravel strip mine; plaintiffs claimed that the mine, inter alia, destroyed vegetation and polluted a nearby river. ${ }^{310}$ Observing that "the suitability of the location to defendant's activity" required consideration, the court concluded that the mine was not a nuisance, in part because it was "operating in a suitable area, surrounded primarily by farmland."

Similarly, as the handful of relevant cases suggests, ${ }^{312}$ a

${ }^{305}$ Restatement (Second) of Torts $\$ 822$ (1979).

${ }_{306}$ Id $\S 826(a)$.

307 Id $\S \S 827(d), 828(b)$.

308 Id $\S 831$.

${ }^{309}$ The most frequently cited expression of this principle stems from Village of Euclid $v$ Ambler Realty Co., 272 US 365, 388 (1926): "A nuisance may be merely a right thing in the wrong place,-like a pig in the parlor instead of the barnyard." See also Pasulka $v$ Koob, 170 IIl App 3d 191, 524 NE2d 1227, 1231, 1239 (1988) (sand and gravel strip mine not a nuisance in rural area, characterized by "a large number of trees and wildlife" and farmland, because it was "operating in a suitable area"); York $v$ Stallings, 217 Or 13, 341 P2d 529, 533 (1959) (holding that in light of the "semi-rural" character of the area in question, operation of sawmill, which emitted smoke, cinders, and other particulates and thereby damaged plaintiff's 320 -acre farm, was not a nuisance, but observing that if the area had been "purely residential," rather than "semi-rural," then "very strict rules" would have been applied).

310 Pasulka, 524 NE2d at 1231, 1233.

311 Id at 1238-39.

312 See, for example, Ryan $v$ Pitkin Iron Corp, 444 F2d 717 (10th Cir 1971) (holding that proposed trailer camp for miners and related sewage disposal system on national forest land would not necessarily be a nuisance); Belue $v$ State, 199 Mont 451, 649 P2d 752, 
particular use which would be a nuisance in rural countryside is less likely to be deemed a nuisance in an unpopulated wilderness area. The Restatement expressly acknowledges its antiwilderness bent in a passage frequently cited by American courts: ${ }^{313}$

Life in organized society and especially in populous communities involves an unavoidable clash of individual interests. Practically all human activities unless carried on in a wilderness interfere to some extent with others or involve some risk of interference. ${ }^{314}$

Modern nuisance law logically encourages the placement of nuisance activities in wilderness regions. Suppose $O$ is a prospective widget manufacturer who must decide whether to locate her new factory in either a wilderness region or a sparsely populated farm region. All other factors being equal, the risk of nuisance liability in the farm region ${ }^{315}$ will cause $O$ to select the wilderness location. $O$ 's resulting land-clearing activity will destroy the environmental value of the factory site.

Moreover, beyond this site-specific impact, the factory will tend to erode the wilderness qualities of the surrounding area. Suppose that during normal operation $O$ 's factory emits smoke, noise, and light onto an adjacent one-thousand-acre parcel owned by $P$, who has voluntarily elected to preserve his land in natural

754 (1982) (burning slag pile in forest/rangeland area held not nuisance); Wildlife Preserves, Inc. $v$ Poole, 84 NJ Super 159, 201 A2d 377, 378-79 (1964) (filling of 9 acres of "swampland" adjacent to plaintiff's 1,500-acre fresh water marshland preserve held not nuisance); Green Acres Land \& Cattle Co. v State, 766 SW2d 649, $651-52$ (Mo Ct App 1988) (state's operation of 13,000-acre wildlife preservation area, which resulted in waterfowl destroying 6,000 acres of plaintiff's crops held not nuisance). But see Richardson $v$ Murphy, 198 Or 640, 259 P2d 116, 123-24 (1953) (holding that dump adjacent to plaintiff's 930-acre parcel of "forest land" was a fire hazard and hence a nuisance); Obrecht, $105 \mathrm{NW2d}$ at 151-52 (holding that dock, used for loading gypsum rock onto ships, located in region of lakefront "cottages and homes" in a "beautifully wooded sector," interfered with residents' enjoyment of their properties and thus was a nuisance, and observing that the defendant "ha[d] moved an otherwise lawful industrial operation into an area constituting the wrong place for it").

${ }^{313}$ See, for example, Carpenter $v$ Double $R$ Cattle Co., 105 Idaho 320, 669 P2d 643, 656 (Ct App 1983) (quoting Restatement); Watts $v$ Pama Manufacturing Co., 256 NC 611, 124 SE2d 809, 815 (1962) (same); Krueger $v$ Mitchell, 106 Wis 2d 450, 317 NW2d 155, 160 n 4 (Ct App 1982) (same); Peneschi $v$ National Steel Corp, 170 W Va 511, 295 SE2d 1, 5 (1982) ("[U]sing explosives in the midst of a city may be an absolute nuisance whereas in a wilderness it is not."). See also W. Page Keeton, ed, Prosser and Keeton on the Law of Torts 629 (West 5th ed 1984) (quoting Restatement).

314 Restatement (Second) of Torts $\$ 822$ comment g (1979).

${ }^{315}$ See, for example, Boomer v Atlantic Cement Co., 26 NY2d 219, 309 NYS2d 312 (1970) (upholding damage award to owners of farmland injured by smoke and dust emitted by cement plant). 
condition. These emissions will disrupt the ecosystems on $P$ 's land to some extent. The smoke may damage the native vegetation; $^{316}$ the noise and light may drive away wildlife, ${ }^{317}$ one of the key monitors of wilderness quality, ${ }^{318}$ which may in turn alter the soil and vegetation mantle. ${ }^{319} P$ may have no recourse against $O$ on a nuisance claim because $O$ 's activity is "suited" to a wilderness locality and thus has not caused $P$ the quality of harm that the law deems significant.

\section{TOWARD A NEW EQUILIBRIUM: WILDERNESS AND PROPERTY LAW IN THE TWENTY-FIRST CENTURY}

\section{A. An Anachronistic Bias}

American property law remains fundamentally hostile to wilderness preservation despite the changes wrought by two centuries. The nineteenth-century judicial impetus toward exploitation, while perhaps defensible in an era of wilderness abundance, is now both unnecessary and dangerous. The need to encourage wilderness development-the historic rationale for the antiwilderness bias-no longer exists in the United States. Moreover, this bias is anathema in a nation confronting wilderness scarcity; it imperils the contemporary movement toward voluntary preservation of privately owned wilderness land.

Two centuries of development have radically transformed our national attitude toward wilderness. ${ }^{320}$ For the pioneer, an ancient forest on future farmland had a negative value; it was an obstacle to be conquered before cultivation could begin. Wilderness preservation in such circumstances would have been economic and social heresy. Today, in contrast, our society values

${ }^{316}$ See Hendee, Stankey, and Lucas, Wilderness Management at 200 (cited in note 205); Goudie, Human Impact at 276-83 (cited in note 205).

${ }_{317}$ See, for example, Minnesota Pub Interest Research Group $v$ White Bear Rod and Gun Club, 257 NW2d 762, 774, 780 (Minn 1977) (upholding order closing gun club, relying in part on testimony that noise from shooting would "seriously affect" wild birds).

${ }^{318}$ See Hendee, Stankey, and Lucas, Wilderness Management at 218-19 (cited in note 205).

319 Id at 219.

320 The seminal study of American attitudes toward wilderness is Nash, Wilderness and the American Mind (cited in note 34). Other useful sources include Peter N. Carroll, Puritanism and the Wilderness: The Intellectual Significance of the New England Frontier 1629-1700 (Columbia 1969); Hans Huth, Nature and the American: Three Centuries of Changing Attitudes (Nebraska 1990); Peter J. Schmitt, Back to Nature: The Arcadian Myth in Urban America (Oxford 1969); and Henry Nash Smith, Virgin Land: The American West as Symbol and Myth (Harvard 1970). 
wilderness for both moral $^{321}$ and utilitarian ${ }^{322}$ réasons. A recent national survey, for example, found that-if forced to choose-Americans prefer environmental protection over economic development by a three-to-one margin. ${ }^{323}$ The same study revealed that most Americans believe the legal system has "not gone far enough" in protecting "wild or natural areas."

At the statutory level, the American legal system generally reflects a prowilderness orientation. As the Wilderness Act proclaims, "it is hereby declared to be the policy of the Congress to secure for the American people... the benefits of an enduring resource of wilderness. ${ }^{325}$ During the environmental law explosion of the last three decades, federal, state, and local legislative bodies have adopted an array of statutory provisions directed toward preserving the natural condition of public ${ }^{326}$ and private $^{327}$ lands.

321 I discuss the moral bases for valuing preservation in Sprankling, 79 Cornell $L$ Rev at 867-68 (cited in note 9). The principal modern exponent of moral duty in this context was Aldo Leopold, who argued for the development of a "land ethic" that would respect nonhuman species. See Leopold, Sand County Almanac at 219-20 (cited in note 222). Interestingly, a majority of Americans now agree that the preservation of other species is a "moral duty." See Times Mirror Magazines, Natural Resource Conservation: Where Environmentalism is Headed in the 1990s 62 (1992) ("Natural Resource Conservation") (noting that in the 1992 National Environmental Forum Survey, 63 percent of respondents agreed that "moral duty" was a "strong argument" in favor of protecting nonhuman species).

322 For a discussion of utilitarian bases for preservation, see Sprankling, 79 Cornell L Rev at 868-71 (cited in note 9). See also Frank B. Cross, Natural Resource Damage Valuation, 42 Vand L Rev 269, 280-97 (1989) (discussing preservation value, nonconsumptive use value, and consumptive use value of natural resources); John A. Dixon and Paul B. Sherman, Economics of Protected Areas: $A$ New Look at Benefits and Costs 24-49 (Island 1990) (generally exploring the economic values that wilderness preservation provides); Edith Brown Weiss, The Planetary Trust: Conservation and Intergenerational Equity, 11 Ecol L Q 495 (1984) (considering nonconsumptive use values in the natural resources context); Reed F. Noss, Comment, Sustainability and Wilderness, 5 Conservation Biology 120 (1991) (discussing rationales for wilderness preservation).

${ }^{323}$ Times Mirror Magazines, Natural Resource Conservation at 55 (cited in note 321) (Assuming that it "is impossible to find a reasonable compromise between economic development and environmental protection," 64 percent of respondents concluded that environmental protection was "more important," while only 17 percent opted for economic development.).

324 Id at 57 (Fifty-nine percent of respondents stated that "laws and regulations" had "not gone far enough" to protect wild or natural areas, while 27 percent felt that the "right balance" had been struck, and 7 percent responded that the legal system had "gone too far.").

${ }_{325} 16$ USC \$ 1131(a).

${ }^{326}$ See notes 212 and 216 (discussing formal programs to preserve government-owned lands in natural condition).

${ }^{327}$ A broad range of legislation is aimed at preserving the natural condition of privately owned lands. At the most basic level, a variety of local zoning statutes and ordinances are expressly directed toward this end. See, for example, Burrows $v$ City of Keene, $121 \mathrm{NH}$ 
But the foundation upon which these modern statutory additions rest-the two-hundred-year-old common law property system-continues essentially unaffected by the progressive prowilderness policy. ${ }^{328}$ It remains largely frozen in an antiwilderness bias that is increasingly out of step with the national consensus.

\section{B. Rebalancing Property Law}

Diagnosis is easier than cure. The antiwilderness bias is embedded too deeply in the structure of American property law to surrender without a lengthy and complex struggle. Moreover, given the range of property doctrines affected by this bias, an effective remedy must address the overall system, not merely individual rules.

The goal is simple: the basic orientation of property law must . shift from wilderness destruction to wilderness preservation. Just as the nineteenth-century instrumentalists retooled English property law to meet the challenge of wilderness abundance, modern neoinstrumentalist judges must transform American property law to contend with the problem of wilderness scarcity. In other words, the law should tend to resolve disputes concerning wilderness land by favoring the preserver over the exploiter.

\section{Wilderness land as a legal category.}

Over the course of two centuries, American courts created an

590,432 A2d 15, 17, 21 (1981) (observing that city zoned a 124-acre parcel of privately owned "undeveloped woodland" as open space because it wished the land to be preserved as a "wilderness area"); Dodd v Hood River County, 115 Or App 139, 836 P2d 1373 (1992) (upholding denial of permit to build single family house in forestry zone); Just $v$ Marinette County, 56 Wis 2d 7, 201 NW2d 761, 765-66 (1972) (involving wetland tract rezoned into conservancy district where use of land was restricted). See also Norman Williams, Jr. and John M. Taylor, 5 American Land Planning Law \$§ 158.23-158.35 at 460-515 (Callaghan rev ed 1985) (surveying local ordinances restricting development in forest, wetland, floodplain, and coastal areas). But see Lucas v South Carolina Coastal Council, 505 US 1003 (1992) (concluding that statute that effectively barred plaintiffs from constructing residences on their beachfront lots was a compensable taking, even though the statute was enacted, inter alia, to preserve the coastal beach and dune system). Even recreational immunity statutes have been interpreted as reflecting a legislative policy to preserve privately owned natural lands. See, for example, Keelen $v$ State, 463 S2d 1287, 1290 (La 1985) (noting that policy behind state recreational immunity statute was to encourage landowners to "keep their property in a natural, open and environmentally wholesome state").

${ }^{328}$ A number of states have statutorily modified the common law to facilitate private preservation efforts by legitimizing the use of conservation easements. See generally Diehl and Barrett, Conservation Easement Handbook (cited in note 226). 
implicit dichotomy between wilderness land and other types of real property. Regardless of the doctrinal window through which one gazes-waste, adverse possession, bona fide purchaser, good faith improver, trespass or nuisance-wilderness land receives notably less judicial protection than nonwilderness land. The first step toward redressing this imbalance is to explicitly acknowledge the distinction. Judicial opinions should expressly recognize two qualitatively different categories of privately owned real property: "wilderness land" and "developed land."

"Wilderness land" should be equated with de facto wilderness: ${ }^{329}$ forests, prairies, wetlands, deserts, and other private lands that essentially appear to be in primeval condition, without any noticeable human imprint. All other land-including residential property, industrial land, crop land, tree plantations, and other property bearing a significant human imprint-should be considered "developed land." Developed land is essentially a commodity, ${ }^{330}$ a commercial unit that has lost its wilderness value. ${ }^{331}$ Accordingly, it would remain subject to existing common law property doctrines. Wilderness land, however, would qualify for enhanced protection as a separate category of real property. ${ }^{332}$

329 See text accompanying notes 217-20.

330 In large part due to our historic wilderness surplus, Americans have tended to view land as a commodity, a fungible unit of commerce. See Richard F. Babcock and Duane A. Feurer, Land as a Commodity "Affected with a Public Interest", 52 Wash L Rev 289, 291-99 (1977) (discussing the history of the treatment of land as a commodity); Caldwell, $15 \mathrm{Wm}$ \& Mary L Rev at 761-62 (cited in note 7) (criticizing the tendency to view land as a commodity); Donald W. Large, This Land Is Whose Land? Changing Concepts of Land as Property, 1973 Wis L Rev 1039, 1043-45 (same). Compare Adolph A. Berle, Property, Production and Revolution, 65 Colum L Rev 1, 4 (1965) (dividing all property into two categories, either "productive property"-used for "production, manufacture, service[,] or commerce"-or "consumption property"-consumed by its ultimate user, such as a home, a car, or a household appliance).

331 Under the de facto wilderness standard, it is possible that "developed land," if abandoned, might ultimately be covered again by natural vegetation and thus qualify as "wilderness land." For example, "[t]hough little virgin forest remains in New England, the forest has regrown so completely that few hilkers realize that a trailside vista was once abusively cut and often burned." Lloyd C. Irland, Wildlands and Woodlots: The Story of New England's Forests 94 (U Press New England 1982). The regeneration period, however, is measured in generations, not years. As one court observed, "[a]s of today but few true wilderness areas remain. Once penetrated by civilization and man made activities, [wilderness] cannot be regained for perhaps hundreds of years. The recovery period is meaningless for generations to come. The destruction is irreversible." Izaak Walton League of America $v$ St. Clair, 353 F Supp 698, 714 (D Minn 1973).

332 A number of scholars have espoused varying property dichotomies, arguing that one type of property should receive heightened protection over another. See, for example, Margaret Jane Radin, Property and Personhood, 34 Stan L Rev 957, 978-1015 (1982) (suggesting enhanced protection for "personal property" as opposed to "fungible property"); Berle, 65 Colum L Rev at 4, 9-12 (cited in note 330) (discussing differences in protection 
2. A green thumb on the scales of justice.

A counterweight rights the imbalanced scale. The nineteenth-century judiciary disrupted the balance of property law with the weight of an antiwilderness thumb. In similar fashion, the judiciary of the twenty-first century should rebalance the scale with a preservation counterweight. In resolving disputes concerning the use or ownership of privately owned wilderness land, American courts should favor preservation over destruction. Thus, when dealing with a common law property doctrine demonstrably skewed by the antiwilderness bias, a court should apply the doctrine in a manner that compensates for the bias. All other factors being equal, then, courts should tend to disallow exploitative use or ownership.

Any systemic solution must be sufficiently broad and sufficiently flexible to guide judicial reconfiguration of diverse doctrines over a long transition period. Even as no single coat fits all persons, no single blueprint for change accommodates all property rules. ${ }^{333}$ Thus, the counterweight metaphor provides a conceptual framework, not a Procrustean mandate, to facilitate systemic reform on a case-by-case basis. Three examples, expanding on hypotheticals discussed earlier, illustrate how the counterweight approach would function.

First, consider how the doctrine of waste might be reformed as applied to wilderness land. Recall the waste hypothetical posed above: ${ }^{34} A$, holding a tenancy for years in a tract including two hundred acres of wild wetlands, proposes to clear the land for agriculture; assuming that $A$ 's actions will increase the market value of the land, $C$, holding the reversionary interest, cannot successfully sue $A$ in waste under the prevailing good husbandry standard. A modern court, aware that the doctrine remains infected by the antiwilderness bias, ${ }^{335}$ could modify the good husbandry standard by reexamining the comparative importance of development and preservation. Thus, a future court might abandon the market-based good husbandry test, and adopt in its place a "prudent preservation" standard for applying the

accorded to productive property and personal consumption property).

${ }^{333}$ For example, in Sprankling, 79 Cornell $L$ Rev at 862-84 (cited in note 9), I argue that privately owned "wild" lands should be immune to adverse possession. Although I find this absolutist solution appropriate for adverse possession, it cannot be universally applied to all doctrines involving wilderness land. See text accompanying notes 334-40.

334 See text accompanying note 248 .

335 See text accompanying notes 247-58. 
doctrine to wilderness land. In the hypothetical dispute between $A$ and $C, C$ s interest in preserving the natural condition of the land would normally prevail.$^{336}$ Other factors could, of course, overcome this preservation preference; the court might wish to consider the relative wilderness value of the land, the social value of $A$ 's planned crops, the likelihood that $C$ 's interest in the land will become possessory, and other similar criteria.

The good faith-improver doctrine could be similarly rebalanced. Consider the hypothetical discussed earlier: ${ }^{337} L$, negligently believing that he owns $K$ 's five-hundred-acre tract of forest wilderness, clears the land; if $L$ 's actions increase the market value of the property, the doctrine allows him to obtain compensation from $K$. In reconfiguring the doctrine, a contemporary court would decree that the good faith-improver rule presumptively does not apply to wilderness land. ${ }^{338}$ In the typical case, then, $K$ should owe $L$ nothing. Additional facts might overcome this presumption in other disputes. An owner might be held liable under the doctrine, for example, if the improver somehow enhanced the owner's ability to preserve his wilderness land ${ }^{339}$ or if the owner caused or contributed to the improver's error.

Finally, consider how the counterweight approach might affect the nuisance doctrine. In the nuisance hypothetical posited above ${ }^{340}$ widget entrepreneur $O$ builds her new factory in a wilderness area; the resulting emissions of smoke, noise, and light injure $P$ 's adjacent one-thousand-acre wilderness sanctuary. Under the balancing test espoused by the Restatement (Second) of Torts, the wilderness character of the locality tilts the scales toward the conclusion that $O$ 's conduct is reasonable and hence not a nuisance. Application of the preservation counterweight would transform wilderness locality into a criterion that augurs in favor of finding a nuisance. All other factors again being equal,

${ }^{336}$ Compare Knowles $v$ Moore, 622 SW2d 803, 804-05 (Mo Ct App 1981) (allowing owner of four hundred acres of "true prairie" covered with natural grasses to recover damages on waste claim against tenant who converted property into farmland).

${ }^{337}$ See text accompanying note 290.

338 Compare Knoll v Delta Development Co., 218 S2d 109, 110, 114 (La Ct App 1969) (refusing to award compensation to good faith improver who cleared 24.5 acres of "unimproved, wooded land," thereby enhancing its market value, where it "was not necessary to conduct these operations for the preservation of the land, [and] the owners did not wish that the land be cleared").

339 For example, the good faith improver might erect a perimeter fence that both causes no environmental injury and actually facilitates the owner's preservation goal by limiting access.

340 See text accompanying note 315 . 
the reformed nuisance standard would tend to protect, not injure, wilderness land.

Over time, judicial implementation of the counterweight approach would create a common law of wilderness preservation. ${ }^{341}$ The underlying orientation of the property law system would tend to favor preservation in resolving use and title disputes. Moreover, the resulting body of propreservation case law would provide public norms to facilitate wilderness protection outside of the dispute resolution context. ${ }^{342}$ As a result, the American property law system would slowly adjust to the environmental realities of the twenty-first century.

\section{CONCLUSION}

The American wilderness is still melting away like Marshall's metaphorical snowbank. For two centuries, the common law of property has actively encouraged this destruction through an inherent antiwilderness bias. Even today, the property law system typically adjudicates use and title disputes concerning privately owned wilderness by preferring exploitation to preservation. This antiwilderness orientation is a dangerous anachronism in an era of wilderness scarcity.

We must rebalance property law by establishing a propreservation equilibrium that facilitates voluntary preservation of wilderness land. The property law system of the twentyfirst century need not perpetuate the errors of the past.

31 I do not necessarily advocate the adoption of indeterminate "balancing" tests on a permanent basis. In general, indeterminate standards tend to undermine efficiency by increasing administrative costs. See Carol M. Rose, Crystals and Mud in Property Law, 40 Stan L Rev 577, 578 (1988) (characterizing "fuzzy, ambiguous rules of decision" as "mud" tests); Sprankling, 79 Cornell L Rev at 878-79 (cited in note 9) (discussing the increased litigation costs associated with indeterminate tests). In the short run, the rejection of existing bright-line doctrines skewed by the antiwilderness bias will cause confusion. I anticipate, however, that the reformulation of property doctrines in transitional cases will ultimately lead to new prowilderness rules of reasonable clarity.

${ }^{342}$ See generally Smith, 91 Colum L Rev at 72-73 (cited in note 245) (discussing the role of the rule of law in facilitating human interaction outside of the dispute resolution context). 